\title{
Exceptional skull of huayqueriana (mammalia, litopterna, macraucheniidae) from the late miocene of argentina: anatomy, systematics, and paleobiological implications
}

\author{
Forasiepi, Analia M ; MacPhee, R D E ; del Pino, Santiago Hernández ; Schmidt, Gabriela I ; Amson,
} Eli ; Grohé, Camille

\begin{abstract}
The Huayquerías Formation (Late Miocene, Huayquerian SALMA) is broadly exposed in westcentral Argentina (Mendoza). The target of several major paleontological expeditions in the first half of the 20th century, the Mendozan Huayquerías ("badlands") have recently yielded a significant number of new fossil finds. In this contribution we describe a complete skull (IANIGLA-PV 29) and place it systematically as Huayqueriana cf. H. cristata (Rovereto, 1914) (Litopterna, Macraucheniidae). The specimen shares some nonexclusive features with $\mathrm{H}$. cristata (similar size, rostral border of the orbit almost level with distal border of M3, convergence of maxillary bones at the level of the P3/P4 embrasure, flat snout, very protruding orbits, round outline of premaxillary area in palatal view, and small diastemata between I3/C and C/P1). Other differences (e.g., lack of sagittal crest) may or may not represent intraspecific variation. In addition to other features described here, endocast reconstruction utilizing computer tomography (CT) revealed the presence of a derived position of the orbitotemporal canal running below the rhinal fissure along the lateroventral aspect of the piriform lobe. CT scanning also established that the maxillary nerve (CN V2) leaves the skull through the sphenoorbital fissure, as in all other litopterns, a point previously contested for macraucheniids. The angle between the lateral semicircular canal and the plane of the base of the skull is about $26^{\circ}$, indicating that in life the head was oriented much as in modern horses. Depending on the variables used, estimates of the body mass of IANIGLA-PV 29 produced somewhat conflicting results. Our preferred body mass estimate is 250 $\mathrm{kg}$, based on the centroid size of 36 3D cranial landmarks and accompanying low prediction error. The advanced degree of tooth wear in IANIGLA-PV 29 implies that the individual died well into old age. However, a count of cementum lines on the sectioned left M2 is consistent with an age at death of 10 or 11 years, younger than expected given its body mass. This suggests that the animal had a very abrasive diet. Phylogenetic analysis failed to resolve the position of IANIGLA-PV 29 satisfactorily, a result possibly influenced by intraspecific variation. There is no decisive evidence for the proposition that Huayqueriana, or any other litoptern, were foregut fermenters.
\end{abstract}

DOI: https://doi.org/10.5531/sd.sp.23

Posted at the Zurich Open Repository and Archive, University of Zurich

ZORA URL: https://doi.org/10.5167/uzh-124755

Journal Article

Published Version

Originally published at: 
Forasiepi, Analia M; MacPhee, R D E; del Pino, Santiago Hernández; Schmidt, Gabriela I; Amson, Eli; Grohé, Camille (2016). Exceptional skull of huayqueriana (mammalia, litopterna, macraucheniidae) from the late miocene of argentina: anatomy, systematics, and paleobiological implications. Bulletin of the American Museum of Natural History:1-78.

DOI: https://doi.org/10.5531/sd.sp.23 
EXCEPTIONAL SKULL OF HUAYQUERIANA (MAMMALIA, LITOPTERNA, MACRAUCHENIIDAE)

FROM THE LATE MIOCENE OF ARGENTINA:

ANATOMY, SYSTEMATICS, AND PALEOBIOLOGICAL IMPLICATIONS

\author{
ANALÍA M. FORASIEPI, ROSS D.E. MACPHEE, \\ SANTIAGO HERNÁNDEZ DEL PINO, GABRIELA I. SCHMIDT, \\ ELI AMSON, AND CAMILLE GROHÉ
}

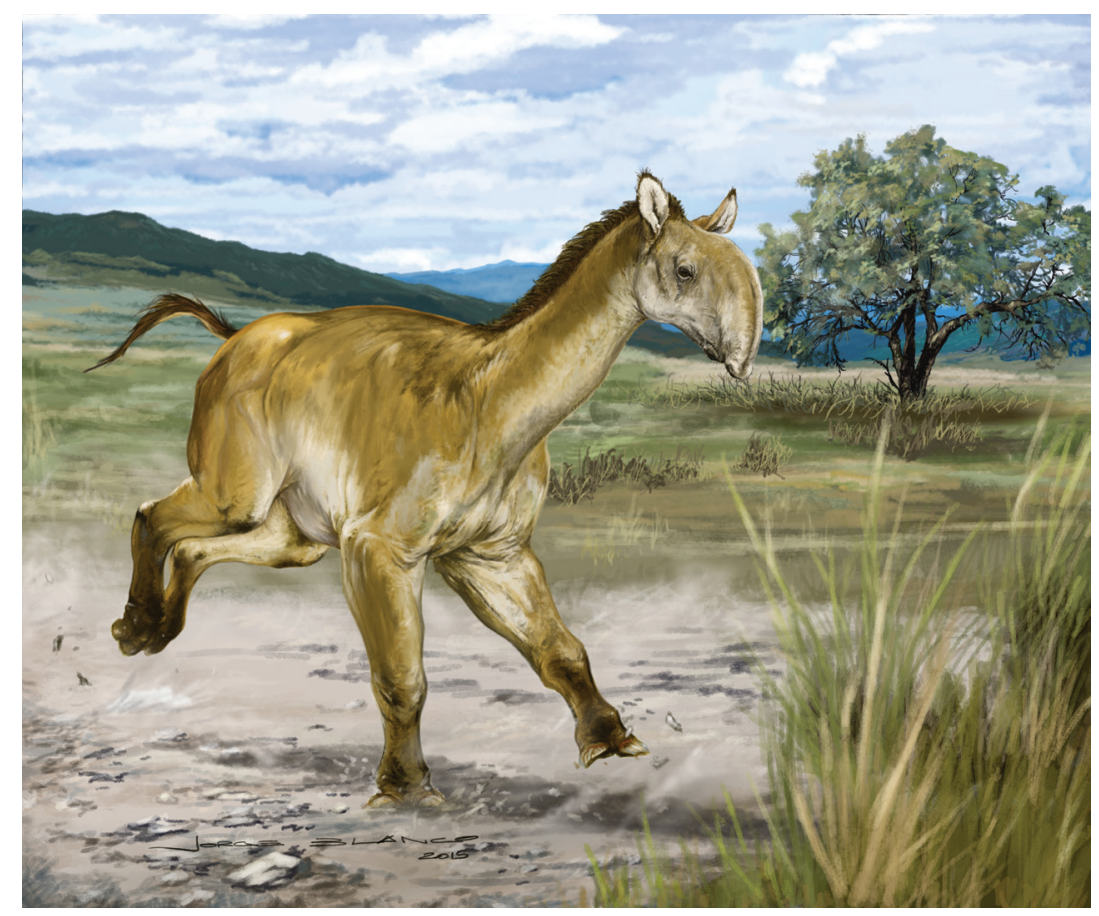

BULLETIN OF THE AMERICAN MUSEUM OF NATURAL HISTORY 


\title{
EXCEPTIONAL SKULL OF HUAYQUERIANA \\ (MAMMALIA, LITOPTERNA, MACRAUCHENIIDAE) \\ FROM THE LATE MIOCENE OF ARGENTINA: \\ ANATOMY, SYSTEMATICS, AND PALEOBIOLOGICAL \\ IMPLICATIONS
}

\author{
ANALÍA M. FORASIEPI \\ IANIGLA, CCT-Mendoza, CONICET \\ ROSS D. E. MACPHEE \\ Department of Mammalogy, American Museum of Natural History \\ SANTIAGO HERNÁNDEZ DEL PINO \\ IANIGLA, CCT-Mendoza, CONICET \\ GABRIELA I. SCHMIDT \\ Laboratorio de Paleontología de Vertebrados (CICYTTP-CONICET) \\ ELI AMSON \\ Paläontologisches Institut und Museum, Universität Zürich
}

CAMILLE GROHÉ

Department of Vertebrate Paleontology, American Museum of Natural History

BULLETIN OF THE AMERICAN MUSEUM OF NATURAL HISTORY

Number 404, 76 pp., 30 figures, 5 tables

Issued June 22, 2016 


\section{CONTENTS}

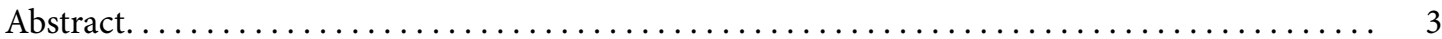

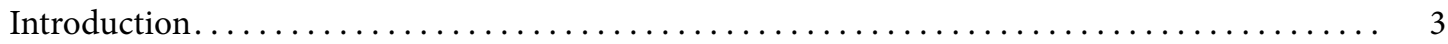

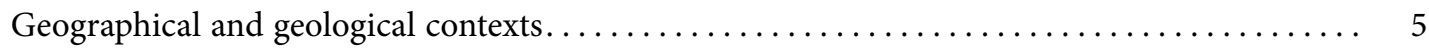

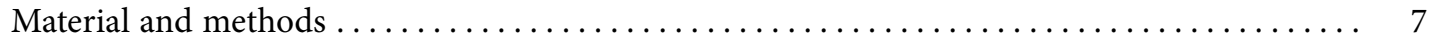

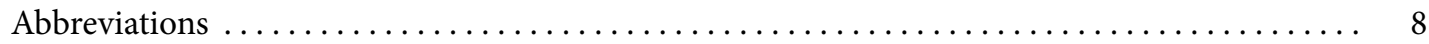

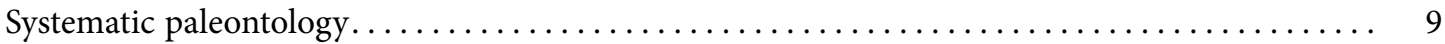

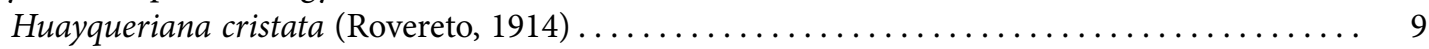

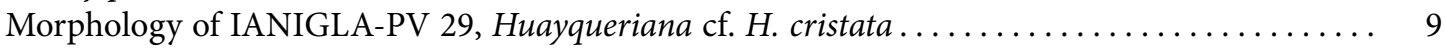

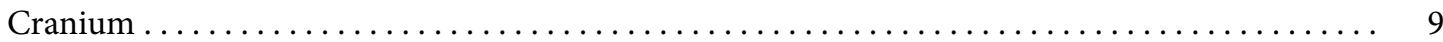

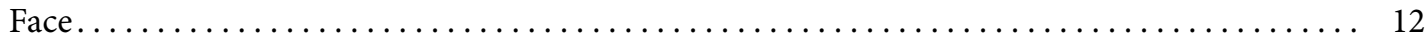

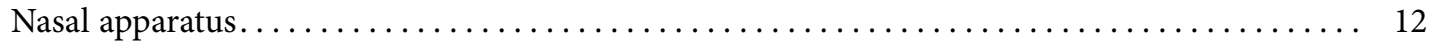

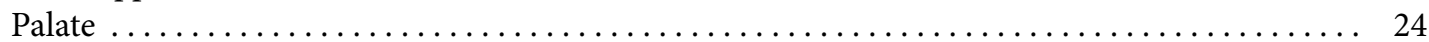

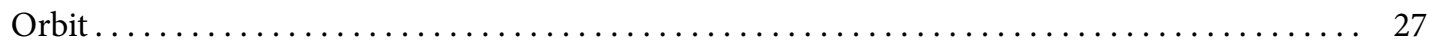

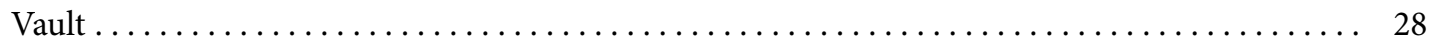

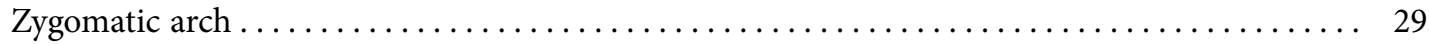

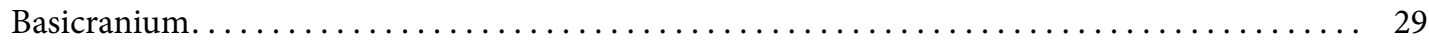

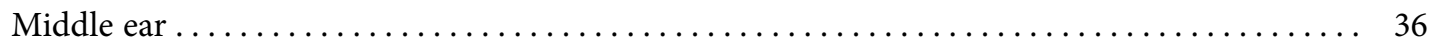

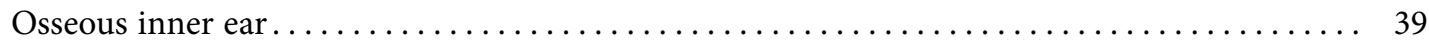

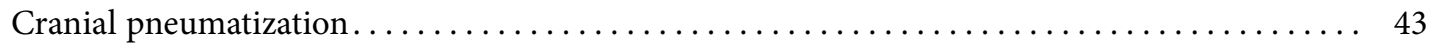

Cerebral endocast........................................ 44

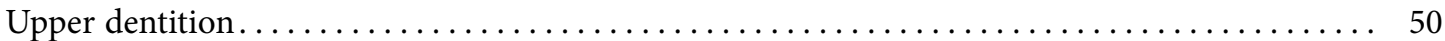

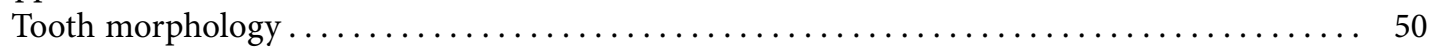

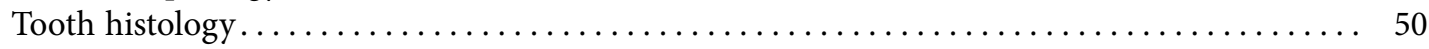

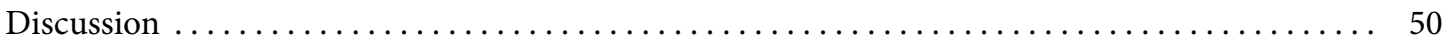

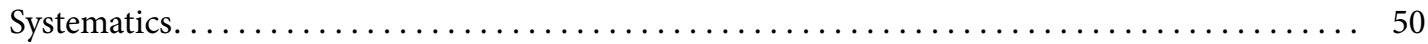

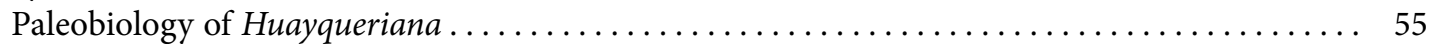

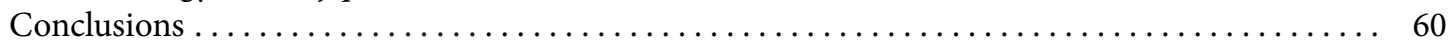

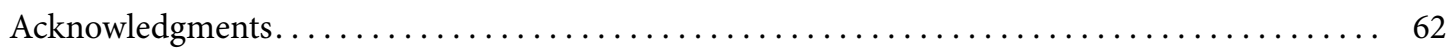

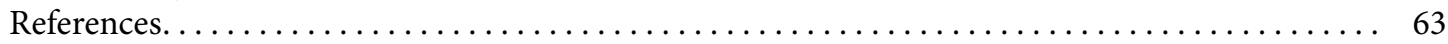

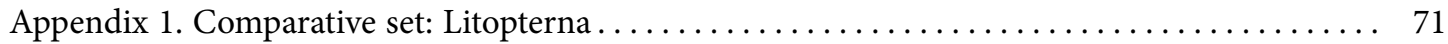

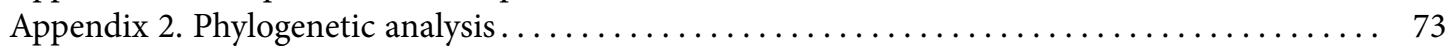

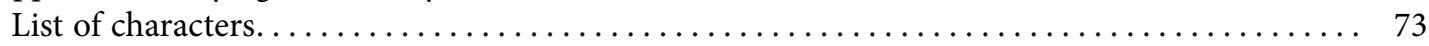

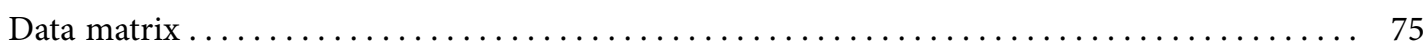

Appendix 3. Skull length and width of temporalis canal in hindgut and foregut fermenters ... 76 


\begin{abstract}
The Huayquerías Formation (Late Miocene, Huayquerian SALMA) is broadly exposed in westcentral Argentina (Mendoza). The target of several major paleontological expeditions in the first half of the 20th century, the Mendozan Huayquerías ("badlands") have recently yielded a significant number of new fossil finds. In this contribution we describe a complete skull (IANIGLA-PV 29) and place it systematically as Huayqueriana cf. H. cristata (Rovereto, 1914) (Litopterna, Macraucheniidae). The specimen shares some nonexclusive features with $H$. cristata (similar size, rostral border of the orbit almost level with distal border of M3, convergence of maxillary bones at the level of the $\mathrm{P} 3 / \mathrm{P} 4$ embrasure, flat snout, very protruding orbits, round outline of premaxillary area in palatal view, and small diastemata between $\mathrm{I} 3 / \mathrm{C}$ and $\mathrm{C} / \mathrm{P} 1$ ). Other differences (e.g., lack of sagittal crest) may or may not represent intraspecific variation. In addition to other features described here, endocast reconstruction utilizing computer tomography (CT) revealed the presence of a derived position of the orbitotemporal canal running below the rhinal fissure along the lateroventral aspect of the piriform lobe. CT scanning also established that the maxillary nerve $\left(\mathrm{CN} \mathrm{V}_{2}\right)$ leaves the skull through the sphenoorbital fissure, as in all other litopterns, a point previously contested for macraucheniids. The angle between the lateral semicircular canal and the plane of the base of the skull is about $26^{\circ}$, indicating that in life the head was oriented much as in modern horses. Depending on the variables used, estimates of the body mass of IANIGLA-PV 29 produced somewhat conflicting results. Our preferred body mass estimate is $250 \mathrm{~kg}$, based on the centroid size of $363 \mathrm{D}$ cranial landmarks and accompanying low prediction error. The advanced degree of tooth wear in IANIGLA-PV 29 implies that the individual died well into old age. However, a count of cementum lines on the sectioned left M2 is consistent with an age at death of 10 or 11 years, younger than expected given its body mass. This suggests that the animal had a very abrasive diet. Phylogenetic analysis failed to resolve the position of IANIGLA-PV 29 satisfactorily, a result possibly influenced by intraspecific variation. There is no decisive evidence for the proposition that Huayqueriana, or any other litoptern, were foregut fermenters.
\end{abstract}

\section{INTRODUCTION}

By any measure, the morphological diversification of South American native ungulates (SANUs) during the Cenozoic was extraordinary. In size alone, they ranged from notoungulates no larger than rabbits (e.g., Pachyrukhos, 2 $\mathrm{kg}$; Cassini et al., 2012a) to rhino-sized astrapotheres (e.g., Parastrapotherium, 2000 kg; Kramarz and Bond, 2008). In terms of taxonomic diversity, Notoungulata was the most successful of the SANU orders, followed by Litopterna with about a hundred species discriminated at present (Cifelli, 1983, 1993; Cifelli and Soria, 1983; Bond, 1986, 1999; Bond et al., 1995, 2001; Cifelli and Guerrero, 1997; Soria, 1981, 2001; Scherer et al., 2009; Schmidt and Ferrero, 2014). Nevertheless, despite their numerous morphological specializations, according to collagen proteomic studies these two SANUs not only appear to have shared a common ancestry but also are most closely related to Perissodactyla among major extant placental taxa (Welker et al., 2015; Buckley, 2015). The relationships of other major SANU clades to one another or to other placentals have not been resolved.

Several families have been classically incorporated within Litopterna. The central families arose at the end of the Oligocene and extensively radiated during the Neogene: Adianthidae (Late Oligocene-Early Miocene), Proterotheriidae (Late Oligocene-Late Pleistocene), and Macraucheniidae (Late Oligocene-Late Pleistocene/Early Holocene), the latter represented by Cramaucheniinae (including Theosodontinae) and Macraucheniinae (Cifelli, 1983; Bond, 1986, 1999; Soria, 1986, 2001; Schmidt and Ferrero, 2014). Various Paleogene groups (Amilnedwardsiidae, Anisolambdidae, Indalecidae, Notonychopidae, 
TABLE 1

Checklist of the family Macraucheniidae

\begin{tabular}{lll}
\hline \hline Cullinia levis & Cabrera and Kraglievich, 1931 & Late Miocene \\
Huayqueriana cristata & $\left(\right.$ Rovereto, 1914) ${ }^{1}$ & Late Miocene \\
Macrauchenia patachonica & Owen, 1838 & Quaternary \\
Macrauchenopsis ensenadensis & $\left(\right.$ Ameghino, 1888) ${ }^{2}$ & Quaternary \\
Oxyodontherium zeballosi & Ameghino, 1883a ${ }^{3}$ & Late Miocene \\
Paranauchenia hystata & $($ Cabrera and Kraglievich, 1931) & Late Miocene \\
Paranauchenia denticulata & (Ameghino, 1891a) & Late Miocene \\
Promacrauchenia antiquua & (Ameghino, 1887a) ${ }^{4}$ & Early Pliocene \\
Promacrauchenia calchaquiorum & Rovereto, 1914 & ?Late Miocene / \\
Promacrauchenia chapadmalense & & ?Early Pliocene \\
Promacrauchenia kraglievichi & Ameghino, 1908 & Early Pliocene \\
Promacrauchenia (Pseudomacrauchenia) yepesi & Karodi, 1931 & Early Pliocene \\
Scalabrinitherium bravardi & Ameghino, 1883b ${ }^{5}$ & Quaternary \\
Scalabrinitherium rusconi & Parodi, 1931 ${ }^{6}$ & Late Miocene \\
Windhausenia delacroixi & & ?Late Miocene / \\
Xenorhinotherium bahiense & Kraglievich, 1930 & ?Pliocene \\
\hline \hline
\end{tabular}

${ }^{1}$ Includes Macrauchenidia latidens Cabrera, 1939.

${ }^{2}$ Not certainly valid, may be part of Windhausenia (e.g., Marshall et al., 1984).

${ }^{3}$ Includes Mesorhinus Ameghino, 1885.

${ }^{4}$ See text fn. 1.

${ }^{5}$ Includes Scalabrinia Lydekker, 1894.

${ }^{6}$ Not certainly valid.

Protolipternidae, and Sparnotheriodontidae) are also frequently cited as true litopterns, but whether they actually belong in the same monophyletic group as the later taxa is debatable (Cifelli, 1993; Billet et al., 2015).

Macraucheniinae currently includes 16 species (table 1), some of which are based on isolated postcranial material and are of uncertain validity (e.g., Parodi, 1931; Kraglievich, 1930; Paula Couto, 1945). At least from the standpoint of taxonomic richness, peak diversity for this group was achieved in the Late Miocene, with some localities containing as many as five coeval species (e.g., Ituzaingó Formation; Schmidt and Cerdeño, 2013). Species richness on this scale may be regarded as due either to particularly intense selection and environmental exploitation by contemporaneous taxa, or to taxonomic inflation consequent on limited or noncomparable hypodigms.

The macraucheniine fossil record is comparatively good, particularly for the Pleistocene (Fernández de Álvarez, 1940). Macrauchenia patachonica, the first remains of which were recovered by Charles Darwin on January 9, 1834, at Puerto San Julian in Patagonia, was also the last member of the family to disappear, persisting in the Pampean region of Argentina into the Early Holocene $\left(8390 \pm 140{ }^{14} \mathrm{C}\right.$ yr BP; Tonni, 1990; Bond, 1999).

Macraucheniines were long-necked, horsesized herbivores, possibly cursorial with threedigit cheiridia. In this subfamily the molars are encased in cementum and mesodont, with deeper enamel fossettes than in other macraucheniids (e.g., Cramauchenia, Theosodon) (Bond, 1999). 
This tooth morphology probably evolved to cope with the hard parts of xerophytic plants (e.g., thick foliar cuticles and spines, fruits encased in hard shells or rinds to combat desiccation; Villagra et al., 2011) typical of the dry, open environments that became the rule in much of southern South America as a consequence of Late Miocene climate change. Decreasing global temperatures, together with greater seasonality, aridity, and the spread of C4 grasslands (Cerling et al., 1997; Zachos et al., 2001) were correlated with an increase in the diversity and abundance of mammals with hypsodont teeth (Jernvall and Fortelius, 2002; Eronen et al., 2010). Hypsodonty is particularly marked in the South American mammal record from the mid-Paleogene onward (Madden, 2015). Euhypsodonty (= elodonty; ever-growing, open-rooted teeth) is very widespread in Late Miocene herbivores (e.g., sloths, armadillos, glyptodonts, notoungulates, and many caviomorph rodents), although litopterns, unlike notoungulates, never developed this adaptation. On the basis of measurements of the temporal fossa in Theosodon, Madden (2015) has hypothesized that at least some macraucheniids may have been foregut fermenters, like artiodactyl ruminants. However, the evidence is not persuasive (see Digestive Physiology).

One of the most characteristic features of the macraucheniine skull is the repositioning of the nasal aperture. Instead of being situated at the front of the face, below the orbits and immediately above the incisors, the aperture is situated in a centrodorsal position, between the eyes, near the morphological summit of the skull. Although it has long been assumed that this highly derived positioning implies the existence of a trunk or similar appendage (Burmeister, 1864; Scott, 1937; Rusconi, 1957; Soria, 1981; Bond, 1999), detailed comparative anatomical evaluations in support of this inference are lacking.

In this contribution, we provide a detailed comparative description of an exceptionally wellpreserved skull of Huayqueriana cf. $H$. cristata (IANIGLA-PV 29) from the Late Miocene Huayquerías Formation, Mendoza, Argentina, utilizing both traditional methods of description as well as micro-CT scanning. We additionally evaluate species taxonomy, phylogenetic relationships, and paleobiological parameters such as body mass, longevity, and digestive physiology.

\section{GEOGRAPHICAL AND GEOLOGICAL CONTEXTS}

The huayquerías, or badlands, of central Mendoza (fig. 1A) have yielded fossils of a wide range of mammalian taxa generally regarded as Late Miocene-Pliocene in age (Marshall et al., 1986; Yrigoyen, 1994). Paleontological studies in the area were initiated in the first half of the 20th century and have continued on an irregular basis since then (De Carles, 1911; Rovereto, 1914; Frenguelli, 1930; Rusconi, 1939; Marshall et al., 1986; Forasiepi et al., 2014, 2015a).

The Huayquerías del Este (Eastern Badlands) present three outcropping formations. These include a Late Miocene unit, (1) the Huayquerías Formation, and two Pliocene units, (2) the Tunuyán and (3) the Bajada Grande formations (Dessanti, 1946; Marshall et al., 1986; Yrigoyen, 1993, 1994). The Huayquerías del Este are dominated by a large, extensively faulted anticline, in the central portion of which the eponymous Huayquerías Formation outcrops (to avoid possible confusion between geographical and formational names, the Huayquerías Formation will hereafter be abbreviated to HF). The HF is $\sim 200$ $\mathrm{m}$ thick (Marshall et al., 1986) and is composed of massive beds of brownish-grey sandstones with sporadic intercalations of red mudstones (fig. 1B; Dessanti, 1946; Marshall et al., 1986), deposited in an alluvial environment with ephemeral rivers and muddy floodplains (Garrido et al., in prep.; Forasiepi et al., 2015a).

A fourth unit, the Tobas Angostura Formation, does not outcrop in the study area but does so farther north. Yrigoyen (1993) inferred that this unit, which has an estimated age of 10.5-9.5 $\mathrm{Ma}$ on the basis of K/Ar dating, must immediately underlie the HF. If that inference is correct, the base of the HF cannot be much less than the 


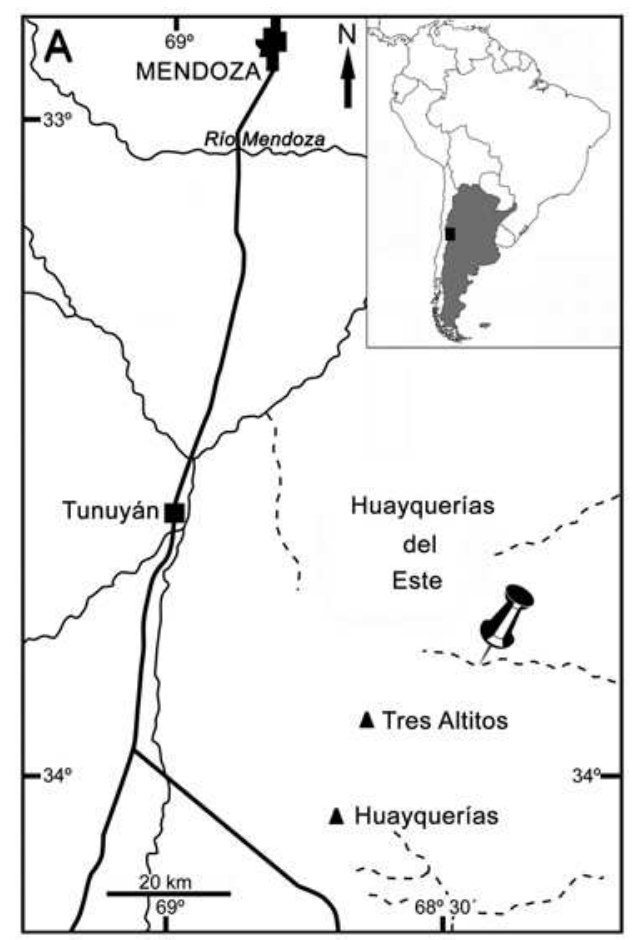

\section{B}
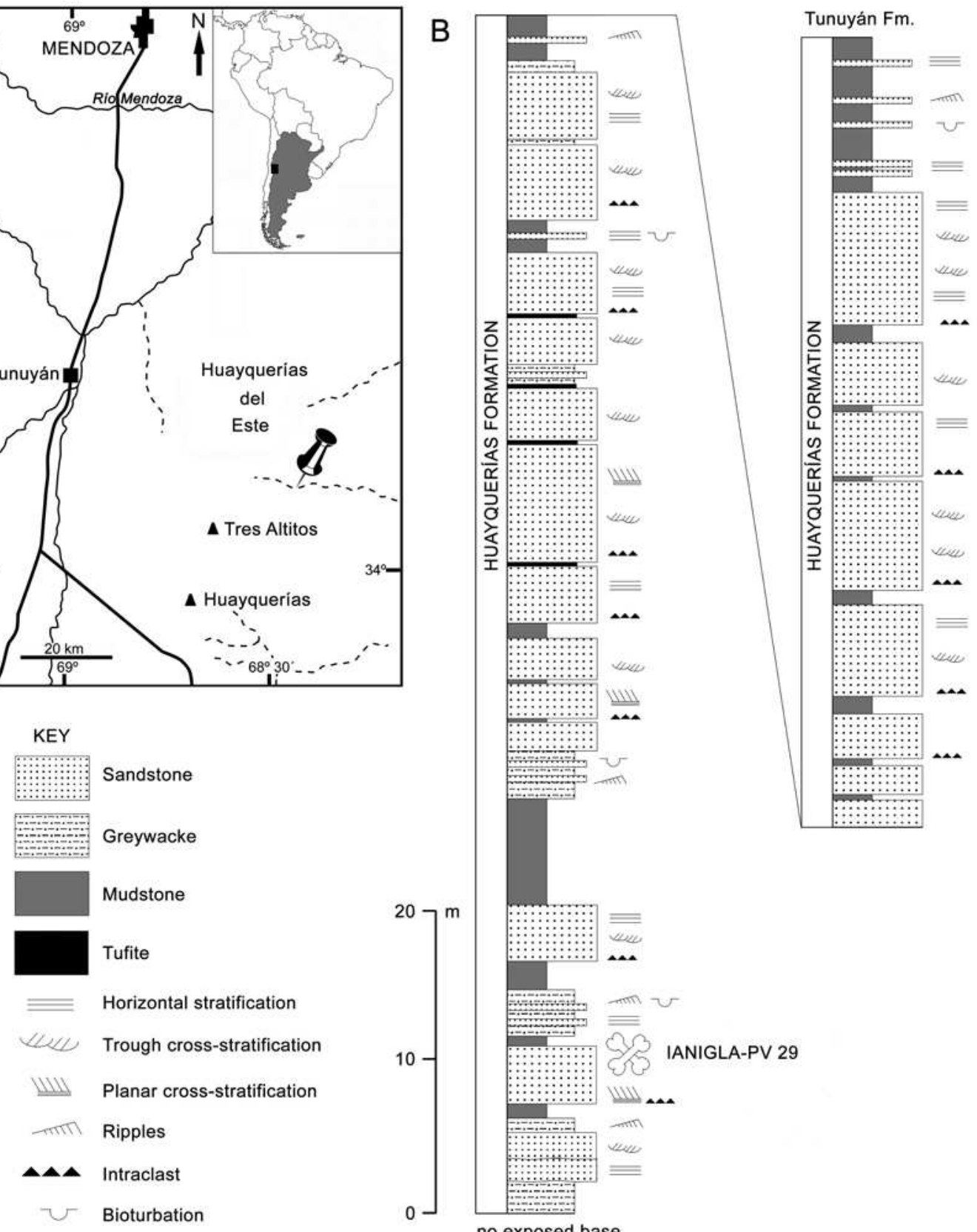

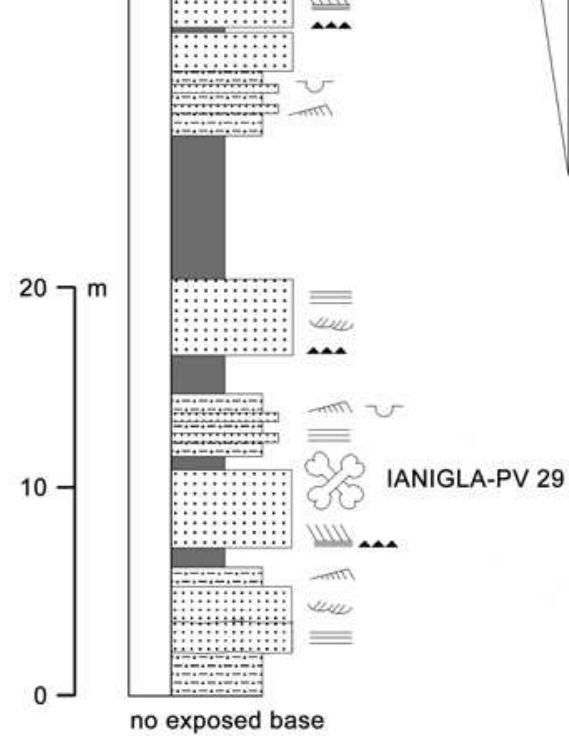

FIG. 1. Geographical and stratigraphic context: A, location of Río Seco de la Última Aguada, north-central Mendoza, Argentina; B, integrated stratigraphic column, Río Seco de la Última Aguada, Huayquerías del Este. Huayqueriana cf. H. cristata IANIGLA-PV 29 was recovered from lower levels of Huayquerías Formation (Late Miocene; Huayquerian) exposed along river gorge. 
indicated range. The top of the HF was estimated to be approximately 5.8 Ma by Yrigoyen (1994) on the basis of K/Ar dates reported by Marshall et al. (1986). However, because of uncertainties concerning the stratigraphic extent and definition of the overlying Tunuyán Formation (Garrido et al., in prep.), this estimate has to be treated with caution.

The Huayquerian South American Land Mammal Age (SALMA) was originally defined on the basis of a small series of mammal taxa from HF as then understood (Kraglievich, 1934; Simpson, 1940). The original faunal list included Megatheriops rectidens (Megatheriidae), Proscelidodon gracillimus (Mylodontidae), Hemihegetotherium achataleptum (Hegetotheriinae), Neobrachytherium sp. (Proterotheriidae), Huayqueriana cristata (Macraucheniidae), Cyonasua pascuali (Procyonidae), and Lagostomus pretrichodactyla (Chinchillidae) (Rovereto, 1914; Rusconi, 1939; Kraglievich and Olazábal, 1959; Linares, 1981; Marshall et al., 1983; Pascual and de la Fuente, 1993; Soria, 2001). It is important to note that Huayquerian age assignments have frequently been made for Neotropical mammal associations recovered from a wide variety of other contexts throughout South America, such as Urumaco in Venezuela (Linares, 2004) and Acre in Brazil (Cozzuol, 2006; Ribeiro et al., 2013). This also applies to the correlation of presumed age-equivalent stratigraphic units, such as the Cerro Azul and Epecuén Formations in the Pampean area (Goin et al., 2000; Montalvo et al., 2008; Verzi et al., 2011), the Chiquimil or Andalhuala formations in northwestern Argentina (e.g., Reguero and Candela, 2011; see also Esteban et al., 2014, for a discussion on the topic and references herein cited). However, it should be noted that the evidence for some of these faunal and temporal correlations with the Huayquerian SALMA as presently understood is notably slim.

Since 2013, new field work has been conducted in the HF in order to more fully characterize its actual faunal content, and thus lay a basis for a critical reassessment of the definition of the Huayquerian SALMA. Results to date include the first fossil footprints of a SANU (aff. Macrauchenichnus isp.) to be identified in this formation, as well as a notable expansion of the faunal list from the original seven taxa to $20+$ (including additional mammal, reptile and anuran taxa currently under study; Forasiepi et al., 2014, 2015a).

Among our fossil discoveries is the subject of this paper, IANIGLA-PV 29, a beautifully preserved skull here referred to Huayqueriana $\mathrm{cf}$. $H$. cristata. This specimen was collected from the HF sediments forming the floor of the Río Seco de la Última Aguada $\left(68^{\circ} 27^{\prime} 31.6^{\prime \prime} \mathrm{W}\right.$, $\left.33^{\circ} 54^{\prime} 14.5^{\prime \prime} \mathrm{S}\right)$, on the southeast side of the Huayquerías del Este (fig. 1B). According to De Carles (1911), the holotype of Huayqueriana cristata (MACN-PV 8463; fig. 2) was collected in the Huayquerías de Biluco, in the vicinity of Agua de la Concha at the foot of Cerro Torrecitas. This raises an interesting biostratigraphic issue, because the Tunuyán (nominally Pliocene) and the Huayquerías (nominally Late Miocene) formations both outcrop in this area (Yrigoyen, 1994). In addition, the sediment associated with MACN-PV 8463, a tuffaceous sandstone with fine-grained, immature epiclasts formed by quartz, hornblende, and other inclusions that react strongly to $\mathrm{HCl}$, is more reminiscent of the Tunuyán Formation than the HF (A.C. Garrido, personal commun., 2015).

\section{MATERIAL AND METHODS}

Descriptions of IANIGLA-PV 29 in the following pages are grouped by region: cranium (face, orbit, vault, zygoma, basicranium), cerebral endocast, and upper dentition. Anatomical terminology generally conforms to, or is adapted from, nomina recognized in Terminologia Anatomica (e.g., Schaller, 1992); for more specialized terms, we utilized MacPhee $(1981,2014)$ for the caudal cranium, Soria (2001) for the dentition, and Macrini et al. (2007a, 2007b) for the cerebral endocast. The description of the inner ear assumes that the lateral semicircular canal is oriented horizontally and centrally within the surrounding 
array of anatomical structures (Graf and Klam, 2006; Ekdale, 2013). Comparisons to other macraucheniids are based on direct study of specimens as well as descriptions and illustrations in the literature (appendix 1). Museum collection numbers are provided in the text when more than one individual is known for a single taxon.

In view of recent proteomic evidence for the close relationship of litopterns and notoungulates to Perissodactyla (Welker et al., 2015; Buckley, 2015), we make specific comparisons to living horses, tapirs, and rhinos where warranted. However, our primary purpose here is to investigate the relationships of Huayqueriana within the context of Litopterna, not to test the likelihood of Panperissodactyla (Welker et al., 2015) from the standpoint of cranial morphology.

Segmental data on Huayqueriana cf. H. cristata IANIGLA-PV 29 and Tetramerorhinus lucarius AMNH 9245 were collected with the GE Phoenix vtomex s240 $\mu \mathrm{CT}$ scanner housed at AMNH. The skull of Huayqueriana was scanned at $180 \mathrm{kV}, 220 \mathrm{~mA}$, with a voxel size of 124.06 $\mu \mathrm{m}$. The scan resulted in a final stack of 3585 slices of $1619 \times 1166$ pxl. The program 3DSlicer (open source http://www.slicer.org/; Fedorov et al., 2012) was used for $3 \mathrm{D}$ reconstruction and segmentation of the skull, endocast, and associated structures. Mimics 18.0 (Materialise NV, Leuven, Belgium) was used for 3D reconstruction of the petrosal and VGStudio MAX (Volume Graphics GmbH, Heidelberg, Germany) for the osseous inner ear. Linear and volumetric measurements of the endocast were calculated with 3D Slicer following standard dimensions proposed by Macrini et al. (2007b); angular measurements were calculated with the program ImageJ; linear measurements of the bony labyrinth were calculated with Mimics following the protocole of Schmelzle et al. (2007) for the dimensions of the semicircular canals. Height and width of the cochlea were measured in profile.

The left M2 of IANIGLA-PV 29 was extracted, embedded in Araldite epoxy resin, and prepared for histological study by cutting (1) a coronal section, at the level of the interroot pad where the cementum is usually the thickest, and (2) a paraocclusal section, in the distal root, apical to the crown. Cut surfaces were polished with $\mathrm{Al}_{2} \mathrm{O}_{3}$ sandpapers with successively smaller grit sizes $(320$ to 25,000$)$. The polished surfaces were lightly coated with glycerine, and observed with a stereoscopic microscope (Leica MZ $16^{\circ}$ ) under natural light. Images were taken with a Leica DFC $420 \mathrm{C}^{\circ}$ digital camera, and their contrast was enhanced with Adobe Photoshop'. For comparative purposes, the M1 of Theosodon garrettorum (PIMUZ A/V 4662) was subjected to the same procedure.

Phylogenetic relationships were explored via a cladistic analysis employing TNT (Goloboff et al., 2008). The data matrix is a modified version of that published by Schmidt and Ferrero (2014).

The body mass of IANIGLA-PV 29 was estimated using a variety of allometric equations in the literature that are in turn based on dental and cranial traits of extant euungulates (Artiodactyla and Perissodactyla) (see Body Size). Of general interest is our finding that body mass estimators based on cranial measurements were more plausible than ones based on teeth (cf. Cassini et al., 2012b).

\section{ABBREVIATIONS}

Institutional: AMNH, American Museum of Natural History, New York. IANIGLA-PV, Instituto Argentino de Nivología, Glaciología y Ciencias Ambientales, Vertebrate Paleontology, Mendoza, Argentina. MACN, Museo Argentino de Ciencias Naturales "Bernardino Rivadavia" (A, Ameghino; PV, Vertebrate Paleontology; SC Santa Cruz collections), Buenos Aires, Argentina. MHIN-UNSL-GEO-V, Museo de Historia Natural, Departamento de Geología of the Universidad Nacional de San Luis, Paleontological Collection, San Luis, Argentina. MLP, Museo de La Plata, Buenos Aires, Argentina. MPEF-PV, Museo Paleontológico "Egidio Feruglio," Trelew, Chubut, Argentina. NMB, Naturhistorisches Museum Basel, Switzerland. PIMUZ, Paläontologisches Institut und Museum, Universität Zürich, Switzerland; ZMUZH, Zoologisches Museum der Universität Zürich, Switzerland. 
Anatomical: Abbreviations used in individual figures, most of which are set in lowercase, are indicted in captions. In the main text, we use additional conventions. Upper teeth are capitalized while mandibular teeth are in lowercase, as follows: $\mathrm{C} / \mathrm{c}$, canine, $\mathrm{I} / \mathrm{i}$ incisor; $\mathrm{M} / \mathrm{m}$, molar; and $\mathrm{P} / \mathrm{p}$, premolar; $\mathrm{D} / \mathrm{d}$, deciduous dentition. For the petrosal, we capitalize the following abbreviations: IAM, internal acoustic meatus; CTPP, caudal tympanic process of the petrosal; FAI, inferior acoustic foramen; FAS, superior acoustic foramen, RTPP, rostral tympanic process of petrosal; SIPS, sulcus for the inferior petrosal sinus. For the inner ear: ASC, anterior semicircular canal; LSC, lateral semicircular canal; PSC, posterior semicircular canal; L, left; R, right.

Other abBreviations: CI, consistency index; RI, retention index; TBR, tree bisection reconnection.

\section{SYSTEMATIC PALEONTOLOGY}

Order Litopterna Ameghino, 1889

FAMILY Macraucheniidae Gervais, 1855

Subfamily Macraucheniinae Gervais, 1855

Huayqueriana Kraglievich, 1934

Huayqueriana Kraglievich, 1934: 117 (as subge-

nus of Promacrauchenia).

Huayqueria Riggs and Patterson, 1939: 157 (lapsus calami).

Macrauchenidia Cabrera, 1939: 167

Type species: Promacrauchenia? cristata Rovereto, 1914.

Huayqueriana cristata (Rovereto, 1914)

Promacrauchenia? cristata Rovereto, 1914: 212-

213; pl. 29, figs. 4, 4a.

Promacrauchenia (Huayqueriana) cristata Kra-

glievich, 1934: 117.

Huayqueria [sic] cristata Riggs and Patterson, 1939: 157.

Macrauchenidia latidens Cabrera, 1939: 167:

33-34, fig. 24; Pascual, 1966, pl. 71, figs. D and $\mathrm{E}$.

Huayqueriana cristata Soria, 1986: 158.
Holotype: MACN-PV 8463 (fig. 2), fragmentary skull and associated dentaries.

Huayqueriana cf. H. cristata (Rovereto, 1914)

REFERRED SPECIMEN: IANIGLA-PV 29, cranium with LP1-3, distal half of LP4, RP2-4, and R/ LM2-3 (figs. 3, 4, 10-22, 24-25, 27-28; tables 2-4).

GEOGRAPHIC AND STRATIGRAPHIC DISTRIBUTION: Huayquerías del Este, Río Seco de la Última Aguada $\left(68^{\circ} 27^{\prime} 31.6^{\prime \prime} \mathrm{W}, 33^{\circ} 54^{\prime} 14.5^{\prime \prime} \mathrm{S}\right)$, San Carlos Department, Mendoza Province, Argentina (fig. 1A). Huayquerías Formation (fig. 1B), Huayquerian SALMA (currently correlated with Tortonian-Messinian stages of Late Miocene; Marshall et al., 1986; Yrigoyen, 1994).

\section{MORPHOLOGY OF IANIGLA-PV 29, HUAYQUERIANA CF. H. CRISTATA}

\section{Cranium}

The skull is long, narrow, and low (fig. 3A). In overall size the specimen is similar to the holotype of Huayqueriana cristata (fig. 2), Promacrauchenia antiquua, ${ }^{1}$ Promacrauchenia calchaquiorum, and some specimens of Scalabrinitherium bravardi (e.g., MACN-A 1270); overall it is slightly larger than Oxyodontherium zeballosi, but smaller than Windhausenia delacroixi, Macrauchenia patachonica, and Xenorhinotherium bahiense (table 2; fig. 4). Most cranial elements are completely fused, with sutures obliterated; muscular scars are deep and teeth are heavily worn. Several teeth were lost during life, as indicated by bony infill within alveoli. These features strongly indicate that IANIGLA-PV 29 was a senile individual when it died (see Longevity). Although tooth wear is a proximate indicator of senescence (Skogland, 1988; Loe et al., 2003), wear rate will depend on dietary regime.

\footnotetext{
${ }^{1}$ Ameghino (1887a) described Macrauchenia antiqua as a new species from the Montehermosan of Buenos Aires. Since the trivial name is not spelled "antigua," the modern Spanish spelling of the cognate Latin fem. sing. adj. "antiquua," we infer that Ameghino's intention was clear but that he inadvertently substituted the former for the latter. Under the provisions of ICZN art. 33.2, we emend this name to Promacrauchenia (= Macrauchenia) antiquua.
} 


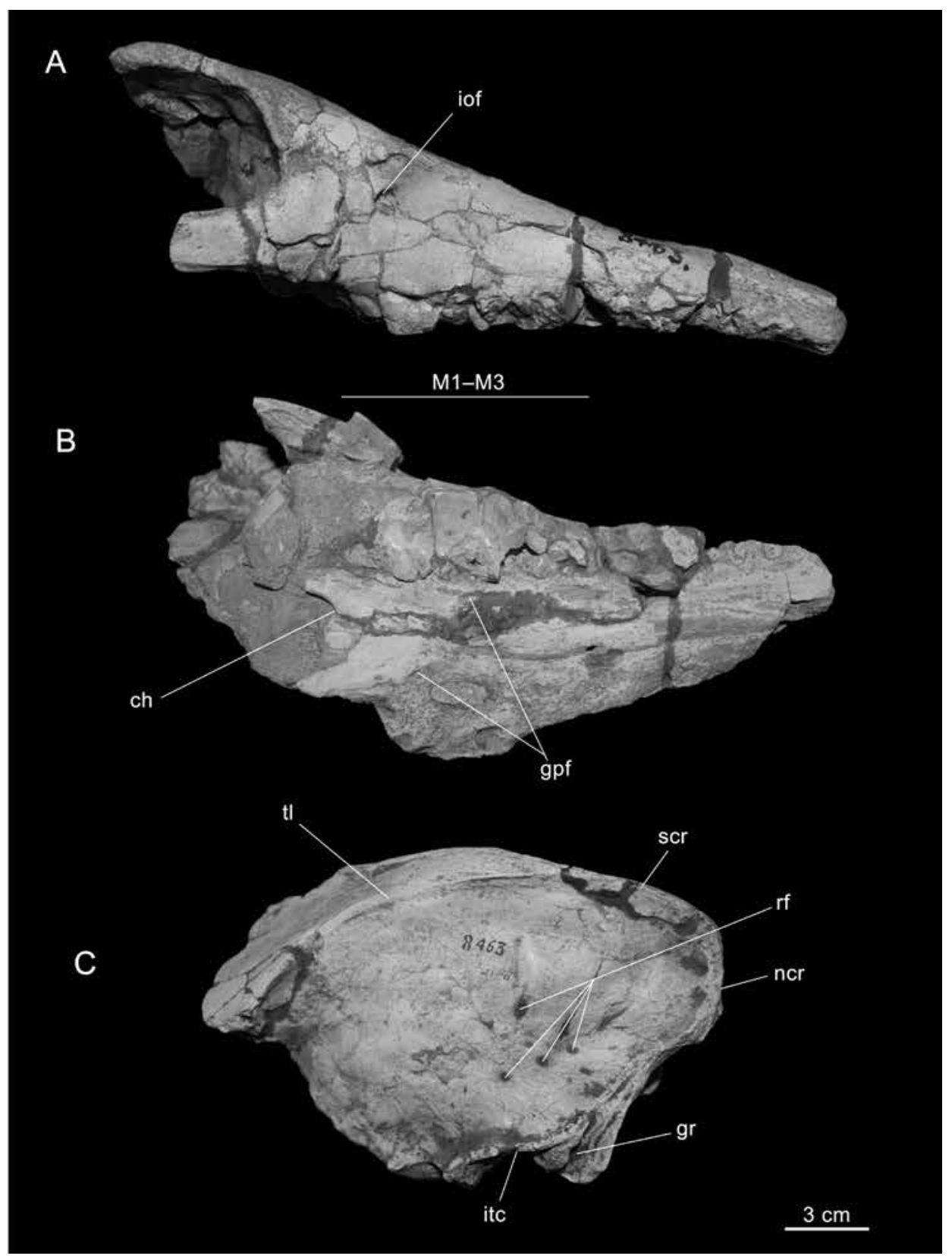

FIG. 2. Holotype of Huayqueriana cristata MACN-PV 8463 referred to Huayquerías Formation (Late Miocene, Huayquerian SALMA). A, right lateral and B, ventral views of snout; C, portion of braincase in left lateral view. Abbreviations: ch, choana; gpf, greater (= major) palatine foramen; gr, occipital groove; iof, infraorbital foramen; itc, infratemporal crest; $\mathbf{M}$, molar; ncr, nuchal crest; rf, foramina for rami temporales; scr, sagittal crest; tl, temporal line. 

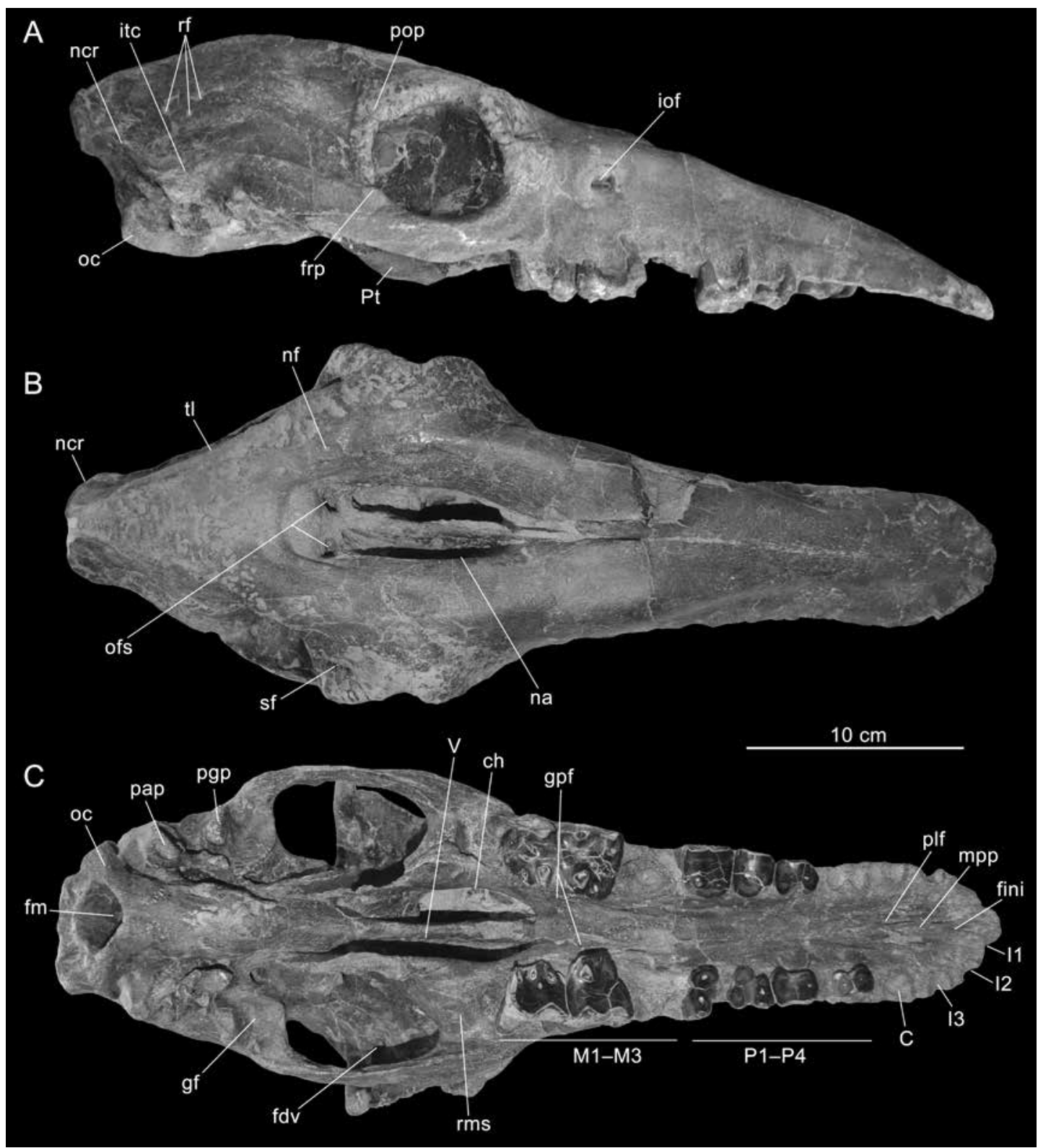

FIG. 3. Skull of Huayqueriana cf. H. cristata IANIGLA-PV 29 from Huayquerías Formation (Late Miocene, Huayquerian SALMA) in A, right lateral, B, dorsal, and C, ventral views. Abbreviations: C, canine (alveolus); ch, choana; fdv, foramen for frontal diploic vein; fini, foramen interincisivum; fm, foramen magnum; frp, frontal process of squamosal; gf, glenoid fossa; gpf, greater (= major) palatine foramen; I, incisor (alveolus); iof, infraorbital foramen; itc, infratemporal crest; $\mathbf{M}$, molar; mpp, medial palatine process of premaxilla; na, nasal aperture; ncr, nuchal crest; nf, nutrient foramina; oc, occipital condyle; ofs, openings of frontal sinus; P, premolar; pap, paracondylar process of exoccipital; pgp, postglenoid process; plf, palatine fissure; pop, postorbital process of frontal; Pt, pterygoid; rf, foramina for rami temporales; rms, retromolar space; sf, supraorbital foramen; tl, temporal line; $\mathbf{V}$, vomer. 
Taphonomically, some elements of the cranium were broken or lost during burial, and the skull has suffered slight dorsolateral compression.

\section{FACE}

In lateral view, the narrow snout gradually increases in height from front to back (fig. 3A), much as in Pr. antiquua and Pr. calchaquiorum. The bone comprising the rostralmost part of the snout is very slightly ventrally curved, a feature also seen in Pr. antiquua (fig. 5B) and possibly the holotype of $H$. cristata (fig. 2A). Curvature is slightly more pronounced in $H$. cristata (MLP 41-IV-29-4; 5A), O. zeballosi (MACN-PV 13671; MHIN-UNSL-GEO-V 465a, fig. 8A), and Pr. calchaquiorum (fig. 5C), whereas in $S$. bravardi (MACN-A 1270), M. patachonica, and X. bahiense the equivalent area is planar.

The premaxilla/maxilla sutures are obliterated, and maxillae are partially fused midsagittally (fig. 3B). The roughly circular infraorbital foramen is large ( $\sim 7 \mathrm{~mm}$ maximum diameter, compared to foramen ovale, $3.5 \mathrm{~mm}$ ). This implies, although does not prove, that the parts of the face supplied by local neurosensory $(\mathrm{CN}$ $\mathrm{V}_{2}$ ) and vascular bundles (infraorbital artery and vein) passing through the infraorbital foramen may have been of significant size, such as external nasal structures. The foramen opens dorsal to the transverse level of the distal part of M2 (fig. $3 \mathrm{~A}$ ), as in $H$. cristata (fig. 2A), Pr. antiquua (fig. 5B), Pr. calchaquiorum (fig. 5C), Paranauchenia denticulata, and $X$. bahiense (Cartelle and Lessa, 1988; Schmidt and Ferrero, 2014). The infraorbital foramen is positioned slightly more rostrally in O. zeballosi (MACN-PV 13671) where it opens above the M1/M2 embrasure; in MACNPV 8903 (referred to S. bravardi), it is situated at the level of the mesial part of M2. By contrast, it is slightly more caudal in $M$. patachonica (right side of the skull MACN-PV 2; MLP 12-1424 and 12-1425), where it opens at the level of the M3 (left side of the skull MACN-PV 2 exhibits two infraorbital foramina, one at the level of the M2 and the other at the level of the M3). In IANIGLA-PV 29, the maxillary foramen (caudal opening of the infraorbital canal) is of large size and compressed against the zygomatic arch.

The peculiar series of small sulci that issue from the infraorbital foramina, strongly marking both sides of the snout in specimens of $M$. patachonica (e.g., Burmeister, 1864), are also seen in Pr. antiquua MACN-PV 7986 (one only on each side), but are absent in Pr. calchaquiorum, MACN-PV 5528, and IANIGLA-PV 29. The face of Scalabrinitherium is missing and thus cannot be evaluated. The peculiarity of these sulci arises from the fact that, in M. patachonica, some of them actually overlap or cut through one another. They also seem to end blindly, with no reentry foramina within the maxilla. This suggests that their contents (presumably cutaneous nerves and associated blood vessels) were directed outward, toward large soft tissue targets in the face and snout.

\section{Nasal Apparatus}

The outstanding feature of IANIGLA-PV 29 in dorsal view (fig. 3B) is the enormous nasal aperture, framed by the hypertrophied maxillae laterally and the diminutive nasals caudally. The aperture is situated near the center of the cranial roof, as in other macraucheniines (figs. 6, 8). The sloping margins of the aperture open directly into the relatively large choanae except caudally, where there is a low bony shelf flanked by two symmetrically positioned openings, as in Pr. calchaquiorum MACN-PV 5528 (fig. 6C) and S. bravardi MACN-PV 13082 (fig. 9B). In IANIGLA-PV 29 these openings represent adituses into the paranasal frontal sinuses (fig. 11) (see Pneumatization). In the other fossils we assume conditions were similar, although we cannot confirm this because the equivalent area is either damaged or not fully prepared.

Dorsally, the caudal border of the nasal aperture intersects a line joining the caudal borders of the orbits, as in other macraucheniines (Soria, 1986). In dorsal view, in general outline the nasal aperture is roughly teardrop shaped, widest between the orbits and gradually tapering rostrally to a point at which the two maxillary bones converge at the level of the P3/P4 embrasure (fig. 
TABLE 2

Huayqueriana cristata (holotype, MACN-PV 8463) and Huayqueriana cf. H. cristata (IANIGLA-PV 29): Cranial and dental measurements (in $\mathrm{mm})^{1,2,3}$

Skull

(1) Skull, total length (TSL)

MACN-PV 8463

IANIGLA-PV 29

(2) Skull rostrum, length from tip of premaxilla to posterior border of orbit

(3) Skull vault, length

300

(4) Skull, width at level of zygomatic arches

(5) Face, depth below ventral rim of orbit (SD)

(6) Zygomatic arch, maximum height at level of orbit

112.04

(7) Orbit, length

18.15

(8) Orbit, height

50.93

57.34

(9) Frontal, width at level of postorbital processes

153.9

(10) Nasal aperture, maximum width

30.13

(11) Nasal aperture, maximum length

145.01

(12) Muzzle, maximum width (MZW)

62.6

(13) Palate, length, lingual border incisor alveoli to distal border M3

212.05

(14) Palate, length, lingual border incisor alveoli to choana

190.15

(15) Posterior skull, length (PSL/SC)

169.65

(16) Palate, width at level of C

40

(17) Palate, width at level of P1

35.9

(18) Palate, width at level of P3

31.4

(19) Palate, width at level of M1

33.1

(20) Palate, width at level of M2 (PAW)

30.4

(21) Palate, width at level of M3

32

37

(22) Occiput, height $(\mathrm{OCH})$

83.34

(23) Supraoccipital, height, nuchal crest to foramen magnum

57.8

(24) Basicranium, length (BCL) ${ }^{4}$

$135.25\left(^{*}\right)$

(25) Basicranium, width at the level of EAM

99.73

(26) Foramen magnum, height $x$ width

\section{Dentition}

(27) I1-M3, length (alveolus of I1)

$215\left(^{*}\right)$

(28) P1-M3, length

163

(29) P1-P4, length

86.7

(30) M1-M3, length

$75\left(^{*}\right)$

P1 L

$82.2(\mathrm{R}) 79.1(\mathrm{~L})$

P1 W

$18.4(\mathrm{~L})$

$11.5(\mathrm{~L})$

$21.6(\mathrm{R})$

$16.7(\mathrm{R})$

P2 W

$21.2(\mathrm{R})$

P3 L

21.1 (R)

$22.3(\mathrm{R})$

$22.6(\mathrm{R})$

P4 W

M2 L (SUML)

30.2

$31.4(\mathrm{~L}) / 30.9$ (R)

M2 W (SUMW)

M3 L

\footnotetext{
${ }^{1}$ Asterisk $\left(^{*}\right)$ indicates measurement is approximate.

2 The numbers between parentheses relate to figure 4 .

${ }^{3}$ Abbreviations in parentheses relate to body size estimators in table 4 .

${ }^{4}$ From the base of the foramen magnum to the posterior border of choana. EAM, external acoustic meatus.
} 

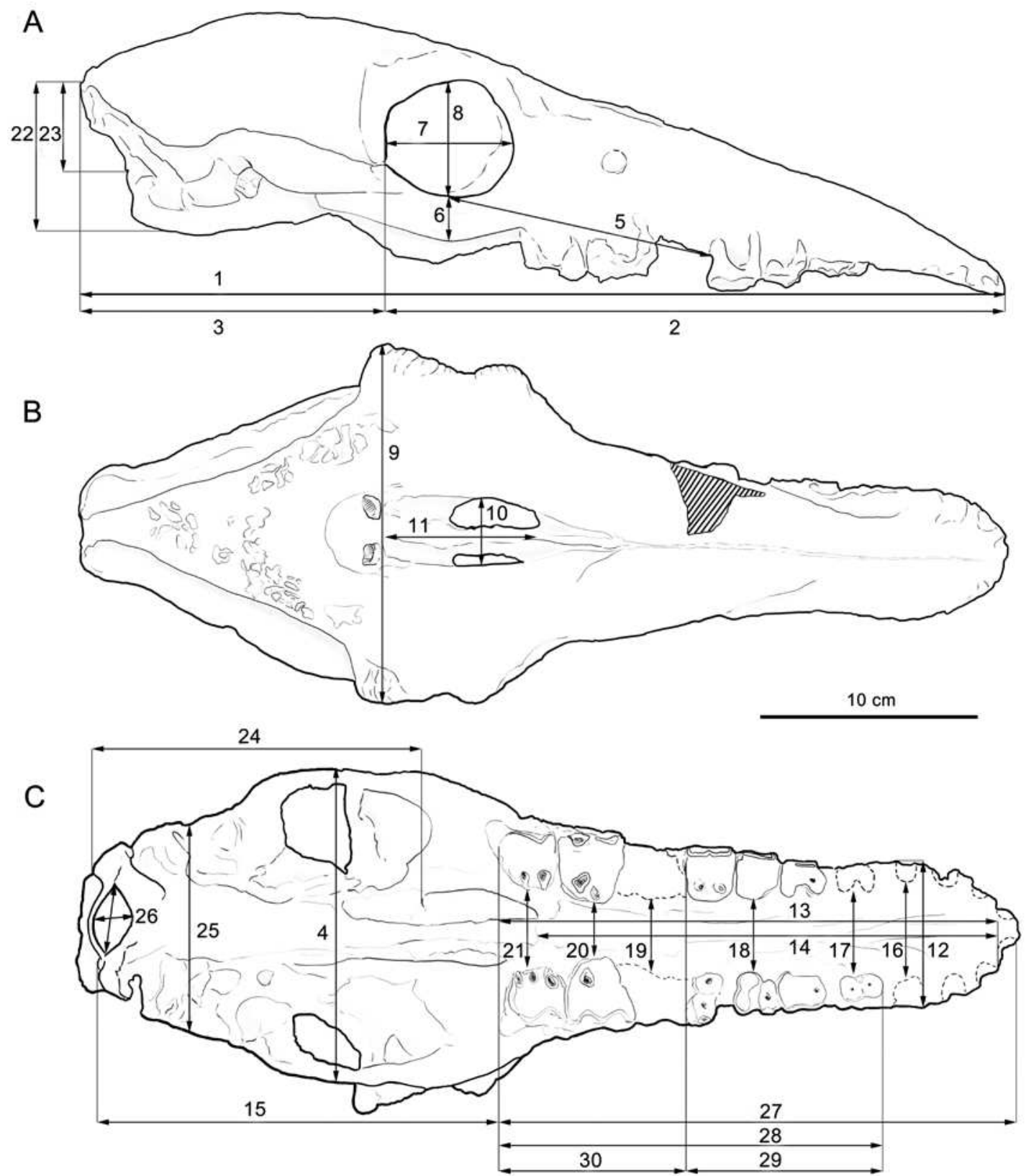

FIG. 4. Skull of Huayqueriana cf. H. cristata IANIGLA-PV 29 in A, right lateral, B, dorsal, and C, ventral views, with measurements (see table 2). 

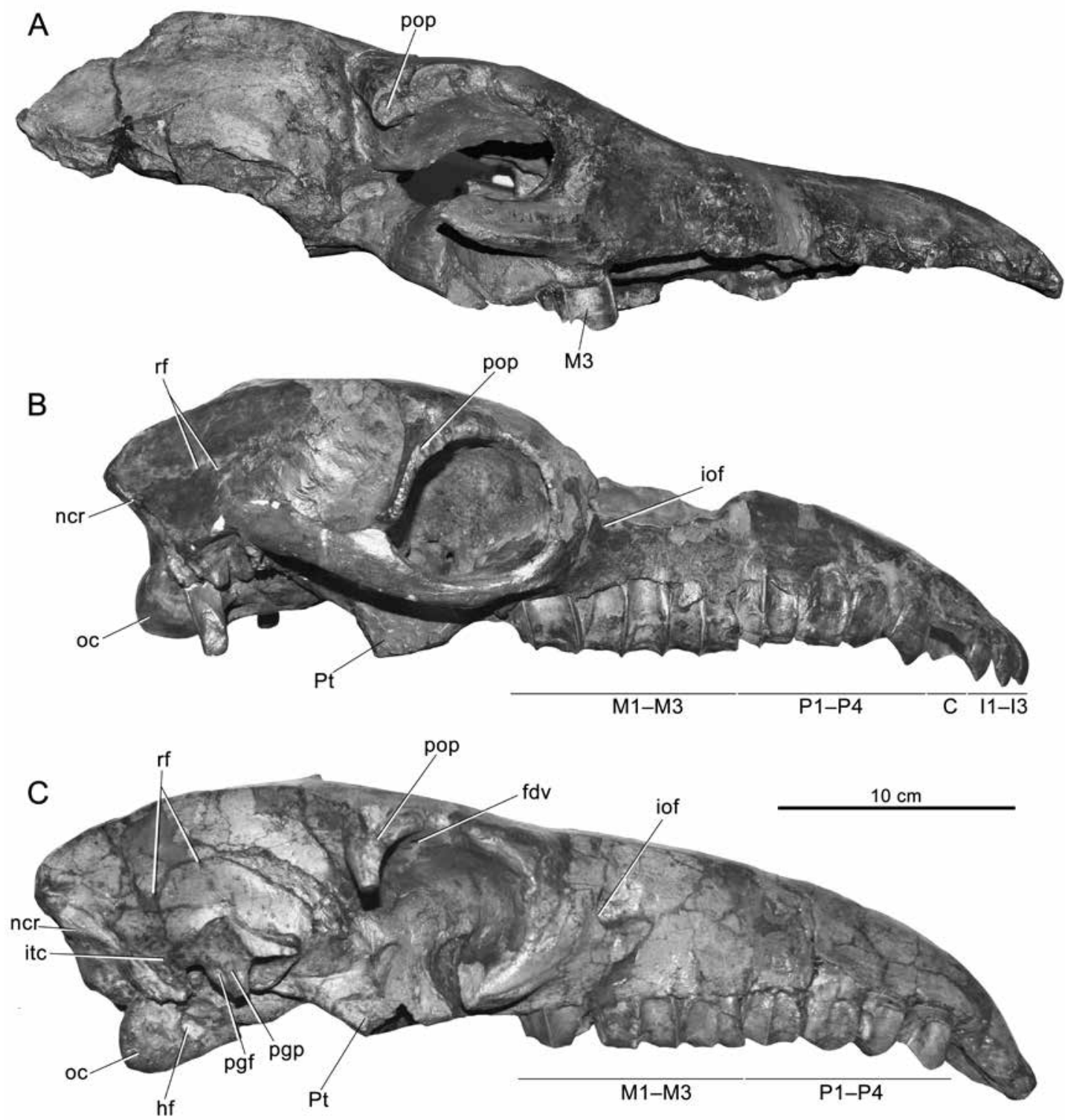

FIG. 5. Lateral views of skulls of A, Huayqueriana cristata MLP 37-III-7-2, Huayquerías Formation, Mendoza; B, Promacrauchenia antiquua MACN-PV 7986, Monte Hermoso Formation, Buenos Aires; and C, Promacrauchenia calchaquiorum MACN-PV 5528 (holotype), "estratos Araucanos," Catamarca. Abbreviations: C, canine (alveolus); fdv, foramen for frontal diploic vein; hf, hypoglossal foramen; I, incisor; iof, infraorbital foramen; itc, infratemporal crest; $\mathbf{M}$, molar; ncr, nuchal crest; oc, occipital condyle; P, premolar; pgf, postglenoid foramen; pgp, postglenoid process; pop, postorbital process of frontal; Pt, pterygoid; rf, foramina for rami temporales. 


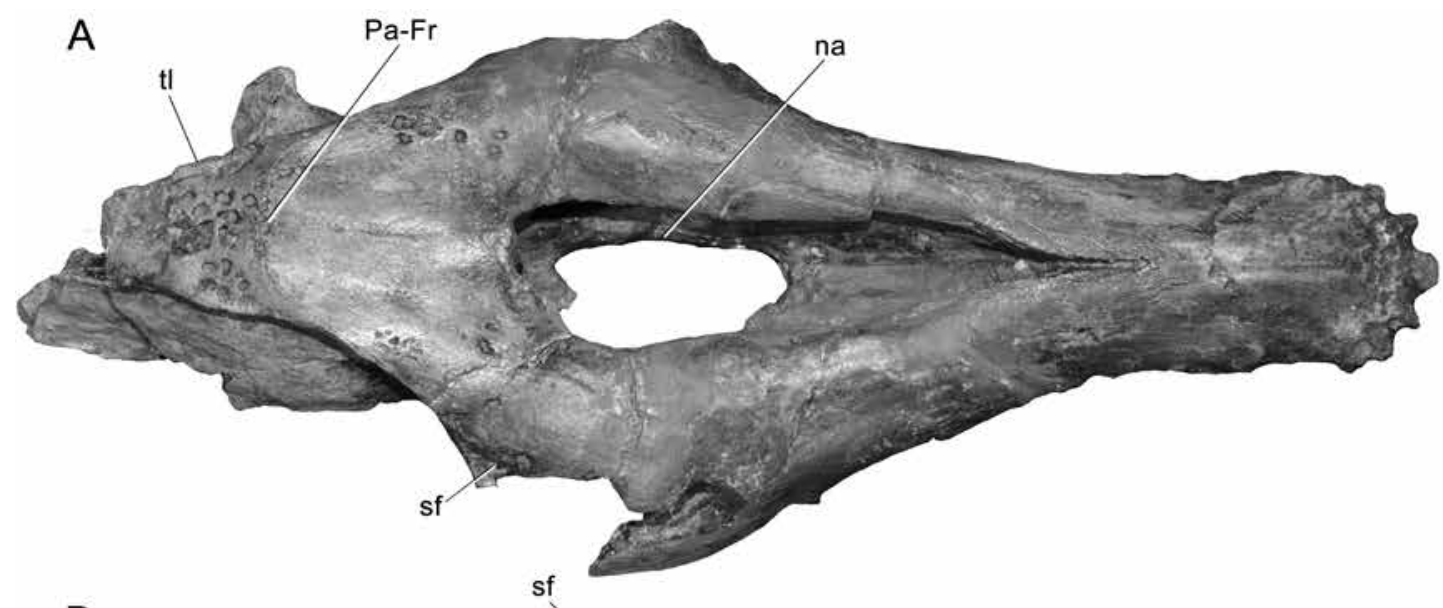

B
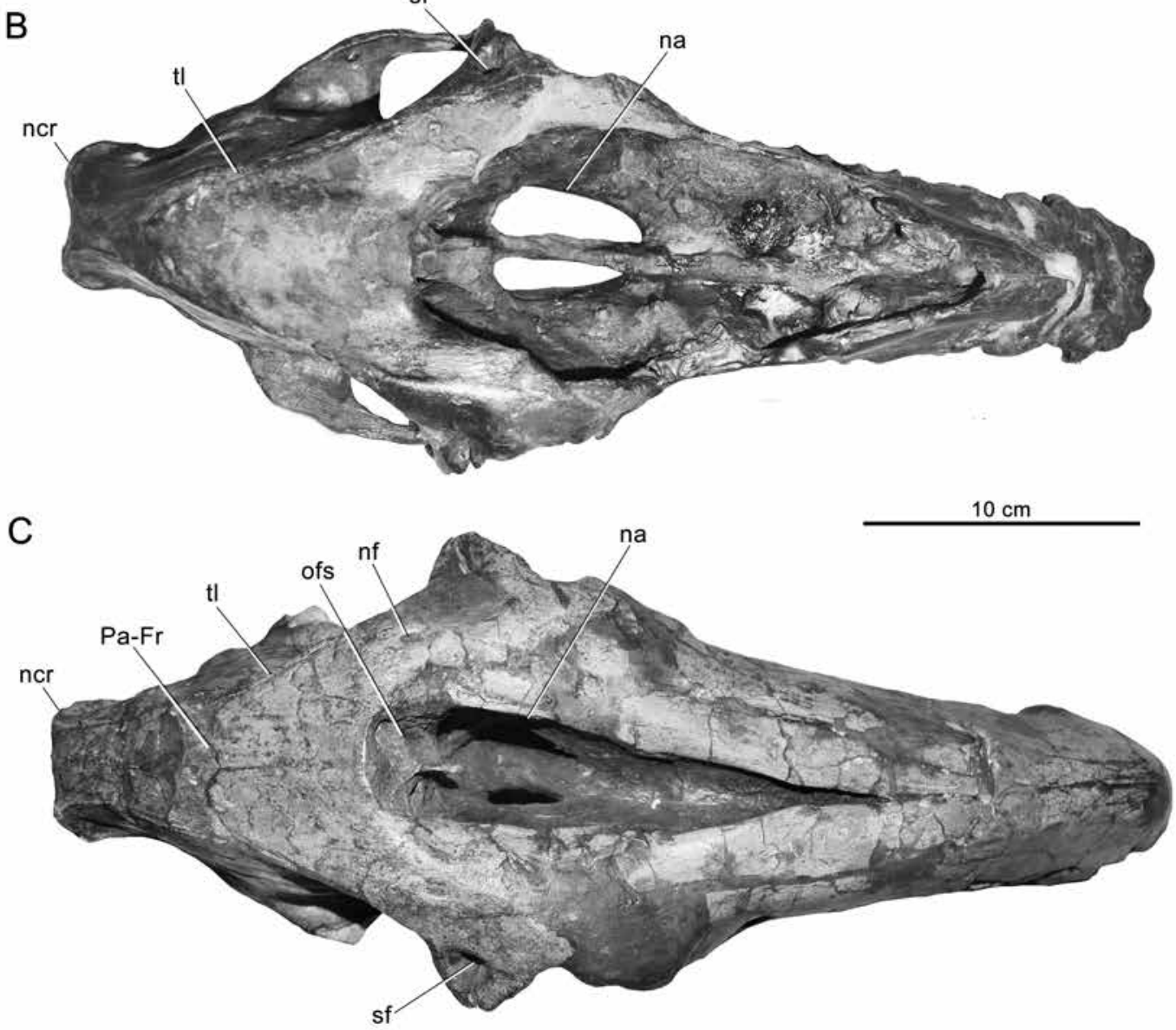

FIG. 6. Dorsal views of skulls of A, Huayqueriana cristata MLP 37-III-7-2; B, Promacrauchenia antiquua MACN-PV 7986; and C, Promacrauchenia calchaquiorum MACN-PV 5528 (holotype). For stratigraphic provenances, see figure 5. Abbreviations: Fr, frontal; na, nasal aperture; ncr, nuchal crest; nf, nutrient foramina; ofs, openings of frontal sinus; Pa, parietal; sf, supraorbital foramen; tl, temporal line. 
3B), similar to conditions in H. cristata (Soria, 1986; fig. 6A) and S. bravardi MACN-PV 8903. In contrast, in Pr. calchaquiorum (fig. 6C) the maxillae join at the transverse level of $\mathrm{M} 1$, while in M. patachonica they meet at M2 (Fernández de Álvarez, 1940).

We infer that during ontogeny the rostral border of the nasal aperture migrated progressively caudally, as in the juvenile of O. zeballosi MHIN-UNSL-GEO-V 465a (fig. 8): the maxillae meet at the DP1/DP2 level, whereas in the adult of the same species MACN-PV 13671 they do not come into contact up to the level of, or even posterior to, the mesial portion of $\mathrm{P} 3$. Its precise position in MACN-PV 13671 cannot be fixed because the maxillary nasal border is incomplete caudal to the mesial part of P3.

Compared to conditions in most other mammals, the nasal aperture of macraucheniines is remarkably derived, differing radically in its proportions and organization even from non-macraucheniine macraucheniids (Scott, 1910). Its derivative nature is especially obvious in the orientation of the passageway between the external opening of the nares and the nasopharynx. In most mammals this passageway tends to be coplanar with the palate, i.e., essentially horizontal in life position. In species with notably derived cranial modifications for head posture, such as humans, the passageway exhibits a sharp ventral bend at the level of the soft palate, such that the oropharynx joins the caudal nasal apertures at a near right angle (Hiatt and Gartner, 2001). In Huayqueriana and other macraucheniines the entire passageway is normal to the palate (figs. 3A, C; 10, 11), with the result that the large oval choanae are directed dorsoventrally, not rostrocaudally. More remarkably still, and as revealed by CT scans, the rostralmost portion of the nasal cavity still retains its primitive position, occupying the snout almost to the tip (figs. 10, $11,12 \mathrm{C}$ ). However, it is now reduced to a diverticulum, lacking any kind of entrance above the incisor row and thus having no apparent primary role as a conduit for airflow. In the tapir, a similar space occupies the rostral part of the snout (hereafter referred to as meatus nasi ventralis, cf. Witmer et al., 1999).

In ventral view, the rostral border of the right choana in IANIGLA-PV 29 is located at the transverse level of the mesial border of M3, but the left is positioned slightly more caudally, its mesial border intersecting the middle of M3. This asymmetry is probably due to taphonomic distortion. In S. bravardi MACN-PV 8903, the rostral borders of both choanae are situated even with the mesial border of M3. In Pr. antiquua and $H$. cristata MLP 41-IV-29-4 they are positioned above the mesial half of M3; in Pr. calchaquiorum, above the midsection of the tooth; and in $H$. cristata (holotype), level with the distal border of the latter. In O. zeballosi (MACN-PV 13671), the choanae lie relatively further forward, along a plane running through the middle of M2.

In ventral view, the nasal septum presents as a thick, vertical lamina separating the large choanal apertures. Most of the bony septum is evidently formed by the hypertrophied vomer (figs. $11,12 \mathrm{~F}$ ); on comparative grounds the perpendicular plate of the ethmoid must also be involved, although there is no evidence of a suture. Fernández de Álvarez (1940) established that in M. patachonica the dorsal margin of the vomer is sandwiched between the maxillae, such that its blade visibly protrudes into the external surface of the intermaxillary suture for virtually the entire length of the snout. In IANIGLA-PV 29, similar conditions are found, although the vomer's participation in the intermaxillary suture is more limited and the rostral end of the nasal septum appears to be formed exclusively by maxillary material (fig. 12D-F).

Unfortunately, delicate turbinal structures were partially destroyed during preparation of the choanae. However, enough remains of the ethmoturbinates were situated where expected, i.e., in relation to the caudodorsal end of the nasal cavity (figs. 10,11,13A), and not within the rostrally situated meatus nasi ventralis.

Although in IANIGLA-PV 29 there is no trace of sutures in the rear wall of the nasal aper- 

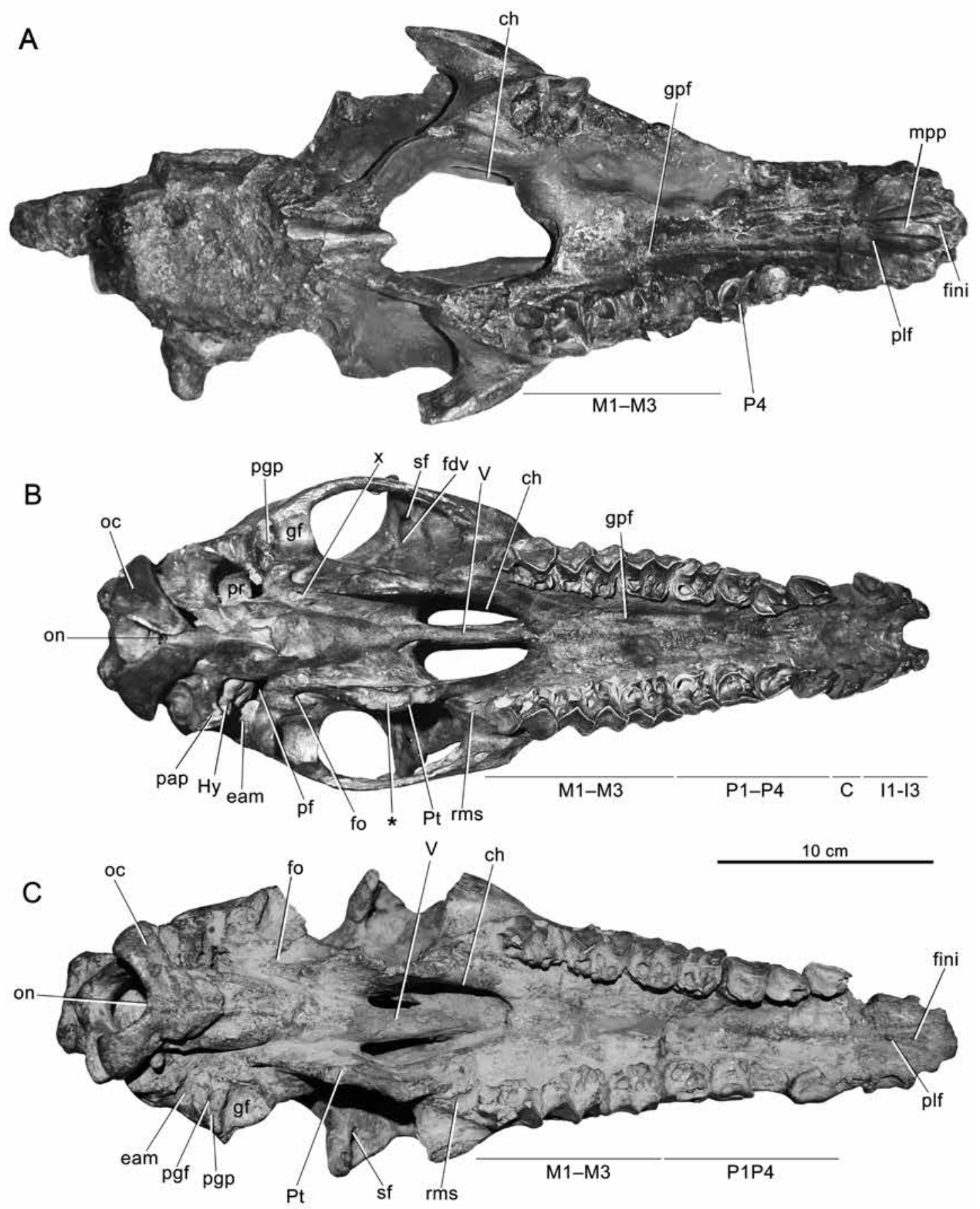
ture, the bone immediately caudal to the nasal aperture is probably composed of the two nasal bones, indivisibly fused. In the past there has been much doubt regarding this character, in part because the region in question varies considerably in appearance in different macraucheniines. Rusconi (1932) was under the impression that a similar blunt protuberance in $S$. bravardi (MACN-PV 13082; fig. 9B) was actually composed of frontal material, to which the nasals were loosely attached. Fernández de Álvarez (1940: 19) expressed a similar view in regard to M. patachonica (MACN-PV 2): "en la cresta anterior a la cavidad triangular del frontal, deben haber estado implantados los nasales. Estos faltan en el ejemplar, pero no deben haber sido muy desarrollados." However, other authors (Burmeister, 1864; Soria, 1986), as well as Fernández de Álvarez (1940) in regard to nonMacrauchenia macraucheniines, proposed that the nasals either participate in, or actually compose, the protuberance bordering on the caudal rim of the nasal aperture, in continuity with definite frontal material. More recently, Soria pointed out that in $H$. cristata (MLP 41-IV-29-4), the nasals "están reducidos y forman una ligera elevación redondeada, a modo de cresta, en el borde postero-medial de la abertura nasal" (Soria, 1986: 160).

Our reexamination of the relevant region in specimens studied by these authors, including MACN-PV 8903, MACN-PV 5528, MACN-PV 7986, MACN-PV 2, MLP 41-IV-29-4 (appendix 1 ), also failed to reveal any evidence of sutures. However, a juvenile assigned to O. zeballosi MHIN-UNSL-GEO-V 465a (Cerdeño et al.,
2008), in which several sutures and synchondroses are still partially patent, was found to exhibit the internasal suture and possibly part of the nasofrontal suture (fig. 8B). The nasofrontal suture may obliterate very early in ontogeny, as in elephants, in which it fuses sooner than the basioccipital-basisphenoid synchondrosis (e.g., Loxodonta africana) or immediately thereafter (e.g., Elephas maximus) (Rager et al., 2014).

The notion that nasals might actually be absent or detached in some specimens or species of macraucheniines may have arisen from the peculiar condition of the dorsal surface of the bony nasal septum at the point at which it meets the caudal rim of the nasal aperture. To varying degrees in different macraucheniine taxa, the last two or three centimeters of the septum broaden out into narrow wings defining a central depression. Often the surfaces of the wings are roughened, as though they supported a nonbony structure. To a degree the effect is similar to a suture, but in comparing various macraucheniines to mammals having the usual form of the nasal skeleton, we have come to the conclusion that these wings must have supported the dorsocaudal terminus of the nasal septal cartilage. On positional grounds this makes sense, but it is harder to reconstruct the form that the cartilaginous nasal septum would have taken. Witmer et al. (1999) have shown that the septal cartilage in the tapir is a decidedly complicated structure that terminates rostrally in a long fibrous cord that arcs through or under the hydrostat (proboscis) to terminate in the tissues of the upper lip. Whether mac-

FIG. 7. Ventral views of skulls of A, Huayqueriana cristata MLP 37-III-7-2; B, Promacrauchenia antiquua MACN-PV 7986; and C, Promacrauchenia calchaquiorum MACN-PV 5528 (holotype). For stratigraphic provenances, see figure 5 caption. Abbreviations: C, canine; ch, choana; eam, external acoustic meatus; fdv, foramen for frontal diplöic vein; fini, foramen interincisivum; fo, foramen ovale; gf, glenoid fossa; gpf, greater (= major) palatine foramen; Hy, hyoid (tympanohyal + stylohyal); I, incisor; $\mathbf{M}$, molar; mpp, medial palatine process of premaxilla; oc, occipital condyle; on, odontoid notch; P, premolar; pap, paracondylar process of exoccipital; pf, piriform fenestra; pgf, postglenoid foramen; pgp, postglenoid process; plf, palatine fissure; pr, promontorium; Pt, pterygoid; rms, retromolar space; sf, supraorbital foramen; $\mathbf{V}$, vomer. Letter $\mathbf{x}$, identifies canal X for nerve of pterygoid canal and vascular structures (see text). Asterisk $\left({ }^{*}\right)$ identifies marked groove on ventral margin of pterygoid plate, especially evident on MACN-PV 7986. 


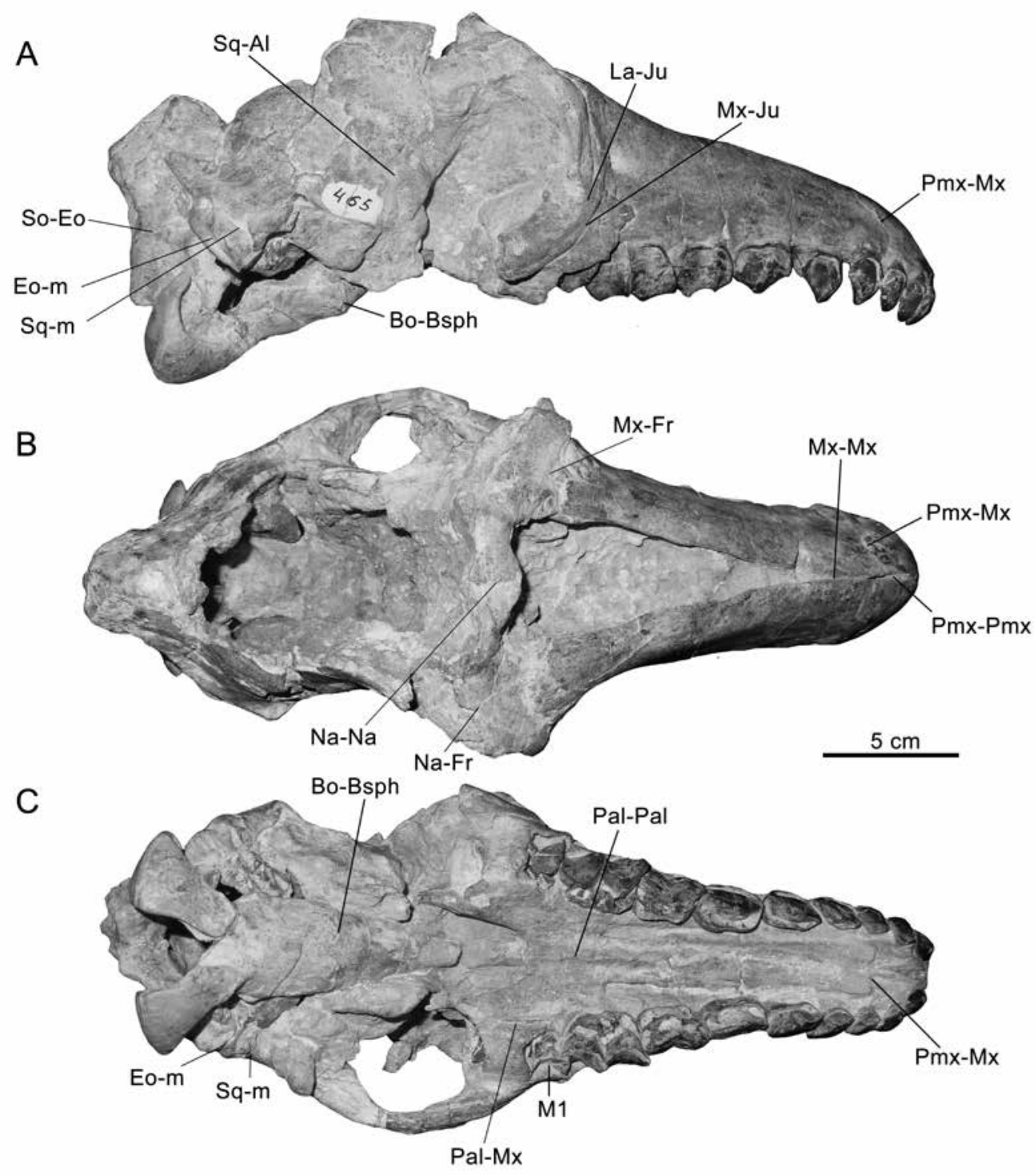

FIG. 8. Skull of Oxyodontherium zeballosi MHIN-UNSL-GEO-V 465a from Río Quinto Formation, San Luis, in A, lateral, B, dorsal, and $\mathbf{C}$, ventral views, with sutures indicated. Abbreviations: Al, alisphenoid; Bo, basioccipital; Bsph, basisphenoid; Eo, exoccipital; Fr, frontal; Ju, jugal; La, lacrimal; Mx, maxilla; Na, nasal; Pal, palatine; m, mastoid process of petrosal; Pmx, premaxilla; So, supraoccipital; Sq, squamosal. 

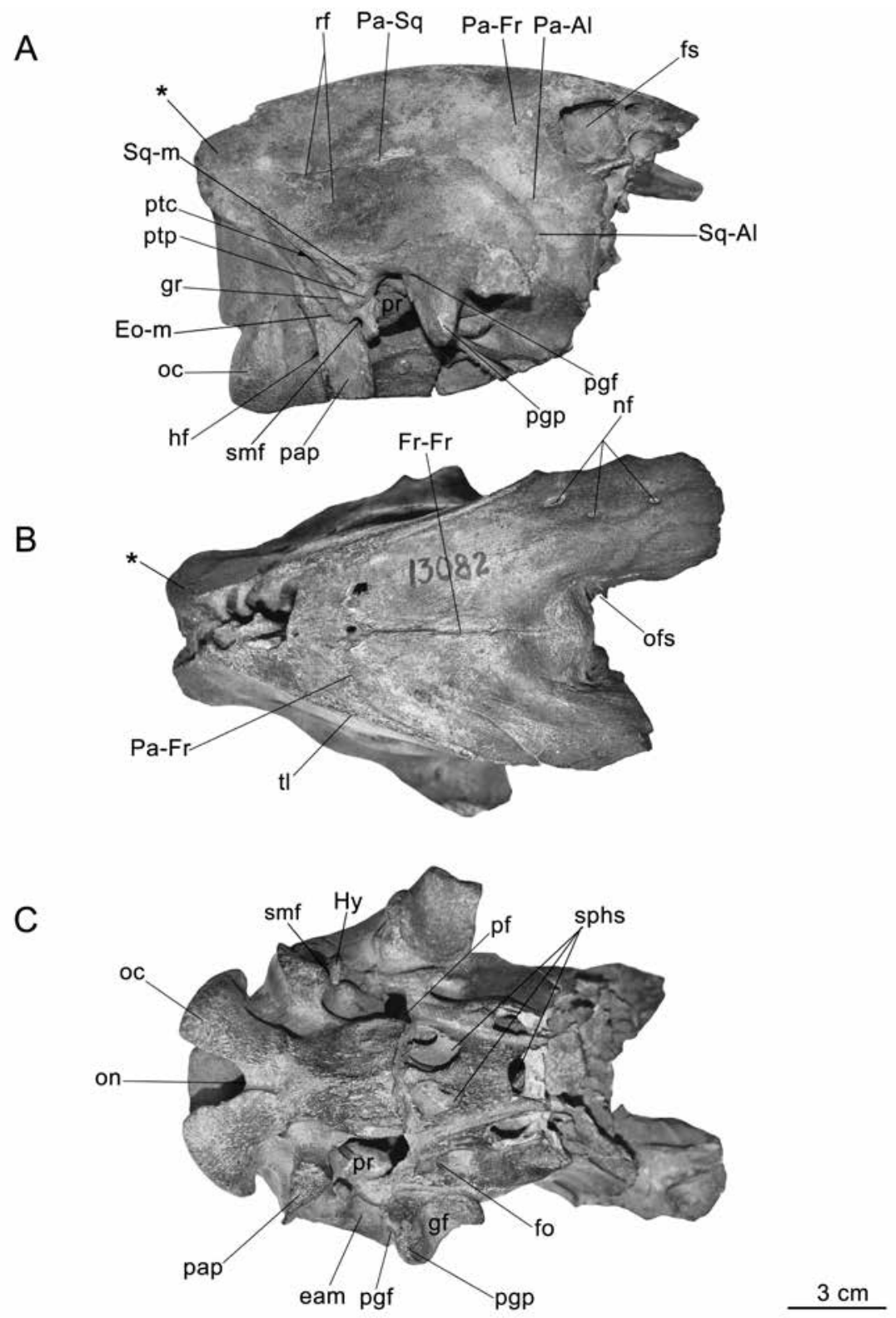

FIG. 9. Braincase of Scalabrinitherium bravardi MACN-PV 13082 from Ituzaingó Formation, Entre Ríos, in A, lateral, B, dorsal, and C, ventral views. Rostral part of specimen extensively damaged; apparent apertures on ventral aspect are not foramina but instead exposed parts of sphenoidal sinus (sphs). Other abbreviations: Al, alisphenoid; eam, external acoustic meatus; Eo, exoccipital; fo, foramen ovale; Fr, frontal; fs, frontal sinus; gf, glenoid fossa; gr, occipital groove; hf, hypoglossal foramen; Hy, hyoid (tympanohyal + stylohyal); m, mastoid process of petrosal; nf, nutrient foramina; oc, occipital condyle; ofs, openings of frontal sinus; on, odontoid notch; Pa, parietal; pap, paracondylar process of exoccipital; pf, piriform fenestra; pgf, postglenoid foramen; pgp, postglenoid process; pr, promontorium; ptc, posttemporal canal; ptp, posttympanic process of squamosal; rf, foramina for rami temporales; smf, stylomastoid foramen; Sq, squamosal; tl, temporal line. Asterisk $\left(^{*}\right)$ identifies suture-delimited element, probably interparietal. 

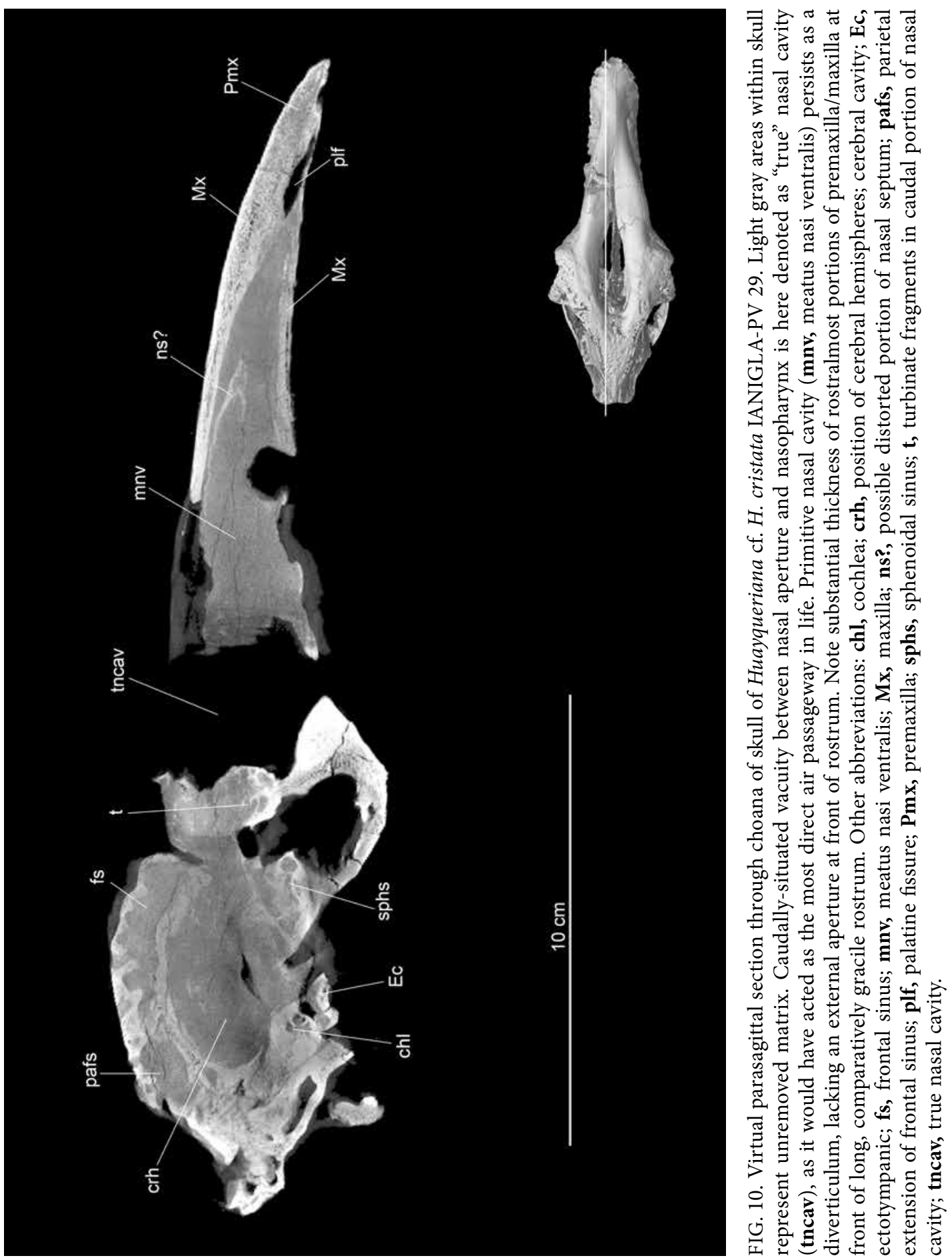

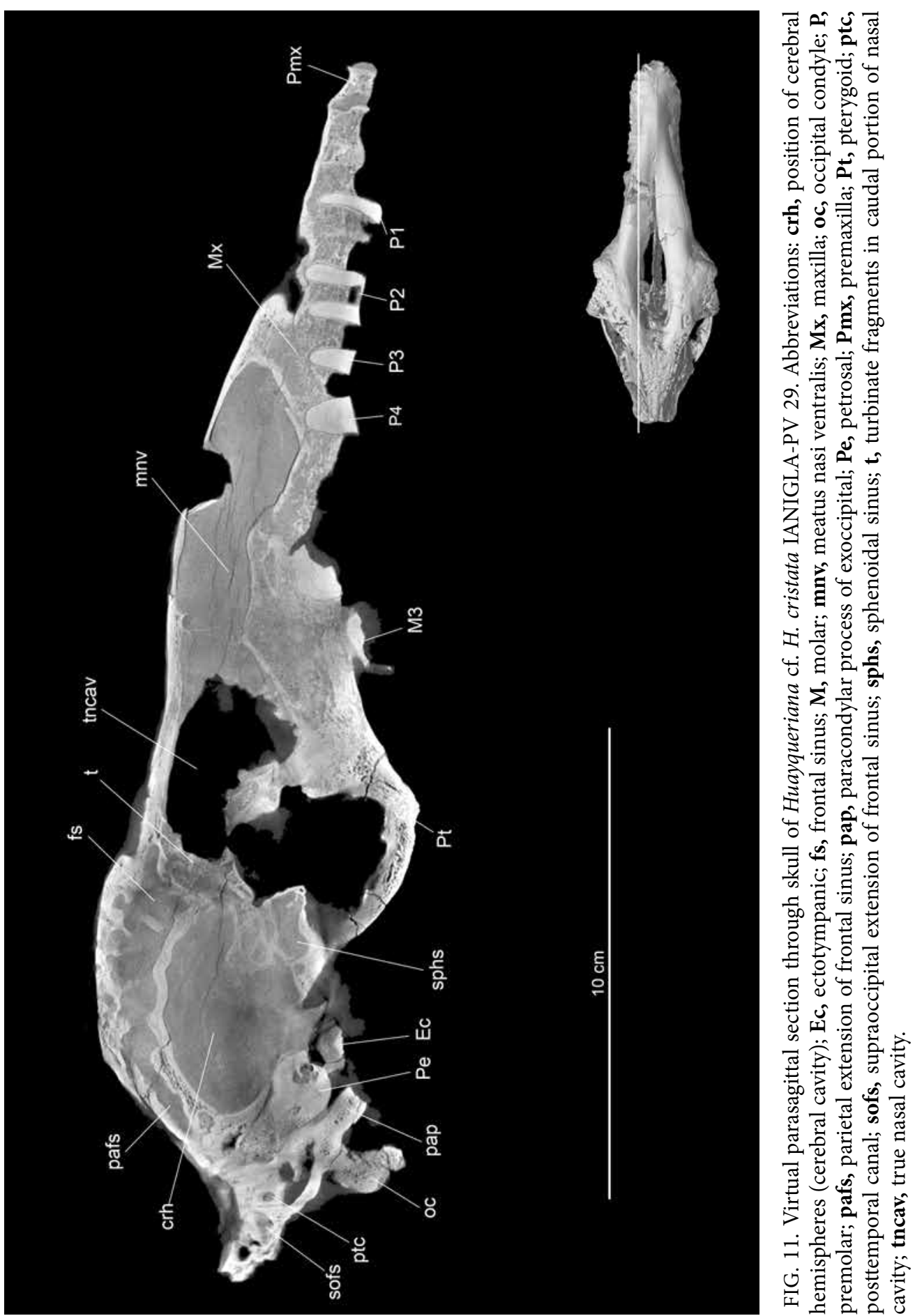


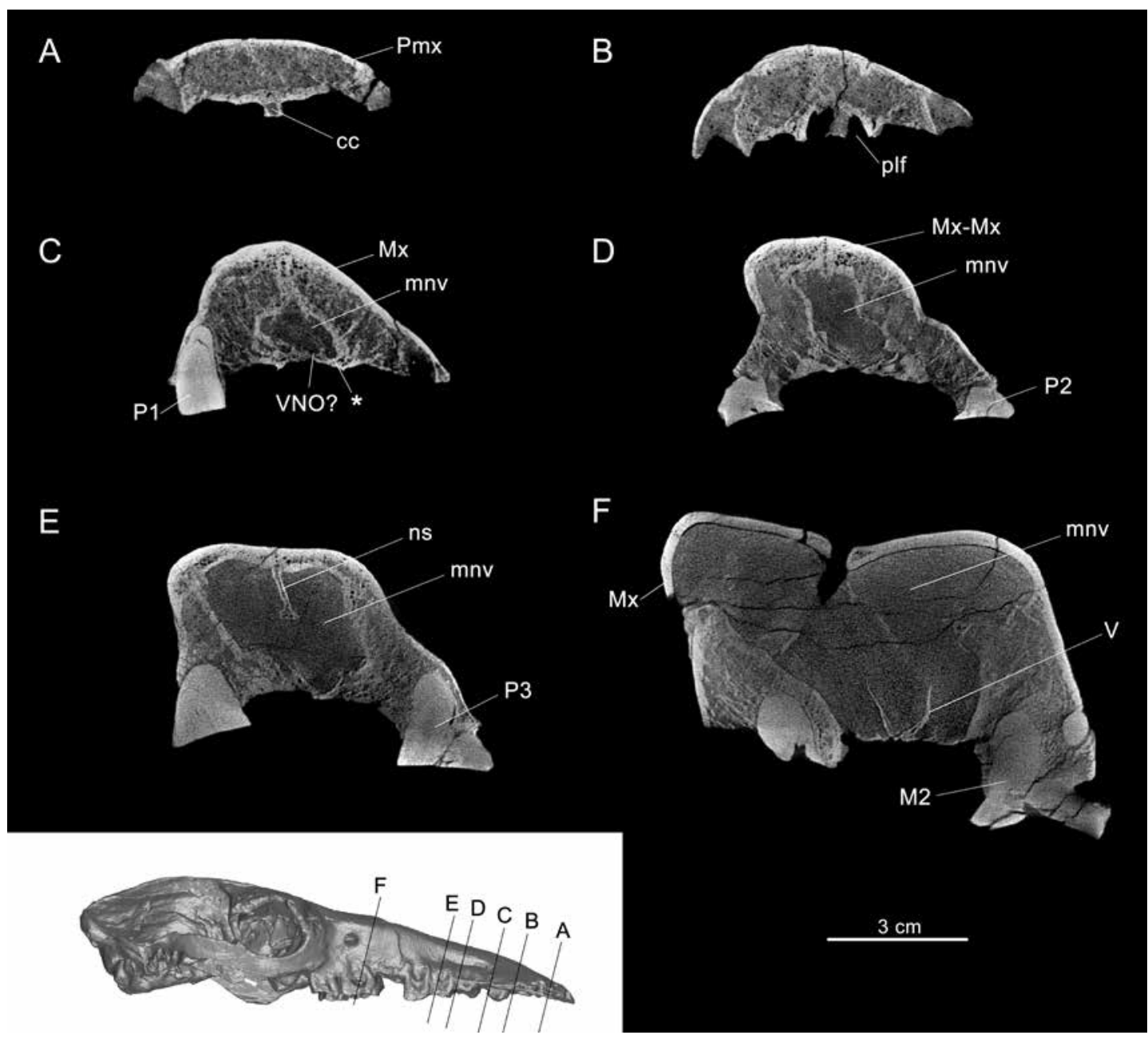

FIG. 12. A-F, Virtual coronal sections of skull of Huayqueriana cf. H. cristata IANIGLA-PV 29. Abbreviations: cc, central canal; $\mathbf{M}$, molar; mnv, meatus nasi ventralis; $\mathbf{M x}$, maxilla; ns, nasal septum; P, premolar; plf, palatine fissure; Pmx, premaxilla; V, vomer; VNO?, possible sulcus for vomeronasal organ. Asterisk $\left(^{*}\right)$ identifies sulcus for vascular structures (see text).

raucheniines possessed anything similar is of course unknown, although the unusual degree of vomer exposure in the intermaxillary suture may imply actual prolongation of the nasal cartilage onto (or into) the face.

In summary, the preponderance of evidence indicates that the nasals were very small in macraucheniines and projected little or not at all beyond the caudal rim of the nasal aperture, a decided similarity to elephants, less so to other taxa possessing prominent nasal ornamentations such as Tapirus and Saiga.

\section{Palate}

In ventral view (fig. 3C), the hard palate of IANIGLA-PV 29 is narrow and uniform in width (table 2; fig. 4C). Allowing for size, the palate appears narrower than in other macraucheniines (fig. 7), although this could be a consequence of taphonomic compression.

The rostralmost part of the palate exhibits a midline aperture and an associated canal, as well as two laterally positioned, sharply bordered dehiscences, the palatine fissures (= palatal 


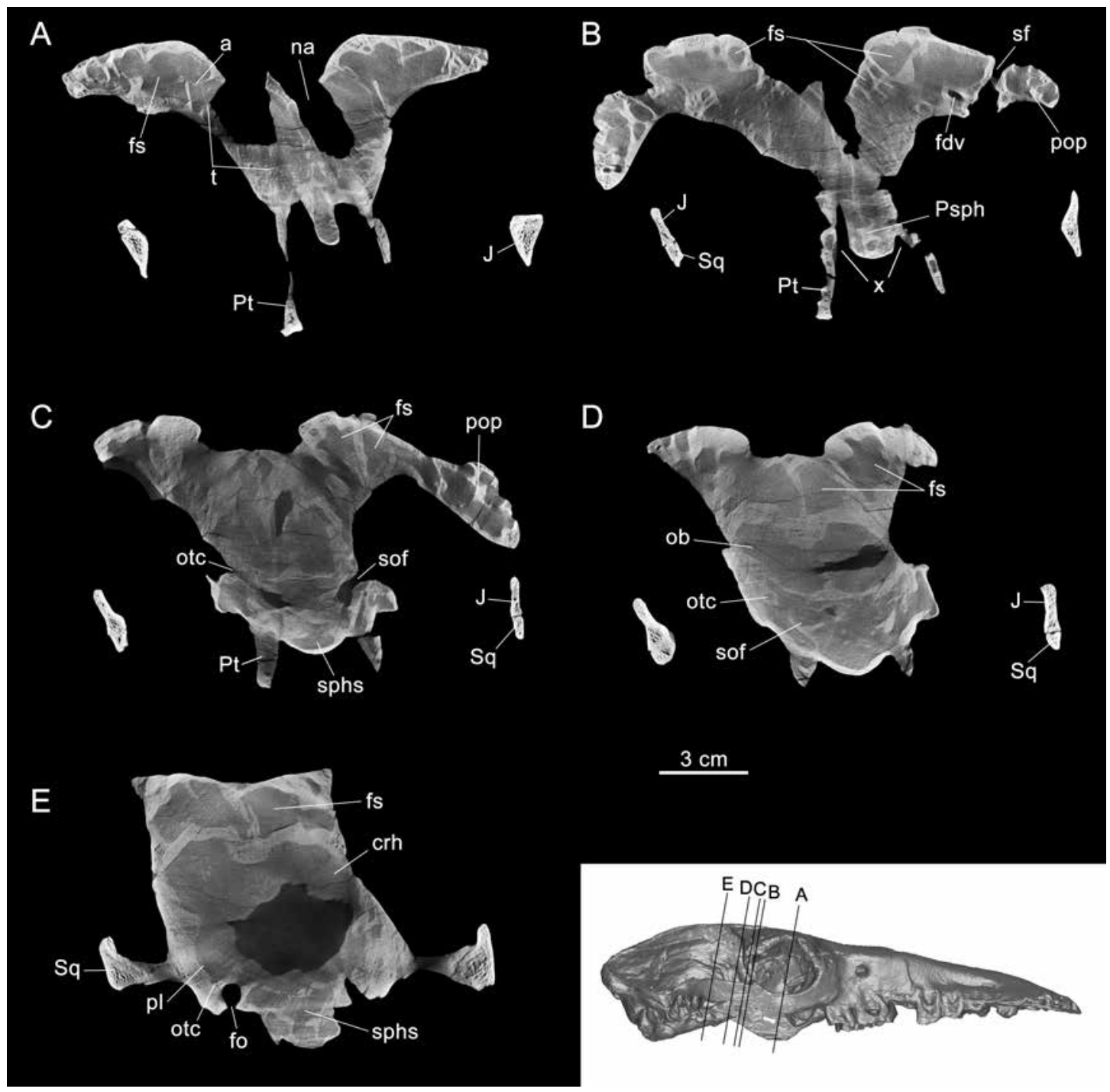

FIG. 13. A-E, Virtual coronal sections of skull of Huayqueriana cf. H. cristata IANIGLA-PV 29. Abbreviations: a, aditus to frontal sinus; crh, position of cerebral hemispheres; fdv, foramen for frontal diploëic vein; fo, foramen ovale; fs, frontal sinus; J, jugal; na, nasal aperture; ob, position of olfactory bulb; otc, orbitotemporal canal; pl, position of piriform lobe; pop, postorbital process of frontal; Psph, presphenoid; Pt, pterygoid; sf, supraorbital foramen with perforating canal; sof, sphenoorbital fissure; Sq, squamosal (zygomatic process); sphs, sphenoidal sinus; $\mathbf{t}$, turbinals. Letter $\mathbf{x}$, identifies canal $\mathrm{X}$ for nerve of pterygoid canal and vascular structures (see text).

fenestrae) (fig. 3C). The midline aperture, which we consider the operational homolog of the perissodactyl foramen interincisivum (= foramen palatinum medium; Maier, 2002), is located at the rostral end of a long $(3 \mathrm{~cm})$, somewhat elevated tube (hereafter, the central canal; fig. 12A). This foramen is also present in Huayqueri- ana cristata MLP 41-IV-29-4. Unlike the primitive incisive foramina of mammalian anatomy, foramen interincisivum is unpaired.

The raised ridge housing the central canal probably exists in other macraucheniines (e.g., O. zeballosi MHIN-UNSL-GEO-V 465a; M. patachonica MACN-PV 2), but its identity as a conduit is obvi- 
ous only when scans are examined. The foramen interincisivum is broad and V-shaped in ventral view, and is situated just posterior to the alveoli of the mesial incisors, as in other macraucheniines (e.g., S. bravardi MACN-A 1270, Pr. calchaquiorum, and O. zeballosi MHIN-UNSL-GEO-V 465a; figs. $7,8 \mathrm{C}$ ). This opening rapidly narrows into the central canal proper, which is only a few millimeters wide (fig. 12A). The canal becomes continuous with the meatus nasi ventralis at the approximate level of the rostral border of P1.

Two deep palatal grooves are developed lateral and caudal to the central canal (fig. 3C), as in other macraucheniines (figs. 7, 8). These grooves open into the palatine fissures at the level of the canine alveoli (figs. 10, 12B; contra Scott 1910: 117, who thought only grooves were present). These fissures are caudally continuous with grooves on the floor of the meatus nasi ventralis, possibly for divisions of the greater (= major) palatine artery and nerve. Thus, the fissures presumably reflect the passage of those soft tissue structures from the meatus nasi ventralis, into the rostral part of the upper jaw.

There are at least two possibilities for the contents of the central canal, based on conditions in modern perissodactyls (Equus). The first concerns the arteria incisiva (= palatolabial artery), a terminal division of the greater palatine artery (Sisson and Grossman, 1975; Vogt, 2011). The arteria incisiva is formed by the union of two branches of the greater palatine artery to form a single median vessel, which enters the foramen interincisivum immediately behind the medial incisors (Sisson and Grossman, 1975). The vessel thereafter ascends dorsocaudally to emerge from its exit foramen situated on the nasal sill. In Equus, the arteria incisiva is transmitted via the foramen interincisivum to the upper lip, where it releases dorsal and ventral septal branches destined for the nasal cavity and the transversus nasi muscle and upper lip. By contrast, Huayqueriana, like Tapirus, lacks a large foramen opening dorsally on the forward margin of the rostrum. Thus, if the central canal contained the homolog of the arteria incisiva of the horse, it differed from the latter in its area of supply.
The second possibility for the content of the central canal is related to innervation. Although in mammals the upper lip is mainly supplied with sensory fibers by the infraorbital nerve, applied anaesthesia on the horse (Vogt, 2011) indicates that the nasopalatine nerve also passes through the foramen interincisivum. In most mammals, the nasopalatine nerve, a long branch of the posterior superior nasal branches of $\mathrm{CN}$ $\mathrm{V}_{2}$, runs between the nasal septum and the mucus membrane to reach ports within the incisive canal, through which it passes to communicate with the greater palatine nerve (Hiatt and Gartner, 2001). In shrews (e.g., Neomys) the nasopalatine nerve crosses the hard palate via a single midline opening in the rostral part of the snout (Maier, 2002), which strongly recalls the condition in Huayqueriana.

We consider it highly unlikely that the nasopalatine (= incisive) ducts, the structures that connect the vomeronasal organ (VNO) (= Jacobson's organ) to the external environment, passed through the foramen interincisivum/central canal complex rather than the palatal fissures. Although probably present in life, the VNO's position in the fossil is uncertain. As may be seen in figure $12 \mathrm{C}$, small paired depressions in the rostralmost part of the meatus nasi ventralis are consistent with VNO presence, but whether they are actually related to this organ or simply mark the passage of blood vessels, alveolar nerves, or attachment points of the septal cartilage cannot be settled. In any case, as seen in the horse and tapir (von Mering, 1994; Witmer et al., 1999), for example, the nasopalatine ducts are paired and follow separate, oblique pathways to the ipsilateral VNO. The midsagittal position of the central canal is inconsistent with such a routing. It is much more likely that the ducts passed through the wide palatine fissures, as in modern perissodactyls (e.g., von Mering, 1994; Witmer et al., 1999).

Caudal to the foregoing, the hard palate is incised by two major grooves that run in parallel from the greater palatine foramina. The greater palatine foramina are small and asymmetrically 
located: the one on the right is at the level of the M2/M3 embrasure, while that on the left is in line with the middle of M3 (fig. 3C). There is variation in the position of the palatine foramina in our comparative set. In O. zeballosi MACNPV 13671, the right aperture is situated at the level of the distal portion of M1; in Pr. antiquua (fig. 7B) the foramina intersect a line drawn through the midpart of M1 (similar to H. cristata MLP 41-IV-29-4 and M. patachonica MACN-PV 2; Fernández de Álvarez, 1940). In S. bravardi MACN-PV 8903 the palatine foramina open at the level of the mesial half of M2, while in $P r$. calchaquiorum (fig. 7C) and X. bahiense they open in line with the middle of M2 (Cartelle and Lessa, 1988: 6). In the holotype of $H$. cristata (fig. $2 \mathrm{~B})$, the right greater palatine foramen opens at the level of the middle of M2 while the left does so at the level of the mesial portion of M3.

The retromolar space on the maxilla of IANIGLA-PV 29 is almost as long as the M3 itself (fig. $3 \mathrm{C}$ ), as in other examined macraucheniines (fig. 7), except for O. zeballosi MACN-PV 13671 and MACN-PV 17745 in which this space is somewhat shorter.

The pterygoids of IANIGLA-PV 29 are roughly triangular and platelike in shape. Even though we are aware that the pterygoid hamulus is a delicate structure often broken in skulls, our observations on several macraucheniine specimens strongly indicate that there is no hamulus in Huayqueriana (fig. 3C), a fact that Scott (1910) previously noted for Theosodon. However, in Huayqueriana the ventral margin of the pterygoid plate is of unusual construction. Here, a curved longitudinal groove indents the margin along its entire length. A similar feature is seen in Pr. antiquua (fig. 7B) and Promacrauchenia sp. MLP 29-X-10-16, in which the groove is deep enough to partially divide the pterygoid plate into inner and outer moities. Its smooth floor and distinctive form are consistent with its occupation in life by a muscle belly or tendon (?tensor veli palatini), suggesting that this feature may have acted as a pulley to tense soft tissue structures related to the choanal opening.

\section{Orbit}

Because of the extraordinary length of the rostrum, the orbits seem to be situated relatively caudally, as in other macraucheniids. Positional relationships of the molar teeth to the orbit vary in our comparative set. In IANIGLA-PV 29 (fig. 3A) and in the holotype of $H$. cristata (fig. 2A), the rostral border of the orbit is almost level with the distal border of M3, similar to Pr. calchaquiorum (fig. 5C). In Pr. antiquua (fig. 5B), S. bravardi MACNPV 8903, and H. cristata MLP 41-IV-29-4 (fig. 4A), the border is level with the middle of M3, while in O. zeballosi it intersects a plane drawn through the mesial portion of M3. In M. patachonica, the orbital margin lies behind the transverse position of the last molar (Fernández de Álvarez, 1940).

The orbital borders are prominent (fig. 3B) and feature a massive, ventrally projecting postorbital process (fig. 3A). The process does not form a complete, Equus-like postorbital bar because there is a small gap between the zygomatic process of the frontal and that of the squamosal, similar to the condition found in Pr. antiquua and Pr. calchaquiorum. In Theosodon (Scott, 1910) and Cramauchenia (Dozo and Vera, 2010), the gap is relatively larger. By contrast, in $X$. bahiense and M. patachonica the bar is continuous and thus the orbit is completely encircled by bone (Scott, 1910; Soria, 1986; Cartelle and Lessa, 1988). According to Rovereto (1914, plate XXIX.4), the postorbital bar was reportedly complete in the holotype of $H$. cristata. This part of the skull is unfortunately now missing (fig. 2) and the specimen is in any case clearly dorsoventrally compressed. Considering how narrow the gap is in IANIGLA-PV 29 and Pr. antiquua, the apparent absence of a gap in the holotype of $H$. cristata may likewise be an artifact of taphonomic deformation. As the actual situation is ambiguous, we prefer to consider complete closure as uncertain in the holotype. There is a postorbital constriction in IANIGLA-PV 29 as in other macraucheniines, although this is not apparent in dorsal view because of the lateral projection of the temporal lines. 

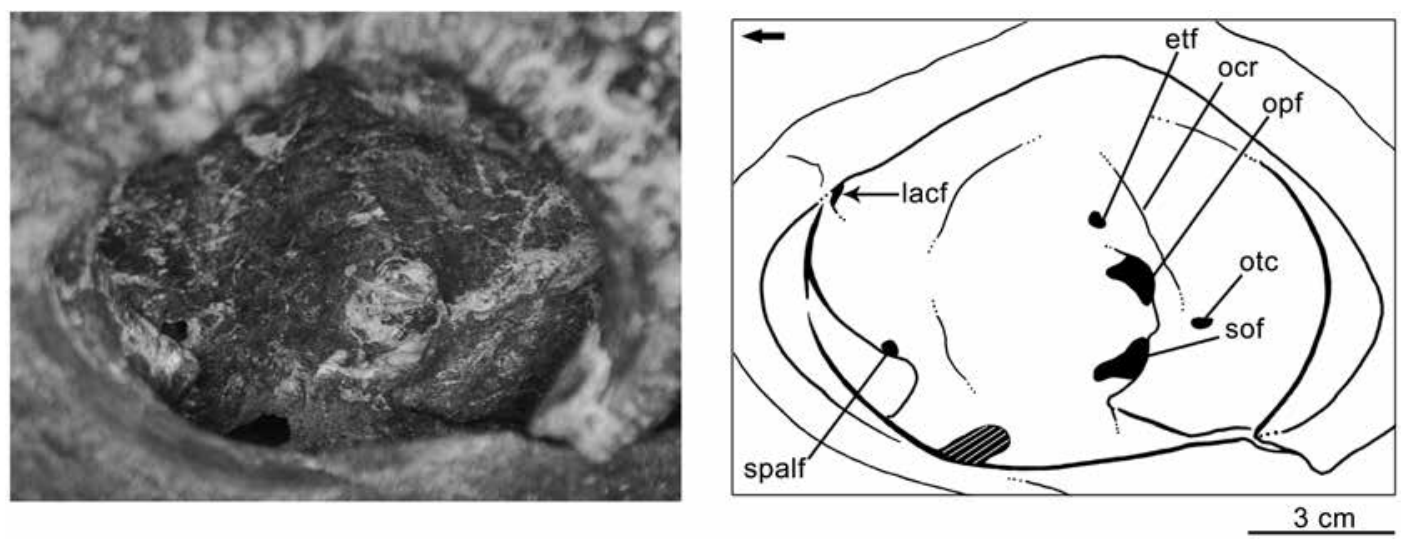

FIG. 14. Detail of orbit of Huayqueriana cf. H. cristata IANIGLA-PV 29. Abbreviations: etf, ethmoidal foramen; lacf, lacrimal foramen; ocr, orbital crest; opf, optic foramen; otc, orbitotemporal canal; sof, sphenoorbital fissure; spalf, sphenopalatine foramen. Arrow points rostrally.

There is a small, single lacrimal foramen opening inside the orbit (fig. 14), as in Pr. calchaquiorum and M. patachonica. Each orbital roof is pierced by two foramina (figs. 3B, 13B). As seen from within the orbit, the lateral aperture opens on the summit of the postorbital process of the frontal (fig. 13B). We interpret this channel as the supraorbital foramen for the supraorbital artery and its accompanying vein. In adult mammals the artery is usually a branch of the deep temporal or maxillary artery, supplying the muscles and skin above the orbit, as in the horse (Sisson and Grossman, 1975). The medial aperture passes into the substance of the bone of the medial wall of the orbit (fig. 13B). We infer that this passageway carried a vein only, as seen in certain extant mammals (Wible and Gaudin, 2004; Wible, 2008), in this case draining the frontal diploë to the supraorbital vein. Similar foramina can be found on the orbital roof of other macraucheniines (Pr. antiquua, Pr. calchaquiorum, and M. patachonica) (figs. 5-7).

The orbitotemporal fossa of IANIGLA-PV 29 (fig. 14) is very similar to that of some notoungulates (e.g., Toxodontia; Gabbert, 2004; Forasiepi et al., 2015b). There are three main apertures, dorsally bordered by the orbital crest. The two larger openings - the sphenoorbital fissure and the optic foramen-lie close to each other on the floor of the fossa. The remaining aperture-the ethmoidal foramen-is much smaller and lies rostrodorsally.

The sphenopalatine foramen opens on the floor of the orbitotemporal fossa (fig. 14), level with and rostral to the sphenoorbital fissure. This opening is large, oval, and communicates with the nasal cavity. On the left side of the skull, there is an opening at the base of the orbital crest, which suggests the presence of a small vessel communicating with the orbital cavity, here interpreted as the orbitotemporal canal (figs. 13C, 14; see Cerebral Endocast). A similar small opening in the orbital crest, at the transverse level of the optic foramen, was bilaterally present in M. patachonica (MACN-PV 2).

\section{VAULT}

The skull roof is roughly triangular in dorsal view, ornamented by a network of irregular pits and scars of uncertain significance (fig. 3B). This roughened surface continues onto the postorbital process and supraorbital area. There is a small nutrient foramen on each side of the skull at the level of the caudal border of the nasal aperture. Similar openings were observed on the vault of Pr. antiquua, Pr. calchaquiorum, M. patachonica MACN-PV 2, and S. bravardi MACN-PV 13082 and MACN-PV 8903. The frontal is flat in $P r$. antiquua (fig. 6B), Pr. calchaquiorum (fig. 6C), 
and S. bravardi (fig. 9B); M. patachonica and W. delacroixi differ in that their frontals exhibit a number of large, shallow fossae grouped immediately caudal to the nasal aperture (Burmeister, 1864; Rusconi, 1932; Fernández de Álvarez, 1940). In M. patachonica MACN-PV 2 these fossae, partially subdivided by low septa, occupy a reniform space that is more than $7 \mathrm{~cm}$ wide and at least $3 \mathrm{~cm}$ deep. Interestingly, Tapirus displays differently positioned fossae for the so-called nasofrontal sacs originally described by Murie (1872) (= diverticulum meatus of Witmer et al., 1999). In the case of the tapir, the fossae contain glandular tissues that are connected by a channel to the nasal cavity (Witmer et al., 1999).

The broadly curving temporal lines on the rear part of the vault are very distinct and converge in the direction of the nuchal crest, which they join separately (fig. 3B). Despite their proximity caudally, the temporal lines do not actually meet in the midline and consequently there is no sagittal crest in IANIGLA-PV 29. There is instead a flat polygonal area, seen also in MLP 41-IV-294, a specimen referred to $H$. cristata (fig. 6A), $P r$. antiquua (fig. 6B), Pr. calchaquiorum (fig. 6C), S. bravardi (fig. 9B), M. patachonica, and, apparently, in X. bahiense (Burmeister, 1864; Rusconi, 1932; Fernández de Álvarez, 1940; Soria, 1986; Cartelle and Lessa, 1988). The holotype of $H$. cristata (fig. 2C), by contrast, possesses a short, caudally situated sagittal crest, resembling nonmacraucheniine litopterns in this regard (Scott, 1910; Soria, 1986; Dozo and Vera, 2010). This difference may correspond to intraspecific variation (see Discussion). The nuchal crests of IANIGLA-PV 29 are also substantial, and connect with a sharply defined infratemporal crests about the level of the external acoustic meatus, directed toward the zygoma on each side of the skull.

The attachment area for the temporalis muscle is likewise bordered by three prominent crests: the temporal line dorsally, nuchal crest caudally, and the infratemporal crest ventrally. There are several foramina in the caudal part of the temporal fossa, some of which are associated with grooves marking the passage of vessels. Similar openings are present in several other litopterns and have been given names such as foramen postsquamosale or foramen postparietale by different authors (e.g., in Thoatherium minusculum, Tetramerorhinus lucarius, Cramauchenia normalis, species of Theosodon, H. cristata, Promacrauchenia spp., S. bravardi, M. patachonica; Rusconi, 1932; Scott, 1910; Dozo and Vera, 2010; Fernández de Álvarez, 1940; figs. 2C, 6, 8A). We interpret these openings as conforming to foramina for rami temporales, seen in many other mammals (see Cerebral Endocast) and recently described for certain notoungulates (MacPhee, 2014; Forasiepi et al., 2015b; see also squamosal-parietal fenestration in GarcíaLópez and Powell, 2011: fig. 1C).

\section{Zygomatic Arch}

The short and slender zygomatic arch is formed by the jugal and squamosal, which define between them an obliquely oriented suture (fig. $3 \mathrm{~A})$. The maxilla does not contribute to the ventral orbital rim in lateral view. The suture between the maxilla and jugal is almost vertical and above the M3 (this suture is oblique in the juvenile specimen of $O$. zeballosi MHIN-UNSLGEO-V 465a; fig. 8A).

The zygomatic process of the squamosal is lengthy and extends onto the caudoventral margin of the orbit, as in other macraucheniids (e.g., Cr. normalis, Pr. antiquua, M. patachonica). The squamosal has a small, triangular frontal (= dorsal) process that contributes to the osseous caudal border of the orbit and thereby provides attachment for the postorbital ligament separating the orbital and temporal fossae (Wible, 2003). In other mammals this process is normally formed by the jugal (Wible, 2003; Sisson and Grossman, 1975), which, in conjunction with the postorbital process of the frontal, form the caudal border of the orbit.

\section{BASICRANIUM}

The basicranium in IANIGLA-PV 29 is long and narrow (fig. 15), as in other macraucheniids (fig. 7), with a convex ventral surface. Scott (1910) described a longitudinal crest on the basioccipital of Theosodon and observed that it 

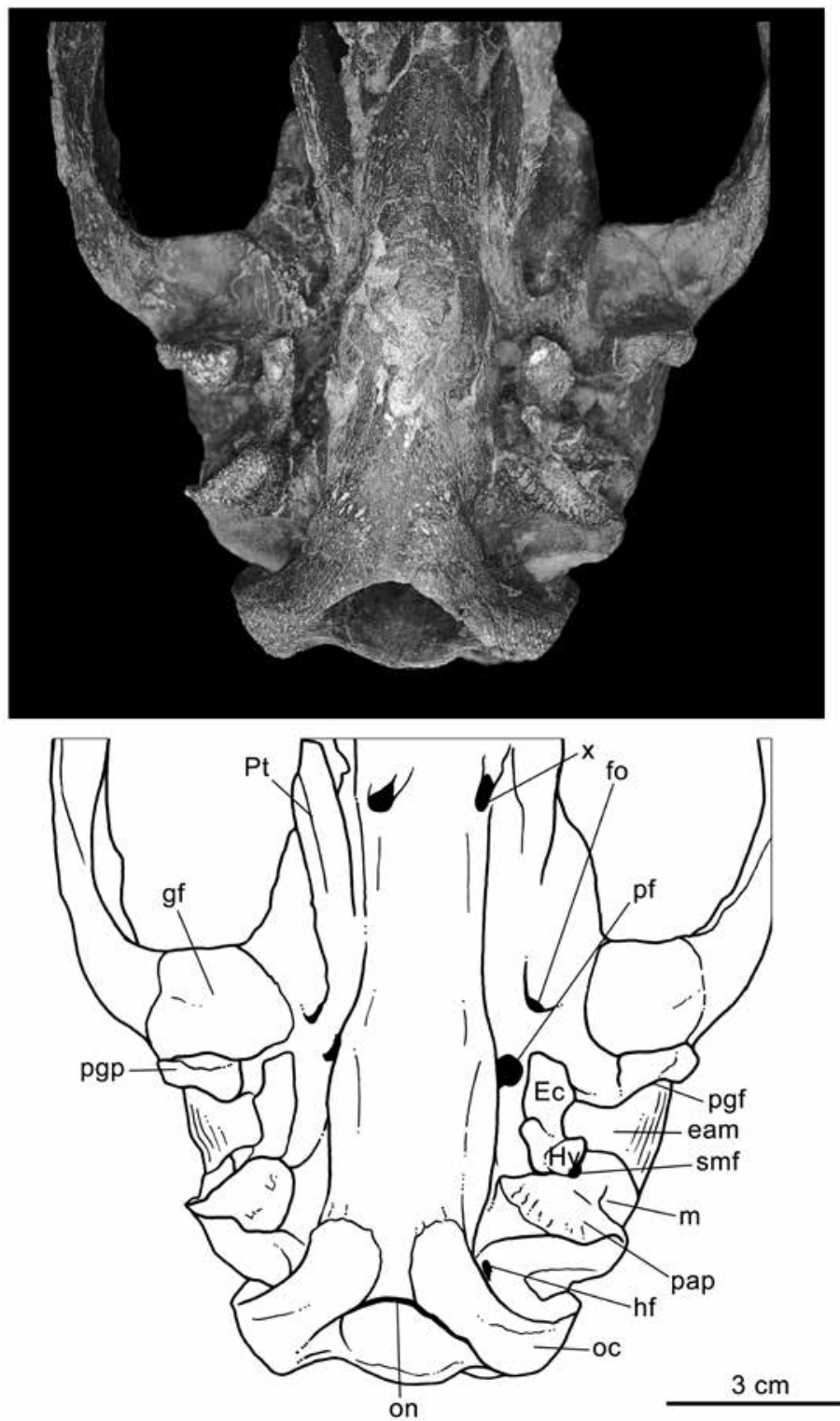

FIG. 15. Posterior portion of skull of Huayqueriana cf. H. cristata IANIGLA-PV 29, in ventral view. Abbreviations: eam, external acoustic meatus; Ec, ectotympanic; fo, foramen ovale; gf, glenoid fossa; hf, hypoglossal foramen; Hy, hyoid (tympanohyal + stylohyal); m, mastoid process of petrosal; oc, occipital condyle; on, odontoid notch; pap, paracondylar process of exoccipital; pf, piriform fenestra; pgf, postglenoid foramen; pgp, postglenoid process; Pt, pterygoid; smf, stylomastoid foramen. Letter $\mathbf{x}$ identifies canal X for nerve of pterygoid canal and vascular structures (see text). Faintly visible on the specimen's left side is the large sulcus running between the piriform fenestra and canal $\mathrm{X}$. 

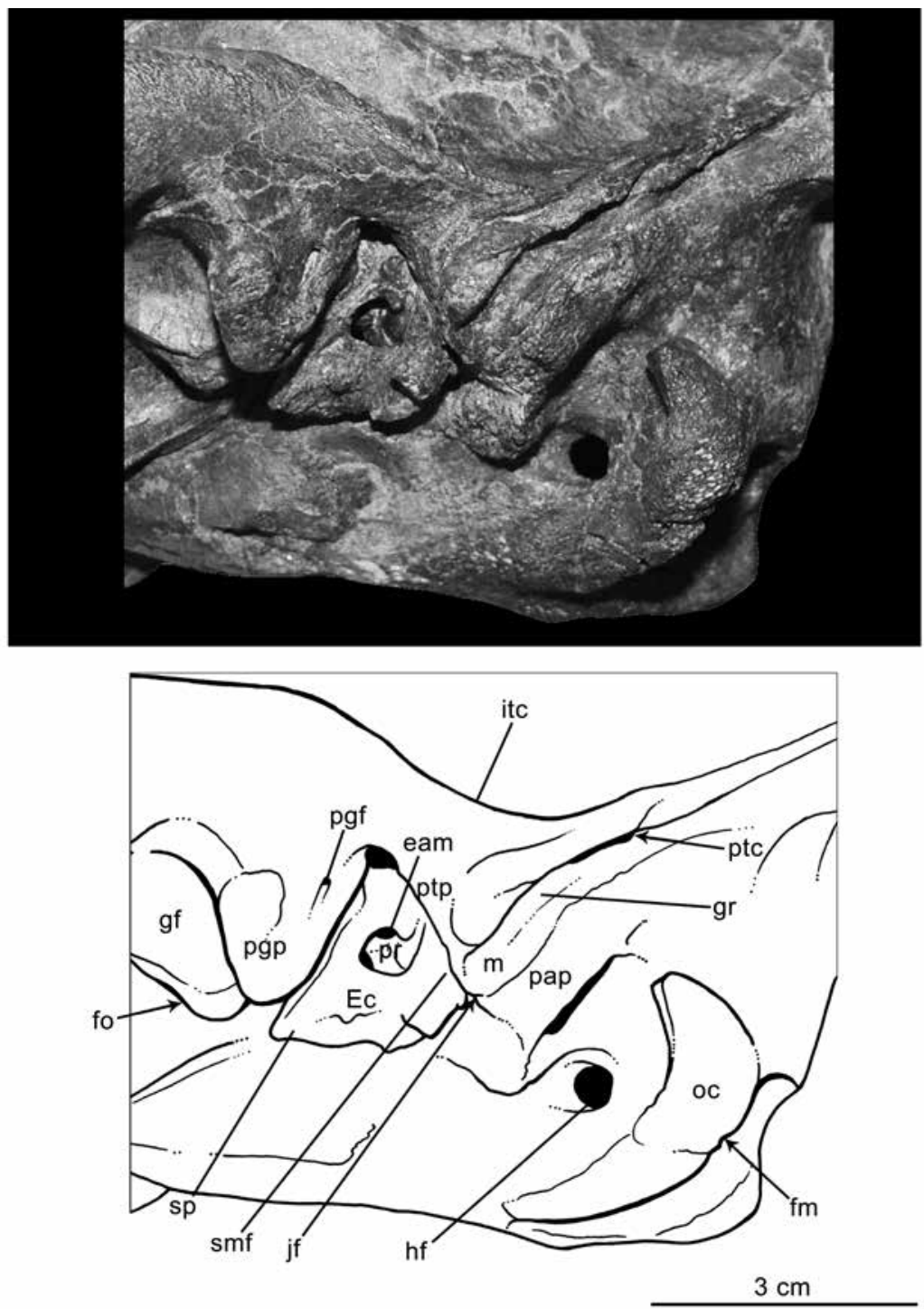

FIG. 16. Posterior portion of skull of Huayqueriana cf. H. cristata IANIGLA-PV 29, in left ventrolateral view. Abbreviations: eam, external acoustic meatus; Ec, ectotympanic; fm, foramen magnum; fo, to foramen ovale; gf, glenoid fossa; gr, occipital groove; hf, hypoglossal foramen; itc, infratemporal crest; jf, to jugular foramen; m, mastoid process of petrosal; oc, occipital condyle; pap, paracondylar process of exoccipital; pgf, postglenoid foramen; pgp, postglenoid process; pr, promontorium; ptc, posttemporal canal; ptp, posttympanic process of squamosal; smf, stylomastoid foramen; sp, styliform process of ectotympanic. 
became more pronounced with age. In the examined macraucheniines, a longitudinal crest is present in Pr. antiquua, Pr. calchaquiorum, and $S$. bravardi (figs. 7B, C, 9C). Despite the advanced ontogenetic stage of IANIGLA-PV 29, this feature is either negligible or absent.

The glenoid fossa is small and nearly circular. The postglenoid (= retroarticular) process is slightly wider than tall and pierced by a large postglenoid (= retroarticular) foramen as seen in posterior view (figs. 15,16$)$. The posttympanic (= retrotympanic) process of the squamosal is short and appressed to the mastoid process of the petrosal as in Theosodon (Scott, 1910), M. patachonica, $S$. bravardi (= processus retrozygomaticus of Rusconi, 1932), O. zeballosi (MHIN-UNSL-GEO-V 465a), and Pr. calchaquiorum. The posttympanic process is separated by a deep sulcus (see below) from the occipital paracondylar process (= paraoccipital process of Scott, 1910; Rusconi, 1932; Fernández de Álvarez, 1940).

The wide foramen ovale (figs. 13E, 15, 16) lies medial to the glenoid cavity and faces forward and downward. This opening has been previously identified in other macraucheniids as the foramen rotundum (Rusconi, 1932) or a confluent foramen ovale/rotundum (Scott, 1910). From examination of the endocast, we conclude that the only nerve piercing this opening was $\mathrm{CN} \mathrm{V}_{3}$, in agreement with observations by Simpson (1933) and Fernández de Álvarez (1940) for other macraucheniines. Huayqueriana and its allies studied to date evidently lacked a separate foramen rotundum (see also Cerebral Endocast) and the foramen rotundum was confluent with the sphenoorbital foramen.

On either side of the interpterygoidal space on the ventral surface of IANIGLA-PV 29, there are two prominent features. One is a pronounced groove running from the piriform fenestra along the medial side of the pterygoid process to a large canal (canal X; asterisk in fig. 15). Canal X perforates the lateral margin of the central stem close to the original location of the basisphenoid/presphenoid synchondrosis. As large apertures situ- ated in or near the mesocranial portion of the central stem are rare or absent in other mammals, we at first thought they were simply artificial dehiscences into the large pneumatic cells penetrating the sphenoid complex. Comparison with other macraucheniid specimens convinces us that they are original, although we have not been able to fully resolve what they carried, as the following discussion illustrates.

In IANIGLA-PV 29 (figs. 13B, 17B-D), canal $\mathrm{X}$ is more or less vertically oriented and apparently opened within the floor of the orbit. Because of preparation artifacts as well as the condition of the orbital areas in the specimen, the precise position of the dorsal ports for these canals is uncertain. Similar openings are seen in Pr. antiquua MACN-PV 7986 (fig. 7B), but they are situated much more caudally, at the level of foramen ovale, where they penetrate the pterygoid processes. From the morphological standpoint they are similar, however, in that they run within the interpterygoidal or pharyngeal portion of the basicranium. In other specimens, such as Pr. calchaquiorum MACN-PV 5528, Promacrauchenia sp. MLP 29-X-10-16, and S. bravardi MACN-PV 13082, basicranial damage is extensive and it cannot be determined whether similar canals existed in these specimens, although the deep grooves emanating from the piriform fenestra are present. In her description, Fernández de Álvarez (1940) made mention of these apertures in $M$. patachonica MACN-PV 2 and interpreted them as channels for the auditory (= Eustachian) tubes, but this cannot be correct because they are situated well rostral to the middle ear and in any case pass into, not out of, the cranium (in her pl. 2, however, the arrow for "trompa de Eustaquio" is shown as emanating from damaged pneumatic cells in the pterygoid plate, which does not agree with her description).

Nor can canal X be the homolog of the alisphenoid canal of other mammals. The alisphenoid canal for the maxillary artery (or a branch derived therefrom) has an anterior and posterior opening, although the anterior opening may 
merge with the sphenoorbital fissure or foramen rotundum and the caudal opening is frequently found in a common depression with the foramen ovale (e.g., Wible and Spaulding, 2013, and references herein cited). Moreover, a well-defined groove creasing the lateral aspect of the alisphenoid, in the form of a sulcus rather than a tube, was found in all members of the comparative set in which this area was represented, except for the S. bravardi MACN-PV 13082. If this channel did not conduct the maxillary artery per se, it may have transmitted a meningeal branch of the latter through foramen ovale. Apart from Macraucheniidae, the groove in the alisphenoid is also seen in the Santacrucian proterotheriid Tetramerorhinus cingulatum MACN-A 5971. In this specimen there is also a relatively small aperture in the position of canal X.

What, then, is canal $\mathrm{X}$ and what is the relationship between it and the groove emanating from the piriform fenestra? We may begin with the identity of the latter. Although certainty is not possible, we infer from comparative considerations (MacPhee, 1981) that it probably housed the nerve of the pterygoid canal. This nerve, which transmits autonomic fibers related to the pterygopalatine ganglion (Hiatt and Gartner, 2001), usually runs within or along the pterygosphenoid suture to penetrate the rear wall of the pterygopalatine fossa, and it is always small in caliber. The unusual width of the groove in macraucheniines suggests that it may have conducted something in addition. The essential basis for this assumption is as follows. Although canal X is differently positioned in IANIGLA-PV 29 and in Pr. antiquua MACN-PV 7986, in both specimens it is very large, much larger than would be necessary to transmit the nerve of the pterygoid canal alone. This can best be accounted for by assuming that the canal transmitted a hypertrophied vidian artery and perhaps also an associated vein. Other possibilities exist, such as an anastomotic branch from the ascending pharyngeal, but in view of the thinness of the evidence we prefer to simply name the inferred vessel the vidian or artery of the pterygoid canal, without settling its homology. In the case of the latter specimen the apertures are also situated where one would expect the pterygoid canal to lie, i.e., at the junction of the central stem and dorsal sutural surface of the pterygoid.

Furthermore, because the fossa for the pterygopalatine ganglion is situated in close relation to the floor of the orbit, conditions in Huayqueriana would conform to those in other mammals if the nerve of the pterygoid canal simply ran across the opening of canal X to enter the pterygopalatine fossa. This does not, however, explain the comparatively large size of canal $\mathrm{X}$ nor its connection with the orbit. Intact vidian arteries in the adult stage are rare (or rarely identified) in mammals (MacPhee, 1981). Apparently even rarer is the situation in which the vidian forms an anastomotic link (arteria anastomotica) between the petrosal or cerebral portion of the internal carotid and the maxillary artery of the external carotid (De La Torre and Netsky, 1960). Typically, however, arteriae anastomoticae (which may arise in several different ways) do not possess their own foramina, but make their connections via foramen ovale. In artiodactyls such linkages, together with other associated retia, are thought to function as a countercurrent selective brain-cooling mechanism, with heat energy transferred from warm arterial blood to cooler venous blood (Caputa, 2004). Whether such a mechanism existed in Huayqueriana or other macraucheniines is unknown and perhaps unknowable, as retia normally do not leave any diagnostic osseous indications of their existence (H. O’Brien, 2013, personal commun.). Phylogenetic bracketing does not resolve the issue, except in a negative sense, because cranial retia have not been identified in extant perissodactyls (Daniel et al., 1953; but see Du Boulay, 1999).

The jugular foramen (= foramen lacerum posterius; Fernández de Álvarez, 1940) is small and constricted. It opens rostroventrally, between the paracondylar process and the petrosal, and is hidden by the former in ventral view (fig. 16). There is a large piriform fenestra (= foramen lacerum anterius; Scott, 1910; Rusconi, 1932, Fernández de 
Álvarez, 1940) (fig. 15), which intervenes between the anterior pole of the petrosal and the trailing edge of the alisphenoid (MacPhee, 1981). As in extant perissodactyls (e.g., Equus; Sisson and Grossman, 1975), the medial side of the petrosal is separated from the bones of the central stem by a broad fissure. This hiatus is continuous with the more medially situated piriform fenestra. Huayqueriana is similar, although the petrosal forms a tighter junction caudally with the basioccipital than in extant perissodactyls.

Although a separate opening for the internal carotid was not identifiable, the vessel may well have been present judging from comparative data on a variety of SANUs (Billet and Muizon, 2013; MacPhee, 2014; but for conditions in extant perissodactyls see Du Boulay, 1991). If present in the adult stage, it presumably passed into the endocranium through the piriform fenestra. However, no specific osteological features could be identified in CT scans that might support such an inference (MacPhee, 2014; Billet et al., 2015; see also Petrosal), although it is important to note that a certain amount of bone was lost during preparation in the relevant region.

The hypoglossal foramen (= condylar foramen of Scott, 1910; Rusconi, 1932; Fernández de Álvarez, 1940) is single and large, as in all macraucheniine specimens examined. It opens within a depression in front of the condyles, by which it is hidden in ventral aspect (fig. 15).

The occipital condyles are partially eroded and slightly dorsoventrally compressed in IANIGLAPV 29. In lateral view (fig. 3A), the condyles do not reach the transverse level of the nuchal crest, differing in this regard from $X$. bahiense, W. delacroixi, and M. patachonica, whose condyles protrude beyond this level. In ventral view (fig. 3C), the condylar articular facets extend rostrally onto the basioccipital and are separated at the midline, similar to other macraucheniids (e.g, Theosodon, Cr. normalis, S. bravardi, Pr. antiquua, and $M$. patachonica; Scott, 1910; Rusconi, 1932; Dozo and Vera, 2010). The odontoid notch between the condyles is U-shaped, as in Pr. calchaquiorum (fig. 7C). This notch is narrower and V-shaped in Pr. antiquua (fig. 7B), S. bravardi (fig. 9C), W. delacroixi, X. bahiense, and $M$. patachonica (Fernández de Álvarez, 1940). The foramen magnum is circular and directed caudoventrally.

The paracondylar process is broken on both sides of the skull. It is lateromedially wider than rostrocaudally long, and curves slightly rostrally. This process is more vertical and ventrally projecting in Pr. antiquua (fig. 5B), S. bravardi (fig. 9C), and M. patachonica (Fernández de Álvarez, 1940). In these species it protrudes below the plane of the basicranium.

In posterior view, the occipital is high, triangular, and ventrally broad (fig. 18). There is a vertical ridge descending from the nuchal crest, separating two lateral depressions that are laterally bordered by blunt occipital protuberances. The development of the occipital crest and associated protuberances varies among the specimens compared. In analogy to the horse, the bilateral depressions immediately under the nuchal crest and occipital protuberances should represent attachment points for the tendons of semispinalis capitis muscles (Sisson and Grossman, 1975).

The mastoid portion of the petrosal is wedged between the posttympanic and paracondylar processes, as in other litopterns (Scott, 1910; Rusconi, 1932; Soria, 2001). Between the mastoid and the paracondylar process there is a deep, almost vertical sulcus, the occipital groove, leading to the posttemporal canal, level with the dorsal border of the condyle (fig. 18). An opening in a similar position was described for S. bravardi (= mastoid foramen of Rusconi, 1932) and can be seen in the holotype of $H$. cristata as well as O. zeballosi MHIN-UNSL-GEO-V 465a, Pr. antiquua, and M. patachonica MACN-PV 2. As in other SANUs (MacPhee, 2014), the posttemporal canal, a primitive feature that transmits the arteria diploëtica magna in a diverse array of mammals (Wible, 1987), is confluent with the transverse sinus, which is mostly enclosed by bone and very large in Huayqueriana (figs. 11, 17A). In all probability the canal transmitted both an artery and a vein. 


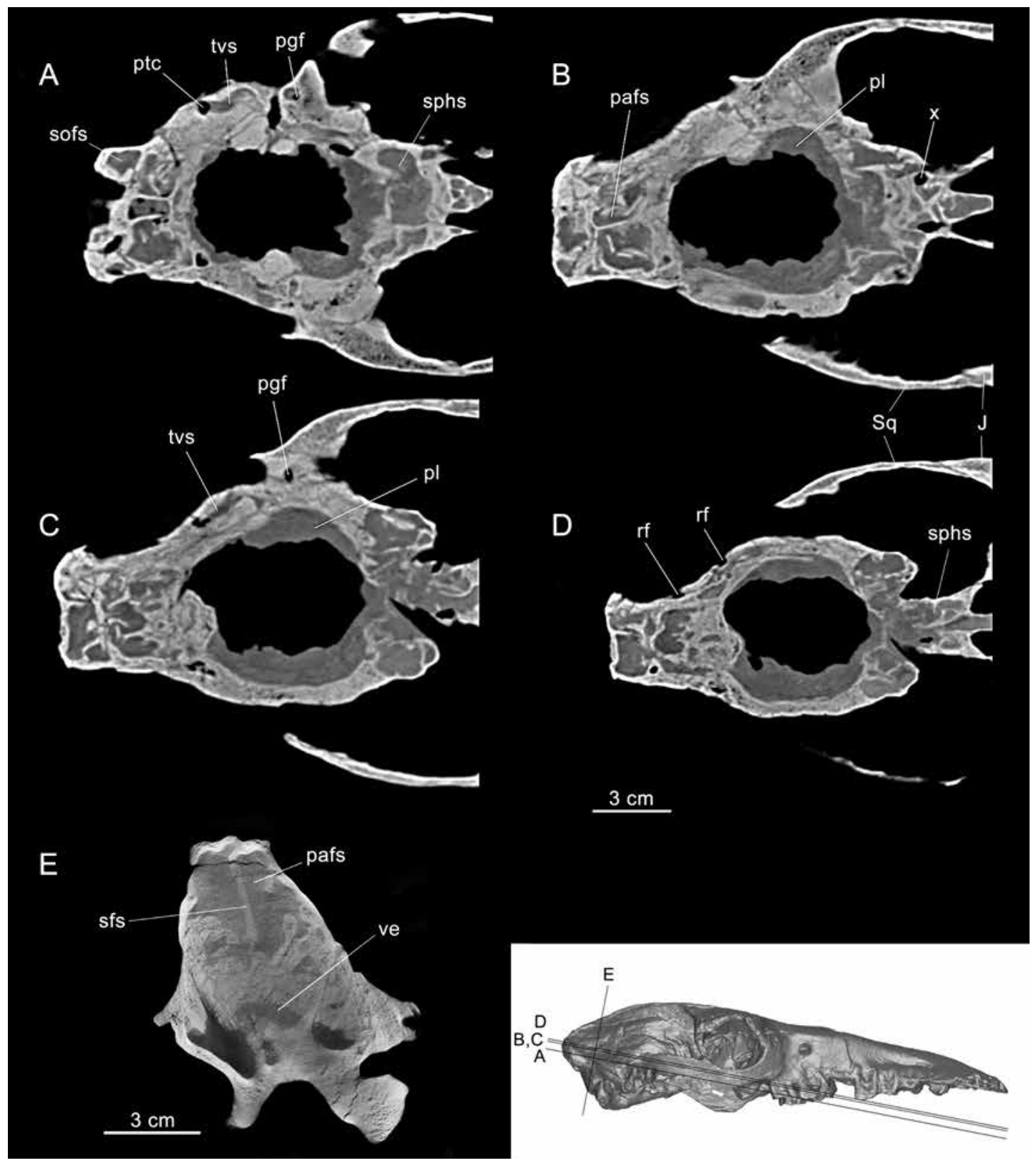

FIG. 17. A-E, Virtual subhorizontal and subcoronal sections of skull of Huayqueriana cf. $H$. cristata IANIGLA-PV 29. Abbreviations: J, jugal; pafs, parietal extension of frontal sinus; pgf, postglenoid foramen; pl, position of piriform lobe; ptc, posttemporal canal; rf, foramina for rami temporales; sfs, septum sinuum frontalium; sofs, supraoccipital extension of frontal sinus; sphs, sphenoidal sinus; Sq, squamosal (zygomatic process); tvs, transverse sinus canal; ve, position of vermis. Letter $\mathbf{x}$ identifies canal X for nerve of pterygoid canal and vascular structures (see text). 
It may be briefly noted that, although the posttemporal canal is located much more laterally and ventrally in macraucheniines than in notoungulates (MacPhee, 2014), in the latter group it has the same relationship with the petrosal and occipital, and connects with the transverse sinus in the same way. Thus, we see no reason to question the homology of these openings in the different SANU orders.

IANIGLA-PV 29 exhibits an extra opening on the nuchal crest, probably a venous channel, at a more dorsal level on the occipital (fig. 18). Intracranially this canal is of small diameter and separate from the posttemporal canal. In dogs the named mastoid foramen transmits the occipital emissary vein, which drains the deep muscles of the neck into the sigmoid sinus (Evans, 1993), but the homology of this vessel in SANUs is problematic. As far as could be determined, this second aperture on the nuchal crest of IANIGLA-PV 29 is absent in the other macraucheniine specimens examined.

\section{MidDle EAR}

The volume enclosed by the tympanic cavity is comparatively small in relation to skull size (fig. 19A). Its limits are difficult to reconstruct since much of the tympanic floor was evidently membranous and the area has been extensively prepared. Apart from the proximal hyoid (tympanohyal + stylohyal), the only element present for certain in the floor is the ectotympanic, which is preserved on both sides of the skull (fig. 15). The external acoustic meatus (fig. 15) is similar in width to that of the holotype of $H$. cristata (fig. 2C) and Pr. calchaquiorum (fig. 7C). In Pr. antiquua (fig. 7B) and M. patachonica, meatal width is somewhat greater.

Eстотумpanic: As in Rhinoceros and Tapirus (van Kampen, 1905), as well as in other litopterns in which the ectotympanic is known (e.g., Epitherium laternarium [Soria, 2001]; Theosodon [Scott, 1910: pl. XVII]; Huayqueriana cristata holotype), this element in IANIGLA-PV 29 is only vaguely crescentic, lacking significant medial and lateral flanges and forming neither an enclosing bulla nor a well-defined external acoustic meatus. In this regard litopterns are quite different from notoungulates (Patterson, 1932, 1934; Gabbert, 2004; MacPhee, 2014; Forasiepi et al., 2015b).

The rostral and caudal crura of the ectotympanic meet the alisphenoid in front and the mastoid/hyoid and paracondylar process behind, respectively, as in the holotype of $H$. cristata. In ventral view (fig. 15), the ectotympanic has three small, blunt protuberances, described further below. In front, a large process protrudes rostroventrally, as in the holotype of $H$. cristata, and exhibits a foramen at its base. Just caudal to this is another small process, broken on the left side, that points toward the meatus. The rearmost protuberance is medially oriented.

Related to these processes is the stump of the hyoid apparatus, which is closely appressed to the ectotympanic's caudal crus. Given its position it helps to delimit, together with the mastoid and paracondylar processes, an incomplete stylomastoid foramen for the exit of CN VII. This area is also the only place where the ectotympanic seems to have been attached to the skull (fig. 19A, left side). Whether there was also a rostral attachment to the anterior process of the malleus (= folian process), as occurs in Rhinoceros and Tapirus (van Kampen, 1905), cannot be determined. Although there must have been a tympanic membrane closing off the lateral aspect of the middle ear, its line of attachment on the ectotympanic is not obvious. The medial border of the left ectotympanic is slightly inflected for a short distance (fig. 19A, feature 2); this may represent the tympanic crest to which the membrane characteristically attaches in mammals.

On the same side there is another process (fig. 19A, feature 1) which extends in the form of a thin plate. The level of resolution in the illustrated segment is such that it cannot be determined whether this plate is ectotympanic or petrosal in origin, or something else entirely, such as an entotympanic. Although an entotympanic occurs in extant Rhinoceros, Equus, and possibly Tapirus 

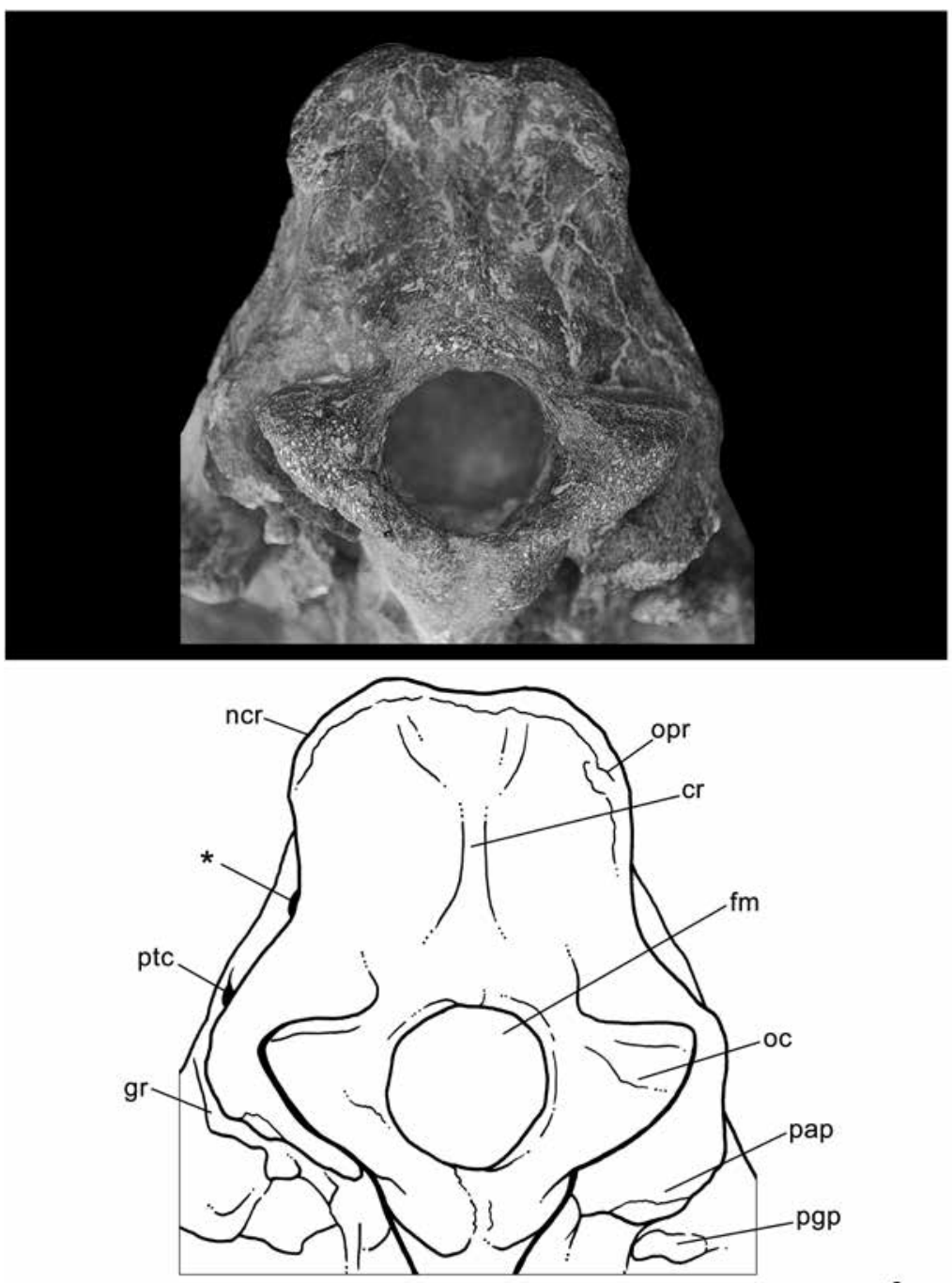

FIG. 18. Occipital view, skull of Huayqueriana cf. H. cristata IANIGLA-PV 29. Abbreviations: cr, crest; fm, foramen magnum; gr, occipital groove; ncr, nuchal crest; oc, occipital condyle; opr, occipital protuberance; pap, paracondylar process of exoccipital; pgp, postglenoid process; ptc, posttemporal canal. Asterisk $\left(^{\star}\right)$ identifies canal for vascular structures (see text).

(van Kampen, 1905; Maier et al., 2013), and apparently also in the notoungulate Cochilius (MacPhee, 2014), any conclusion concerning Huayqueriana will have to await better material.

In IANIGLA-PV 29, there is evidence that parts of some auditory ossicles were preserved. On the specimen's right side, a small piece of bone projects laterally from fenestra vestibuli (fig. 19B). It connects with a second piece, the dorsal end of which is lodged in a small depression on the tympanic roof medial to the crista parotica. Resolution is poor, but it seems plausible that the features seen on the scans include one of the stapedial crura and the incudo-stapedial joint. This is the only known example of ossicle preservation in a litoptern. 

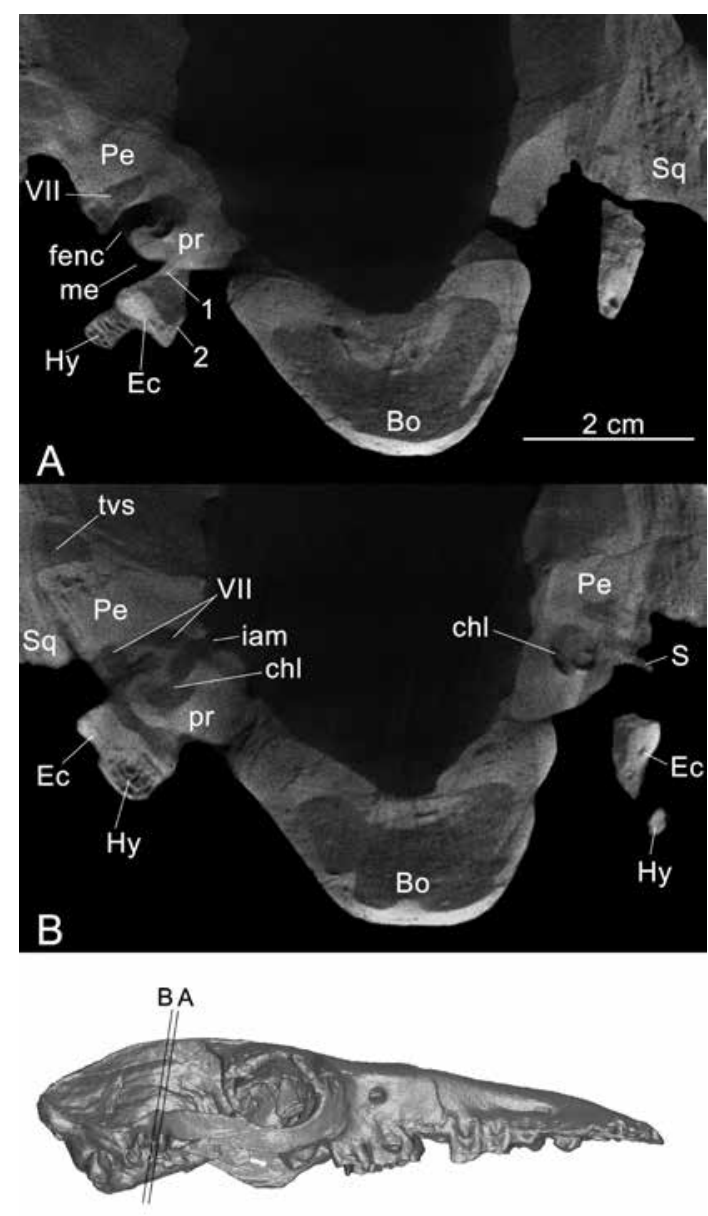

FIG. 19. A-B, Virtual subcoronal sections of basicranium of Huayqueriana cf. H. cristata IANIGLA-PV 29. Abbreviations: Bo, basioccipital; chl, cochlea; Ec, ectotympanic; fenc, fossula fenestrae cochleae; $\mathbf{H y}$, hyoid (tympanohyal + stylohyal); iam, internal acoustic meatus; me, middle ear space; Pe, petrosal; pr, promontorium; S, stapes; Sq, squamosal; tvs, transverse sinus; VII, passageway of the facial nerve (CN VII); 1, RTPP contacting ectotympanic; 2, crista tympanica?

Petrosal: As the density contrast in CT segments was low, we were unable to produce highquality virtual 3D reconstructions of the petrosal. However, the tympanic, oblique, and cerebellar views of the reconstructed right petrosal presented in figure 20 are adequate for illustrating and describing principal anatomical features (fig.
$20 \mathrm{~A}$ is provided with an orientation guide). In order to adequately visualize deeply recessed features in tympanic or ventral aspect, it was necessary to virtually cut away much of the crista parotica, pars canalicularis, and tympanic floor (tympanohyal, ectotympanic). However, most of these features can be seen in section in the segmental views (fig. 19). The aperture in the lateral sidewall of the promontorium (asterisk in fig. $20 \mathrm{~A}, \mathrm{~B})$ is a preparation artifact, not a preexisting structure. It opens into the cochlear canal.

The rounded promontorium, housing the cochlea (e.g., MacIntyre, 1972; Meng and Fox, 1995), dominates the tympanic aspect (fig. 20A). The lateral and caudal surfaces of the promontorium are interrupted by the fenestra vestibuli and the fossula fenestrae cochleae, respectively. The fenestra cochleae, which is situated within the fossula and is not externally visible from this angle (MacPhee, 1981), internally supports the secondary tympanic membrane. The fenestra cochleae is separated from the fenestra vestibuli by a thick, semivertical crista interfenestralis. The fenestra vestibuli, which holds the footplate of the stapes in life, is similar in area to the fenestra cochleae. The stapedial ratio $(\sim 1.8)$ is larger than that of other litopterns that have been examined, including Macrauchenia (1.5; Billet et al., 2015).

The caudal end of the tympanic cavity is capacious, but no features associated with it (e.g., stapedius muscle fossa, fossa incudis) can be securely identified on the reconstruction. Because the line of the cut through the mastoid area passes through this region, it is not evident that it is, in fact, framed by the petrosal (in the form of the caudal tympanic process of the petrosal, CTPP).

Rostromedially, there is a very low, discontinuous crest on the ventral surface of the promontorium that continues onto its medial side. Inspection of relevant segments indicates that the arc of curvature of the crest corresponds to that of the medial margin of the ectotympanic, and that the two were in close contact during life. This feature may therefore be identified as a rather insignificant rostral tympanic process of 
the petrosal (RTPP), the ventral edge of which helped to form the tympanic/petrosal suture. A somewhat more developed crest is seen in a similar position in Paleogene litoptern fossils referred to Miguelsoria (Billet et al., 2015). The RTPP has been identified in a wide variety of mammals (e.g., MacPhee, 1981; Wible 2003, 2008, 2012), although the derived eutherian condition, in which the process forms most or all of a well-developed bulla, is largely limited to primates and possibly some of their close relatives.

Medial to the RTPP, on the medial edge of the petrosal, there is shallow groove that may have held the inferior petrosal sinus (SIPS). This structure is very common in mammals, as the sinus is the major connector between pharyngeal venous plexuses, the cavernous sinus, and the internal jugular vein on the ventral surface of the skull. Salient crests bordering a similar sulcus have been described for Miguelsoria (Billet et al., 2015).

The area immediately lateral to the preparation artifact in IANIGLA-PV 29 is also damaged (fig. 20B), and in order to visualize structures it was necessary to digitally open up the area related to the cavum supracochleare (for the geniculate ganglion and first part of the facial nerve). Two sulci emerge from the cavum supracochleare, one running caudomedially to the incomplete stylomastoid foramen (sulcus for the facial nerve), and the other, deeper groove running rostrolaterally to the hiatus Fallopii (hiatus for the greater petrosal nerve). The foramen faciale (FF), the aperture in the tympanic roof by means of which the second or tympanic part of the facial nerve enters the true tympanic cavity from the cavum supracochleare, is represented in the reconstruction by a notch corresponding to the foramen's dorsal border (fig. 20B).

The cerebellar view of the petrosal (fig. 20C) is dominated by two main structures: the internal acoustic meatus (IAM) rostrally and the subarcuate fossa (SAF) in the caudal part of the bone. The deep meatus is subdivided as usual into the superior acoustic foramen (FAS) laterally and the inferior acoustic foramen (FAI) medially (fig. 20C), the two being separated by a thick crista transversa. In Miguelsoria (Billet et al., 2015) the IAM appears to have been shallower. The FAS splits into two openings: a large rostral aperture, leading to the cavum supracochleare, for the facial nerve (CN VII); and a smaller caudal opening corresponding to the channel for a branch of the vestibular nerve (CN VIII), which innervates the membranous labyrinth (e.g., Wible, 2003). The FAI also subdivides into a large rostral aperture for bundles of the vestibular nerve and a smaller caudal area perforated by many small foramina (cribriform tract, for fascicles of the cochlear nerve). The caudal border of the internal acoustic meatus bears a tiny aperture that presumably corresponds to the foramen singulare for passage of some fibers of the vestibular nerve (CN VIII) (Meng and Fox, 1995).

The subarcuate fossa, as seen in the 3D model of the petrosal (fig. 20C), is even shallower than in the material referred to Miguelsoria (Billet et al., 2015). This is in agreement with the small size of the cast of the cerebellar paraflocculus, the structure that it would have housed in life (e.g., MacIntyre, 1972) (see Endocast).

The external opening of the cochlear canaliculus (= aqueductus cochleae) for the perilymphatic duct (see Osseous Inner Ear) is small and located on the medial side of the petrosal, in relation to the notch marking the border of the jugular foramen. A single cochlear canaliculus is present in IANIGLA-PV 29, differing from some specimens referred to Miguelsoria in which there is a small accessory aperture (probably vascular) accompanying the cochlear canaliculus (Billet et al., 2015).

\section{OSSEOUS INNER EAR}

The endocast of the left osseous labyrinth of IANIGLA-PV 29 is illustrated in figure 21. As in all mammals, the labyrinth consists of a series of interconnected spaces within the petrosal, including the cochlea, vestibule, and the three semicircular canals (e.g., MacIntyre, 1972; Ekdale, 2013, 2016). The cochlear canal 

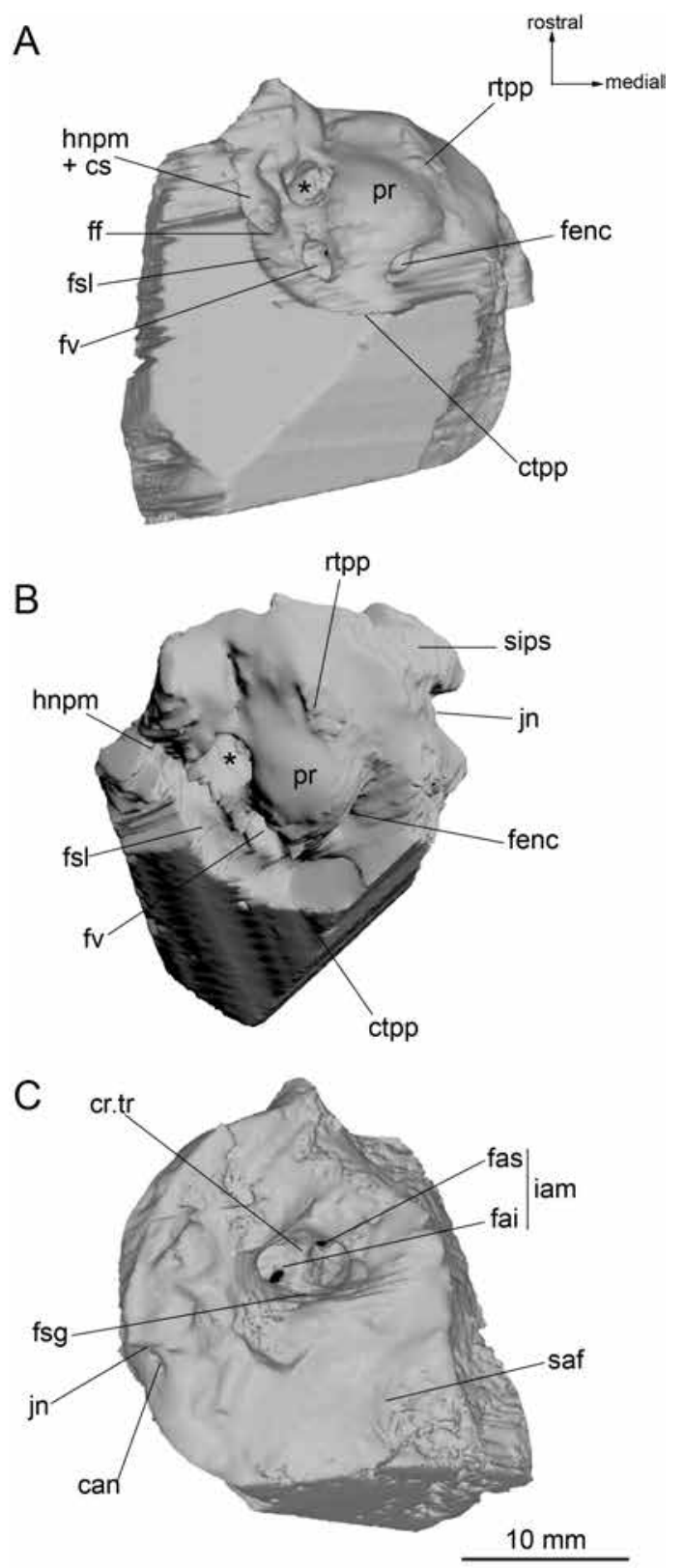

forms the largest part of the osseous labyrinth by volume (table 3 ). The canal is coiled in Huayqueriana, as is universally the case in therians (Luo et al., 2010); it expresses a total helical rotation of $795^{\circ}$, equivalent to 2.2 full turns (fig. 21F; table 3). All litopterns measured to date exhibit similar values, including Early Eocene taxa (2.25 to 2.4 turns), "Proterotherium"2 (2.1), Diadiaphorus (2.25), and Macrauchenia (2.3) as measured by Billet et al. (2015). The notoungulates Notostylops (2.25; Macrini et al., 2010) and Hegetotherium (2.5; Simpson, 1936; Macrini et al., 2010) are also similar, whereas in some other notoungulates (Altitypotherium, Pachyrukhos, and Cochilius) the degree of coiling is less, 2 turns (Macrini et al., 2013).

The first half of the basal cochlear turn is not tightly appressed to the rest of the coil, which is a similarity to conditions previously described for other litopterns (Billet et al., 2015). By contrast, succeeding turns are tightly packed. The primary and secondary osseous spiral laminae, the presence of which is a plesiomorphic therian trait (Meng and Fox, 1995), incompletely separate the cochlear canal into two parts, the scala tympani and scala vestibuli. In IANIGLA-PV 29 the primary lamina is represented by a feeble groove on the inner wall of the cochlea, while the deeper secondary lamina on the outer surface of the spiral can be seen along the basal turn to a point $\sim 510^{\circ}$ away from the fenestra cochleae (i.e., $0^{\circ}$ ) (fig. $21 \mathrm{E}$ ), similar to other litopterns (Billet et al., 2015). In profile, the cochlea of IANIGLA-PV 29 has a height that is about twothirds of its width (table 3 ).

\footnotetext{
2 Identified as Proterotherium by Billet et al. (2015), but see taxonomy in Soria (2001). In view of the taxonomic uncertainty surrounding the allocation of the specimens studied, it is here referred to as "Proterotherium."
}

FIG. 20. Model of right petrosal of Huayqueriana cf. H. cristata IANIGLA-PV 29, based on 3D reconstructions from micro-CT data, in $\mathbf{A}$, tympanic, $\mathbf{B}$, oblique, and $\mathbf{C}$, cerebellar views. In order to adequately expose the facial sulcus (fsl) and track of the greater petrosal nerve (hnpm), it was necessary to digitally remove the bone obscuring structures, including the sidewall of the cavum supracochleare (cs) (see text). Other abbreviations: can, external aperture of cochlear canaliculus; cr.tr, crista transversa; ctpp, caudal tympanic process of petrosal; fai, inferior acoustic foramen; fas, superior acoustic foramen; fenc, fossula fenestrae cochleae; ff, foramen faciale; fsg, foramen singulare; fv, fenestra vestibuli; iam, internal acoustic meatus; jn, notch for jugular foramen; pr, promontorium; rtpp, rostral tympanic process of petrosal; saf, subarcuate fossa; sips, sulcus for inferior petrosal sinus. Asterisk $\left({ }^{*}\right)$ indicates preparation artifact. 
TABLE 3

Linear and angular measurements of the digital inner ear of Huayqueriana cf. H. cristata (IANIGLA-PV 29) Abbreviations: L, length; W, width.

\begin{tabular}{|c|c|}
\hline Number of cochlear turns ${ }^{1}$ & 2.2 \\
\hline Cochlea height & $3.93 \mathrm{~mm}$ \\
\hline Cochlea width & $5.77 \mathrm{~mm}$ \\
\hline ASC L/ ASC W² & $7.84 \mathrm{~mm} / 7.87 \mathrm{~mm}$ \\
\hline ASC L/W & 0.99 \\
\hline LSC L / LSC W ${ }^{2}$ & $7.09 \mathrm{~mm} / 6.97 \mathrm{~mm}$ \\
\hline LSC L/W & 1.02 \\
\hline PSC L / PSC W² & $7.68 \mathrm{~mm} / 7.71 \mathrm{~mm}$ \\
\hline PSC L/W & 0.99 \\
\hline Angle between ASC and PSC ${ }^{3}$ & $88^{\circ}$ \\
\hline Angle between the PSC and LSC ${ }^{4}$ & $90^{\circ}$ \\
\hline ASC dorsal projection/PSC height ratio ${ }^{5}$ & 0.128 \\
\hline \multicolumn{2}{|c|}{$\begin{array}{l}{ }^{1} \text { Counted following the protocol of West (1985). } \\
{ }^{2} \text { Measurements taken from the inner side of the SC following the protocol of Schmelzle et al } \\
\text { (2007). } \\
{ }^{3} \text { Measured on a plane parallel to the LSC. The origin of the angle is at the crus commune } \\
\text { (Schmelzle et al., 2007). } \\
{ }^{4} \text { Measured on a plane parallel to the ASC (Schmelzle et al., 2007). } \\
{ }^{5} \text { Distance between the dorsal-most point of the ASC to the dorsal-most point of the PSC/ } \\
\text { height of PSC measured in straight line from the LSC to the dorsal-most point of the PSC } \\
\text { (Schmelzle et al., 2007). }\end{array}$} \\
\hline
\end{tabular}

The main axis of the fenestra vestibuli is oriented caudodorsally-rostroventrally, and is positioned ventral and slightly posterior to the lateral ampulla (fig. 21A, C). The external aperture of the fossula fenestrae cochleae is a section of a distorted cone (rather than oval, as usually stated) and larger than that of the fenestra vestibuli, as is also the case in other described litopterns and the notoungulate Notostylops (Macrini et al., 2013; Billet et al., 2015).

The cochlear canaliculus (= aqueductus cochleae), for the membranous perilymphatic duct, opens within the endocranium caudomedial to the fossula fenestrae cochleae. It projects beyond the PSC as seen in dorsal view (fig. 21E), as in other described litopterns and Notostylops (Macrini et al., 2010; Billet et al., 2015), in contrast to Pachyrukhos in which it does not extend as far (Macrini et al., 2013). However, it should be noted that the difference may be size related, in the sense that Pachyrukhos, a very small notoungulate, does not exhibit greatly thickened capsular walls. In consequence, the perilymphatic duct has a shorter journey to the endocranium, reflected in the abbreviated length of its osseous canal.

The vestibule contains the membranous utricule and saccule (Meng and Fox, 1995; Macrini et al., 2010; Ekdale, 2016). In IANIGLA-PV 29 the vestibule is rostrocaudally elongated, parallel to the main axis of the LSC. The recessus sphericus of the vestibule, which contains the saccule in life, forms a significant bulge in the vicinity of the fenestra vestibuli in posteromedial view (fig. $21 \mathrm{D})$. There is a complementary bulge on the utricular side of the vestibule, but it is smaller when seen in lateral view (fig. $21 \mathrm{C}$ ). In posterior view (fig. 21B, D) the canal for nervus ampullaris posterior (CN VIII) runs ventrally from the posterior ampulla to communicate with foramen singulare. The foramen for the superior vestibular area, which conducts the superior part of the 
A

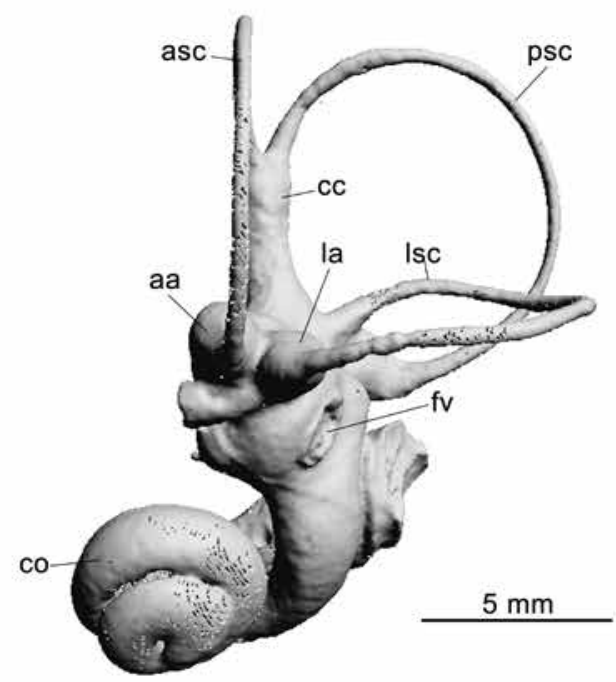

C

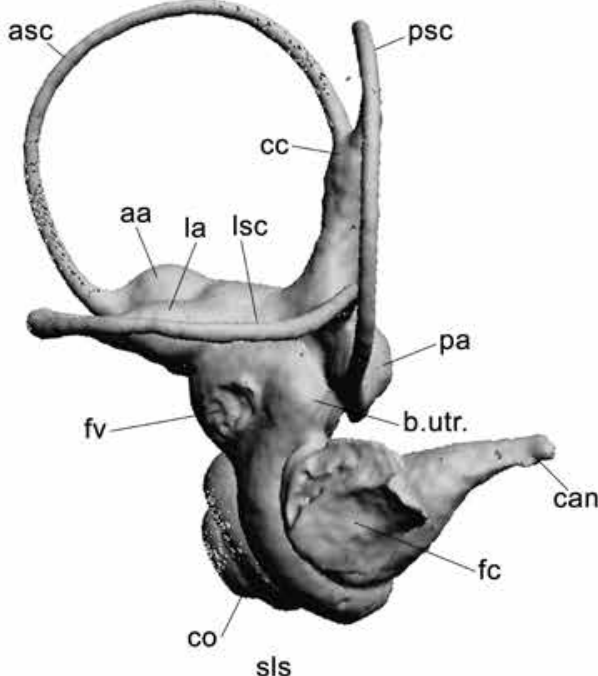

E

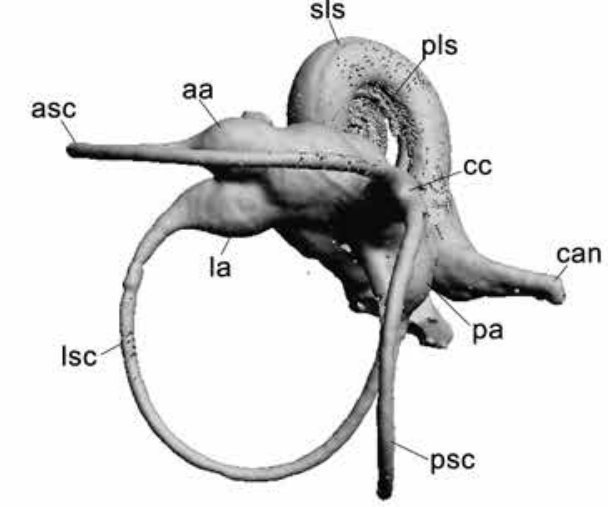

B

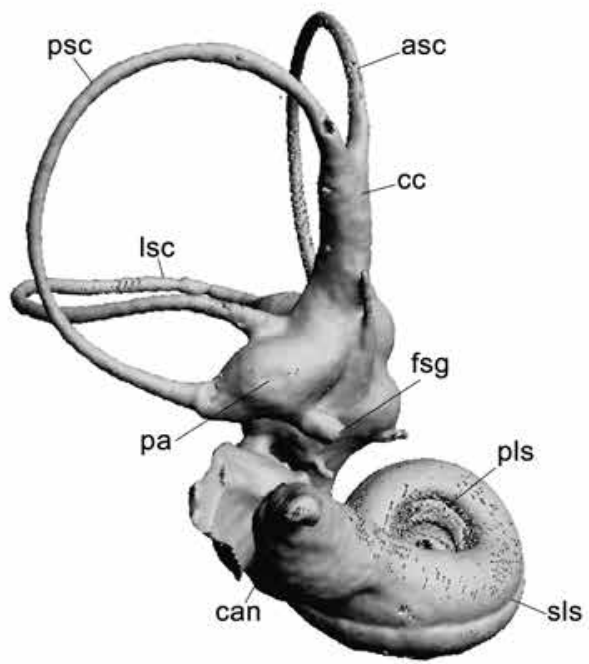

D

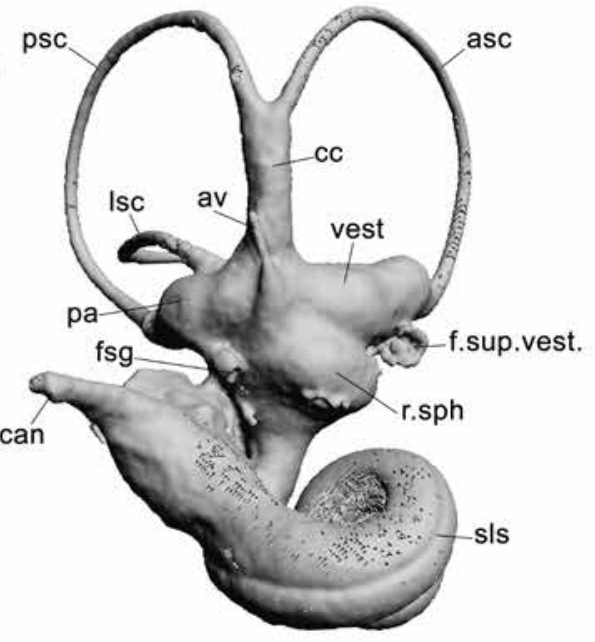

$\mathrm{F}$

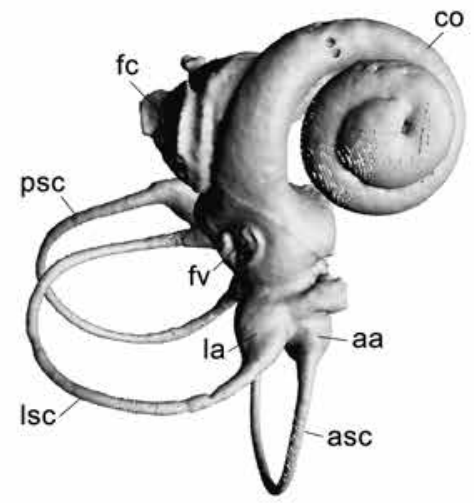


vestibular (utriculoampullary) nerve to the utricular macula, is situated as usual just beneath the ampulla of the anterior semicircular canal (fig. 21D). The narrow aqueductus vestibuli, for the membranous endolymphatic duct, projects dorsally from the vestibule, parallel to crus commune (fig. 21D).

The three semicircular canals are located in the pars canalicularis of the petrosal. The ASC forms part of the rim of the subarcuate fossa, the PSC contributing to its medial border. As in other described litopterns (Billet et al., 2015), the ASC, PSC, and LSC of IANIGLA-PV 29 are notably gracile, much thinner than the crus commune. The ASC and PSC are uniplanar while the LSC is slightly undulating, curving dorsally and then ventrally before connecting to the posterior ampulla (fig. 21B). The semicircular canals are arranged approximately at mutual right angles (table 3). The shape, relative size, and radius of curvature of the semicircular canals vary among litopterns and notoungulates (see Macrini et al., 2010, 2013; Billet et al., 2015).

The arc of the ASC projects slightly above that of the dorsalmost point on the PSC (fig. 21A; table 3), similar to the notoungulate Altitypotherium (Macrini et al., 2013). The degree of projection is apparently greater in Macrauchenia, proterotheriids (e.g., "Proterotherium" and Diadiaphorus; cf. Billet et al., 2015: fig. 17), and the notoungulates Pachyrukhos and Cochilius (Macrini et al., 2013). In dorsal view (fig. 21E), the arc of the LSC is almost level with the lateralmost projection of the PSC, similar to Diadiaphorus and the notoungulates Notostylops, Altitypotherium, and Pachyrukhos, but in contrast to the more extended PSC of "Proterotherium," Macrauchenia, and the notoungulate Cochilius (Macrini et al., 2010, 2013; Billet et al., 2015).
The three ampullae lie in close proximity to the junction of the semicircular canals with the ventricle. The anterior ampulla is on the rostroventral arm of the ASC and dorsolateral to the vestibule; the lateral ampulla is on the anterior arm of the LSC and dorsolateral to the vestibule, and the posterior ampulla is on the ventral arm of the PSC and ventromedial to the vestibule. There is no secondary crus commune (fig. 21B$\mathrm{D}$ ), or the short canal formed by the union of the posterior arm of the LSC and the ventral arm of the PSC (Schmelzle et al., 2007). The secondary crus commune is also absent in Macrauchenia and Diadiaphorus, and the notoungulates Notostylops, Altitypotherium, Pachyrukhos, and Cochilius, but it is present in Early Eocene litopterns (Macrini et al., 2010, 2013; Billet et al., 2015). The secondary crus commune is a plesiomorphic trait for mammals (e.g., Meng and Fox, 1995; Ekdale, 2016), evidently retained in basal litopterns but subsequently lost in later members of the group (Billet et al., 2015).

The crus commune is formed by the posterior arm of the ASC and the anterior arm of the PSC, as in all mammals (Ekdale, 2013). The crus commune is shorter than the length of the two individual SCs, as in other litopterns (excepting some specimens of Miguelsoria in which the ASC but not the PSC is longer; Billet et al., 2015). Among notoungulates the described variation seems to be greater than in litopterns (Macrini et al., 2010, 2013).

\section{Cranial Pneumatization}

In contrast to the relatively small volume of the middle ear, in at least some macraucheniids pneumatization of the cranial vault and basicra-

FIG. 21. Model of osseous labyrinth endocast of Huayqueriana cf. H. cristata IANIGLA-PV 29, based on 3D reconstructions from micro-CT data, in $\mathbf{A}$, anterior, $\mathbf{B}$, posterior, $\mathbf{C}$, lateral, $\mathbf{D}$, posteromedial, $\mathbf{E}$, dorsal, and $\mathbf{F}$, ventral views. Abbreviations: aa, anterior ampulla; asc, anterior semicircular canal; av, aqueductus vestibuli; b.utr., bulge for utriculus; can, cochlear canaliculus; cc, crus commune; co, cochlea; f.sup.vest., foramen for superior vestibular area; fc, fossula fenestrae cochleae; fsg, foramen singulare; fv, fenestra vestibuli; la, lateral ampulla; lsc, lateral semicircular canal; pa, posterior ampulla; pls, primary bony lamina sulcus; psc, posterior semicircular canal; r.sph., recessus sphericus of vestibule (for saccule); sls, secondary bony lamina sulcus; vest, vestibule 
nium is very marked indeed (figs. 10, 11, 17), as originally noted by Rusconi (1932) for S. bravardi MACN-PV 13082. Cranial pneumatization may have reached an ordinal maximum in $M$. patachonica. In M. patachonica MACN-PV 2, the tables of the cranial vault, central stem, pterygoid plates, and lateral aspect of the alisphenoid are all massively inflated (fig. 11). In IANIGLA-PV 29, pneumatization of the vault likewise affects the entire dorsum of the skull, from the frontals to the supraoccipital, although on a smaller scale (figs. 10, 11). Segmental evidence indicates that remodeling activity in the vault proceeded during ontogeny from the paranasal frontal sinuses, which progressively invaded the parietals, squamosals, and supraoccipital. In Huayqueriana (figs. 10,11), the enormous right and left frontal sinuses are separated for their entire length by a septum (septum sinuum frontalium; fig. 17E), as in Equus (Sisson and Grossman, 1975) and probably many other perissodactyls (e.g., tapir; Witmer et al. 1999: fig. 7 ). Although scan resolution is too low for detailed interpretation, pneumatic activity within the basicranium of IANIGLA-PV 29 appears to have spread from the nasopharynx into the bones comprising the central stem, probably via outpocketings from the auditory tube separate from those inflating the middle ear (cf. pneumatization in some other SANU taxa; MacPhee, 2014).

As already mentioned, middle ear pneumatization in Huayqueriana and other Litopterna is not extensive (fig. 19A, B). Although it is frequently stated that litopterns lack an expanded epitympanic sinus (Roth, 1903), this is not the case for all taxa. Rusconi (1932) identified an epitympanic sinus caudodorsal to the external acoustic meatus in S. bravardi. Micro-CT data reveal that Tetramerorhinus also exhibits a small swelling above the tympanic cavity (S. Hernandez del Pino, pers. obs.). The difference is better understood as one of scale, with the epitympanic sinuses of litopterns usually being inapparent externally (unlike smaller notoungulates such as mesotheriids and pachyrukhines; cf. Patterson, 1934; MacPhee, 2014).

\section{Cerebral Endocast}

To enhance accuracy in description, where useful we differentiate between actual brain structures (e.g., olfactory bulbs) as they would appear in vivo and the corresponding, but obviously nonisomorphic, portions of the endocast by adding a subscript " $c$ " to the structure's name (e.g., olfactory bulbs ${ }_{c}$ ). This distinction seems unnecessary to make for nonneural tissues such as blood vessels.

The only previously published endocast of any litoptern is that of Tetramerorhinus lucarius (= Proterotherium cavum) AMNH 9245, described by Simpson (1933) (fig. 23; appendix 1; taxonomy follows Soria, 2001, p. 42). Using newly acquired segmental data, we extend and reevaluate his notes on this specimen in light of complementary micro-CT evidence for IANIGLA-PV 29 (fig. 22).

ENDOCAST FLEXURE (EF): EF is defined as the angle subtended by a line running from the center of the olfactory bulb $_{c}$ to the center of the hypophysis $_{c}$, and another running from the latter point to the center of the foramen magnum (Macrini et al., 2006). In IANIGLA-PV 29 the EF value is $33^{\circ}$ (table 4 ). The width/length ratio of the endocast (excluding the medulla $a_{c}$ ) is 0.69 , and the height/width ratio is 1.13 (table 4).

ForEbRAIN REgION: In life, the most anterior structures of the endocast would have housed the olfactory bulbs and associated meninges (Macrini et al., 2007b). The bulbar portion of the endocast is small in IANIGLA-PV 29, contributing only $\sim 4 \%$ of the total volume (table 4 ). Bulbar contribution in Te. lucarius is also relatively small, although larger than previously thought (Simpson, 1933; fig. 23). In IANIGLA-PV 29 each bulb ${ }_{c}$ is subspherical (left side: width/length ratio, 1.45; height/length ratio 1.6), aligned with the main axis of the ipsilateral cerebral hemisphere $_{c}$, and widely separated from its partner at the midline. The circular fissure (= fissure endorhinalis of Simpson, 1933) separating the olfactory bulbs ${ }_{c}$ from the cerebral hemispheres $s_{c}$ is narrow and deep. The endocast lacks any indication of either accessory olfactory bulbs or olfac- 

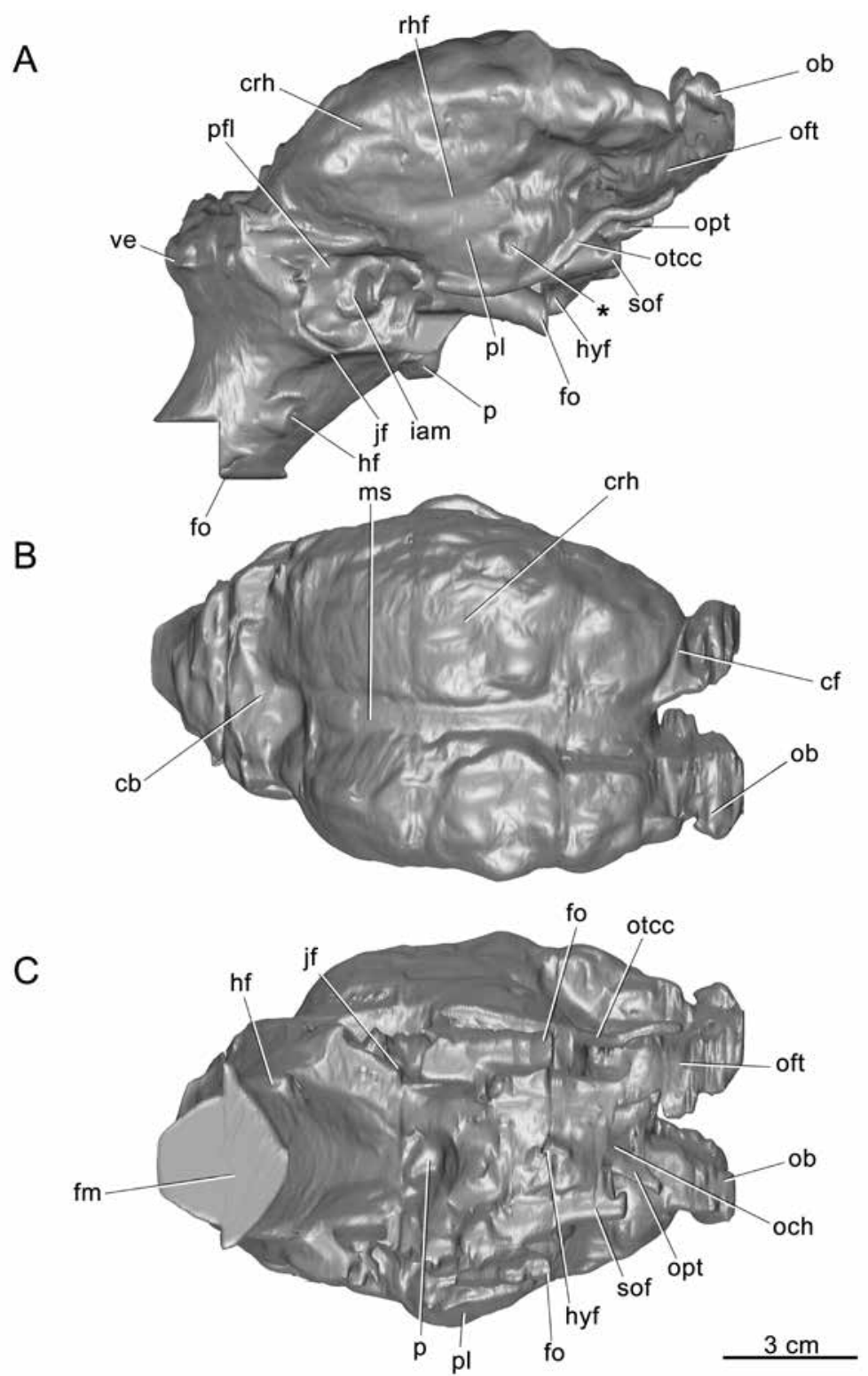

FIG. 22. Cerebral endocast of Huayqueriana cf. H. cristata IANIGLA-PV 29, in A, left lateral, B, dorsal, and C, ventral views. Abbreviations: cb, cast of cerebellum; cf, circular fissure; crh, cast of cerebral hemisphere; fm, spinal cord exiting foramen magnum; fo, mandibular division of trigeminal nerve $\left(\mathrm{CN}_{3}\right)$ transiting foramen ovale; hf, hypoglossal nerve (CN XII) transiting hypoglossal foramen; hyf, cast of hypophyseal fossa; iam, facial and vestibulocochlear nerves (CN VII and CN VIII) transiting internal acoustic meatus; jf, glossopharyngeal, vagus, and accessory nerves (CN IX, CN X, and CN XI) transiting jugular foramen; ms, median sulcus; ob, cast of olfactory bulb; och, optic chiasm; oft, olfactory tract; opt, optic tract (CN II); otcc, cast of orbitotemporal canal; p, pons; pfl, cast of paraflocculus; pl, cast of piriform lobe; rhf, rhinal fissure; sof, oculomotor, trochlear, ophthalmic and maxillary divisions of trigeminal, and abducens nerves (CN III, CN IV, $\left.\mathrm{CN} \mathrm{V}_{1,2}, \mathrm{CN} \mathrm{VI)} \mathrm{leading} \mathrm{to} \mathrm{sphenoorbital} \mathrm{fissure;} \mathrm{ve,} \mathrm{cast} \mathrm{of} \mathrm{vermis.} \mathrm{Asterisk}{ }^{*}\right)$ indicates depression on right lateral piriform lobe. 


\section{TABLE 4}

Digital endocast of Huayqueriana cf. H. cristata (IANIGLA-PV 29): Linear, angular, and volumetric measurements ${ }^{1}$

\author{
General \\ Endocast, volume ${ }^{2}$ \\ Endocast, flexure \\ Endocast, maximum length \\ Endocast, maximum width \\ Endocast, maximum height

\section{Bilateral structures} \\ Olfactory bulbs, $\mathrm{R}+\mathrm{L}$ volume \\ Olfactory bulbs, $\mathrm{R}+\mathrm{L}$ maximum width \\ Olfactory bulb, R anteroposterior length \\ Olfactory bulb, L anteroposterior length \\ Olfactory bulb, R maximum height \\ Olfactory bulb, L maximum height \\ Piriform lobes, $\mathrm{R}+\mathrm{L}$ volume \\ Cerebral hemispheres, $\mathrm{R}+\mathrm{L}$ volume \\ Cerebral hemisphere, $\mathrm{R}$ anteroposterior length \\ Cerebral hemisphere, $\mathrm{R}$ maximum width \\ Cerebral hemisphere, $\mathrm{R}$ maximum height \\ Cerebral hemisphere, $\mathrm{L}$ anteroposterior length \\ Cerebral hemisphere, L maximum width \\ Cerebral hemisphere, L maximum height
}

\section{Midline structures}

Hypophysis, volume

Hypophysis, anteroposterior length

Hypophysis, maximum width

Hypophysis, maximum height

Cerebellum, volume

\author{
$217290 \mathrm{~mm}^{3}$ \\ $33^{\circ}$ \\ $128 \mathrm{~mm}$ (oblique) / $119 \mathrm{~mm}$ (straight) \\ $82.3 \mathrm{~mm}$
}

$73 \mathrm{~mm}$

${ }^{1}$ As computed by the program 3DSlicer. ${ }^{2}$ Including olfactory bulbs but excluding medulla.

tory tracts projecting from the cortex (Macrini et al., 2007a, 2007b).

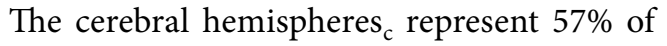
the total endocast volume (table 4). They are separated sagittally by a wide median sulcus. As already mentioned, the cerebral hemispheres are asymmetrical due to taphonomic deformation. The less affected right cerebral hemisphere ${ }_{c}$ is ovoid with a width/length ratio of 0.44 and a height/length ratio of 0.41 (table 4 ). The cortical surface is slightly gyrencephalic, with very shallow sulci or gyri. Conspicuously lacking are the well-marked and comparatively deep subparallel dorsal sulci seen on the endocast of Te. lucarius (Simpson, 1933; fig. 23B). In contrast, the rhinal fissure is well marked in both endocasts.

The piriform lobes ${ }_{\mathrm{c}}$ are laterally protruding, as in Te. lucarius (Simpson, 1933), and represent 
9\% of total endocast volume. In Simpson's (1933: fig. 3) illustration of Te. lucarius, there are two roughly circular depressions on each lobe $e_{c}$, one ventrolateral and the other ventral. The ventral depression is absent in the $3 \mathrm{D}$ model of $T e$. lucarius (fig. 23C), suggesting that this feature in Simpson's plaster version was a casting artifact. In Huayqueriana, there is only a single circular depression (?preservation artifact), situated on the right piriform lobe (fig. 22A) and similar in position to one on the new endocast of $T e$. lucarius (fig. 23A).

The hypophyseal region ${ }_{c}$, the space occupied in vivo by a portion of the pituitary gland (Macrini et al., 2007a), is represented by a small, shallow bulge, about $2.5 \%$ of total endocast volume. It is situated in the middle of the ventral floor, level with the anterior border of the piriform lobe $_{c}$ and slightly anterior to foramen ovale (fig. 15). The hypophysis $_{c}$ exhibits a medial keel, but this is probably an artifact of preservation due to damage affecting the floor of the hypophyseal fossa. There is no bony indication of the passage of the cerebral carotid artery, such as the sulcus sometimes found in mammals in close relation to the hypophyseal fossa (MacPhee, 1981).

HINDBRAIN REgION: The depression that separates the cerebrum ${ }_{c}$ and cerebellum ${ }_{c}$ is notably shallower in IANIGLA-PV 29 (fig. 22B) than in Te. lucarius (Simpson, 1933), which is consistent with a negligible or absent tentorium cerebelli (Macrini et al., 2007b). The volume of the cerebel$\operatorname{lum}_{\mathrm{c}}$ forms $22 \%$ of the total endocast, which is smaller than its contribution in Te. lucarius (Simpson, 1933). Interestingly, in IANIGLA-PV 29 the cerebellum $_{c}$ is narrower than any part of the cerebrum $_{\mathfrak{c}}$, whereas in dorsal view in Te. lucarius the former is as wide as the anterior portion of the cerebral hemisphere ${ }_{c}$ (Simpson, 1933).

In IANIGLA-PV 29 it is difficult to separate the impression for the vermis ${ }_{c}$ from that for the cerebellar hemispheres ${ }_{c}$, but the scan indicates that in dorsal view the vermis $s_{c}$ is roughly semispherical (fig. 17E). The surfaces of the cerebellar hemispheres $_{c}$ are smooth. Meninges, venous sinuses, and other structures (e.g., arachnoid granulations) affect endocast topography and consequently there is no direct correlation between the apparent degree of lissencephaly seen on hemisphere casts and actual, in vivo surfaces (Macrini et al., 2007a). The paraflocculus ${ }_{c}$, caudodorsal to the internal acoustic meatus on the lateral face of the cerebellar hemisphere ${ }_{\mathcal{c}}$, is less protruding than in Te. lucarius (Simpson, 1933). This correlates with the notable shallowness of the subarcuate fossa (see Petrosal).

The deepest endocast structure distinguishable in ventral view is the pons ${ }_{c}$, which projects from the ventral surface as an oval bulge. Posteriorly, the medulla oblongata ${ }_{\mathfrak{c}}$, circular in cross section, exits the skull via the foramen magnum.

Nerves AND vessels: Conspicuous nerves and blood vessels on the endocast of IANIGLAPV 29 may be briefly noted.

Anterior cranial fossa. The short optic chiasm ${ }_{\mathcal{c}}$, formed by the grooves that carried the right and left optic nerves ${ }_{c}$ (CN II), is clearly evident on the border between the anterior and middle cranial fossae, although somewhat deformed. The optic nerves $_{c}$ are relatively small in diameter and diverge at an angle of $\sim 88^{\circ}$ (fig. $22 \mathrm{C}$ ).

Middle cranial fossa. The sphenoorbital fissure (= anterior lacerate foramen of Simpson, 1933) is the aperture through which the oculomotor $(\mathrm{CN}$ III), trochlear (CN IV), ophthalmic $\left(\mathrm{CN} \mathrm{V}_{1}\right)$, maxillary $\left(\mathrm{CN} \mathrm{V}_{2}\right)$, and abducens ( $\mathrm{CN} \mathrm{VI}$ ) nerves typically leave the skull in eutherians (MacPhee, 1994). Because of their size and lateral disposition, the divisions of $\mathrm{CN} \mathrm{V}$ are usually the only cranial nerves that can be separately identified in the middle cranial fossa, and this is the case in IANIGLA-PV 29. The casts of the tracks of $\mathrm{CN} \mathrm{V}_{1}$ and $\mathrm{CN} \mathrm{V}_{2}$ converge at the sphenoorbital fissure, while that for the mandibular nerve $\left(\mathrm{CN} \mathrm{V}_{3}\right)$ passes through a distinct foramen ovale, as in other SANUs (Gabbert, 2004; Forasiepi et al., 2015b). As noted in the description of the skull, IANIGLA-PV 29 lacks a foramen rotundum providing an independent exit for the maxillary nerve $\left(\mathrm{CN} \mathrm{V}_{2}\right)$. Scott (1910: 18) suggested that, in Diadiaphorus and other litopterns, $\mathrm{CN} \mathrm{V}_{2}$ and $\mathrm{CN} \mathrm{V}_{3}$ exited together through 

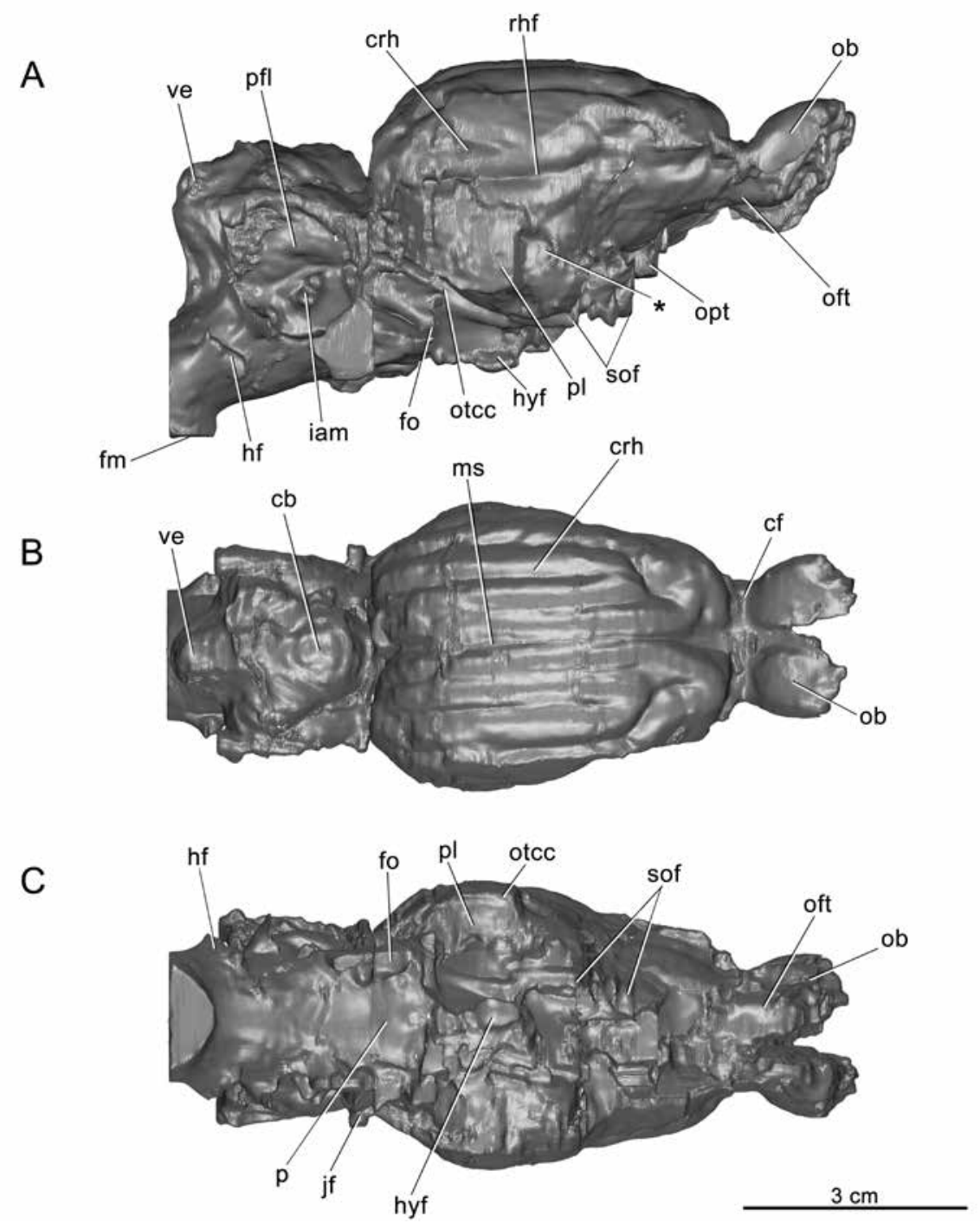

FIG. 23. Cerebral endocast of Tetramerorhinus lucarius (= Proterotherium cavum AMNH 9245) from Santa Cruz Formation, Santa Cruz, in A, left lateral, B, dorsal, and C, ventral views. Abbreviations: cb, cerebellum; cf, circular fissure; crh, cerebral hemisphere; fm, spinal cord exiting foramen magnum; fo, mandibular division of trigeminal nerve $\left(\mathrm{CN} \mathrm{V}_{3}\right)$ exiting foramen ovale; hf, hypoglossal nerve (CN XII) exiting hypoglossal foramen; hyf, hypophyseal fossa; iam, facial and vestibulocochlear nerves (CN VII and CN VIII) transiting internal acoustic meatus; jf, glossopharyngeal, vagus, and accessory nerves (CN IX, CN X, and CN XI) transiting jugular foramen; ms, median sulcus; ob, olfactory bulb; oft, olfactory tract; opt, optic tract (CN II); otcc, orbitotemporal canal; p, pons; pfl, paraflocculus; pl, piriform lobe; rhf, rhinal fissure; sof, oculomotor, trochlear, ophthalmic and maxillary divisions of trigeminal, and abducens nerves (CN III, CN VI, CN V $\mathrm{CN}$ VI) leading to sphenoorbital fissure; ve, vermis. Asterisk $\left(^{*}\right)$ indicates depression on right lateral piriform lobe. 
the foramen ovale, an unusual arrangement unknown in other eutherians. Simpson (1933: fig. 3) argued on the basis of his interpretation of the ventral surface of the endocast of Te. lucarius that $\mathrm{CN} \mathrm{V}_{2}$ passed instead through a separate foramen rotundum. The midcranial region of the specimen (AMNH 9245) on which Simpson's (1933) analysis was based shows signs of having been extensively repaired. In any case, neither the skull in its present condition nor the CT scan provides any evidence for an aperture conforming to a foramen rotundum on either side. In addition, the new endocast reconstruction of Te. lucarius demonstrates that the casts of $\mathrm{CN} \mathrm{V}_{1}$ and $\mathrm{CN} \mathrm{V}_{2}$ form a single bundle on the left side of the skull, while bone breakage and displacement on the right side gives an artificial impression of two separate bundles (fig. 23C). In short, $\mathrm{CN} \mathrm{V}_{2}$ in Te. lucarius must have departed the skull through the sphenoorbital fissure, as in other SANUs.

Foramen ovale, transmitting $\mathrm{CN} \mathrm{V}_{3}$, is large, circular in cross section, and obliquely oriented with respect to the floor of the brainstem (fig. 22A). In Te. lucarius (Simpson, 1933) the foramen is more vertically aligned than in IANIGLA-PV 29.

Posterior cranial fossa. The position of the internal acoustic meatus and morphological origins of the facial (CN VII) and vestibulocochlear (CN VIII) nerves are indicated by a small protuberance on the endocast at the level of the anterior portion of the cerebellum ${ }_{c}$ (fig. 22A). The track of the glossopharyngeal (CN IX), vagus $(\mathrm{CN} \mathrm{X})$, and accessory (CN XI) nerves toward the jugular foramen is suggested by a thick, anterolaterally directed feature on the floor of the brainstem. The cast of the canal transmitting the hypoglossal (CN XII) nerve through the single hypoglossal foramen is posterior and slightly medial to the previous structure.

Endocranial vasculature: Pneumatization of the skull complicates the identification of some vessels (figs. 10, 11, 17). In dorsal view (fig. $22 \mathrm{~B}$ ), the median sulcus would have supported a large superior sagittal sinus, draining blood from the dorsal portion of the brain into the transverse sinuses (e.g., Sisson and Grossman, 1975; Hiatt and Gartner, 2001). On the endocast of IANIGLA-PV 29 only a short section of the transverse sinus is preserved as an impression. The transverse sinus connects with (1) the foramina for rami temporales (fig. 17D), indicating vascular communication with the scalp, (2) the posttemporal canal (fig. 17A), transmitting the arteria diploëtica magna and a system of veins related to one or more venous sinuses (Wible, 1987, 2010; MacPhee, 2014), (3) the canal for the postglenoid vein (fig. 17C), via a short sigmoid vessel of very small diameter, and (4) the orbitotemporal canal.

Of these, the track of the orbitotemporal canal is of great interest because it differs from the routing usually seen. On the lateroventral aspect of the endocast, below the piriform lobe (fig. $_{\mathrm{c}}$. $22 \mathrm{~A}, \mathrm{C}$ ), there is a very distinct track that must be vascular because it runs along the periphery of the middle cranial fossa, low on the endocranial aspect of the squamosal. This corresponds to the orbitotemporal canal (= sinus canal), which transmits the ramus supraorbitalis (the anterior division of the ramus superior of the stapedial artery) and/or sinus vein (Wible, 1987, 2008). As confirmed by the CT scan, its pathway is partly intracranial and partly intramural, i.e., within the skull's sidewall (fig. 13D, E). On the specimen's left side, the cast of this vessel leaves the endocranial cavity via a small aperture within the orbit, at the level of, but posterior to, the optic foramen (fig. 14). A similar, but more dorsally located, structure is seen on the endocast of Te. lucarius AMNH 9245 (Simpson, 1933; fig. 23 A, B). In other regards the track is similar, as it runs forward almost horizontally at the level of the $\mathrm{CN} \mathrm{II}_{c}$. The diameter of the cast of the track is substantial in both specimens.

If our interpretation of conditions in IANIGLA-PV 29 is correct, the orbitotemporal canal in this specimen is unusual, for this feature normally creases the inner sidewall of the skull more dorsally, at the level of the upper portion of the squamosal or even the parietal (e.g., Wible, 1987, 
1993; Rougier et al., 1992). This places the vessel against the dorsal half of the piriform lobe (Orliac et al., 2012) or actually on the rhinal fissure (= lateral cerebral venous sinus of Simpson, 1933), for which it is sometimes considered a probable marker (e.g., Rowe, 1996; Silcox et al., 2011; Orihuela, 2014).

\section{UPPER DENTITION}

\section{ToOth Morphology}

The dental formula is $11-3, \mathrm{C}, \mathrm{P} 1-4, \mathrm{M} 1-3$ as in other macraucheniids (fig. 24; Bond, 1999). As already noted, the dentition of IANIGLA-PV 29 is exceptionally worn, with teeth in some cases having been worn down to their roots or actually avulsed during life. These factors limit morphological description.

I1-3 alveoli are preserved on each side of the premaxilla and follow the curve of the upper jaw as in H. cristata (MLP 41-IV-29-4), O. zeballosi MACN-PV 13671), and Pr. calchaquiorum (MACN-PV 5528). The I1s are separated by a median diastema that is wider than the alveoli that it borders. The alveolus for the canine is oval and separated from I3 and P1 by short diastemata, as in $H$. cristata (MLP 41-IV-29-4). The premolars and molars are heavily worn with predominant (and asymmetrical) wear on the left side. Enamel is preserved as a thin layer on the labial and distal surfaces of the better-preserved teeth and along the inner aspect of the fossettes. Of LP1 only its two roots remain, which are similar in size. The P2s are similarly worn, but the posterior root is larger. The RP3, worn down to the base of its crown, is more rectangular in shape in occlusal view than are the anterior premolars. RP4, also quadrangular in outline, exhibits two enamel fossettes on its lingual side, with the mesial the smallest. Both M1s were lost during life and their alveoli have been partially resorbed. The M2s are quadrangular in outline, with two lingual fossettes. The distal fossette is larger and more labially placed than the mesial fossette, similar to conditions in $\mathrm{Pa}$. denticulata (MACN-PV 4444). The labial styles are smooth and the paracone and metacone valleys are moderately pronounced. The M3s are trapezoidal in outline with the mesial portion wider than the distal as in other macraucheniids. There are three fossettes on the lingual side, in mesial to distal order, with a smaller fossette in a central position (latter only preserved on LM3).

\section{Tоотн Histology}

The dental histology of litopterns has been discussed for certain Paleogene taxa in relation to enamel microstructure (Line and Bergqvist, 2005). In IANIGLA-PV 29, the dental tissues are well preserved and clearly identifiable on the sectioned M2 (fig. 25). The coronal section, cut at the level of the interroot pad, shows a typical conformation with a succession of enamel (preserved only in a small area labially), dentine, and cementum layers in that order from the occlusal surface to the root (fig. 25A). The distal root transverse section also shows a classical conformation for a senescent non-euhypsodont mammal, showing a nearly obliterated pulp cavity. Covering the root externally, the cementum layer is thin over most of the coronal section, and shows rest lines. However, this layer is notably thickened in the mesial portion of the section, just dorsal to the interroot pad, closer to the crown of the tooth. The existence of this thickened area facilitated the counting and correlation of rest lines in both sections; fig. 25B, D). Growth zones (i.e., between the rest lines) have similar thicknesses, ca. $0.2 \mathrm{~mm}$. Although less clear, the transverse root section also presents a similar number of rest lines. The use of cementum rest lines in age estimation is discussed separately (see Longevity).

\section{DISCUSSION}

\section{Systematics}

TAxonomy: The hypodigm of Huayqueriana presently consists of four specimens. The first is the holotype, MACN-PV 8463 (fig. 2), collected in the Huayquerías de Biluco (De Carles, 1911), 

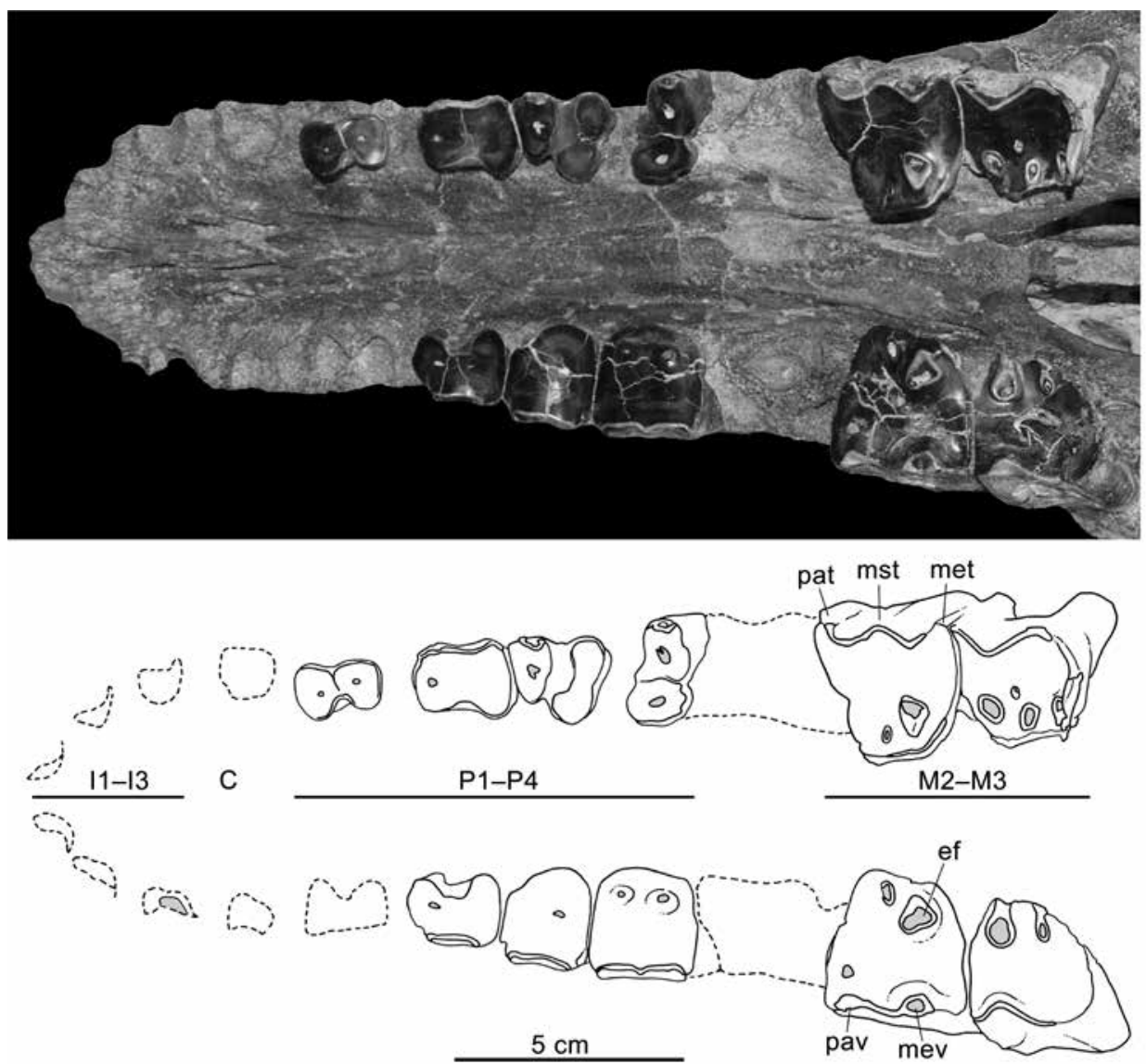

FIG. 24. Palate of Huayqueriana cf. H. cristata IANIGLA-PV 29, with detail of dentition in occlusal view. Abbreviations: C, canine (alveolus); ef, enamel fossette; I, incisor (alveolus); M, molar; met, metastyle; mev, metacone valley; mst, mesostyle; $\mathbf{P}$, premolar; pat, parastyle; pav, paracone valley.

south of Huayquerías del Este, and believed to have come from the HF (Soria, 1986; Pascual and de la Fuente, 1993). However, as noted earlier (see Geographic and Geological Contexts), the interpretation of the stratigraphic position of the holotype is currently uncertain.

Huayqueriana cristata was originally placed within the genus Promacrauchenia (Rovereto, 1914). Kraglievich (1934) later erected the subgenus Huayqueriana, which Soria (1986) subsequently elevated to the status of full genus. Soria also considered Macrauchenidia latidens (MLP 37-III-7-2), from the Epecuén Formation (Buenos Aires), to be a synonym of $H$. cristata (Soria, 1986). In the same study, Soria (1986) referred
MLP 41-IV-29-4 to H. cristata (figs. 5A, 6A, 7A). The fourth and last specimen to be attributed to Huayqueriana is IANIGLA-PV 29, which we formally designate as Huayqueriana cf. $H$. cristata.

IANIGLA-PV 29 shares some nonexclusive features with the holotype of $H$. cristata (e.g., similar size as recorded in table 2 , rostral border of the orbit almost level with the distal border of $\mathrm{M} 3$, and convergence of maxillary bones at the level of the P3/P4 embrasure). MACN-PV 8463 (holotype), MLP 41-IV-29-4, and IANIGLA-PV 29 all share possession of a flat snout as seen in lateral view and notably protuberant orbits as seen in dorsal view. IANIGLA-PV 29 also shares with MLP 41-IV-29-4 the round outline of the 

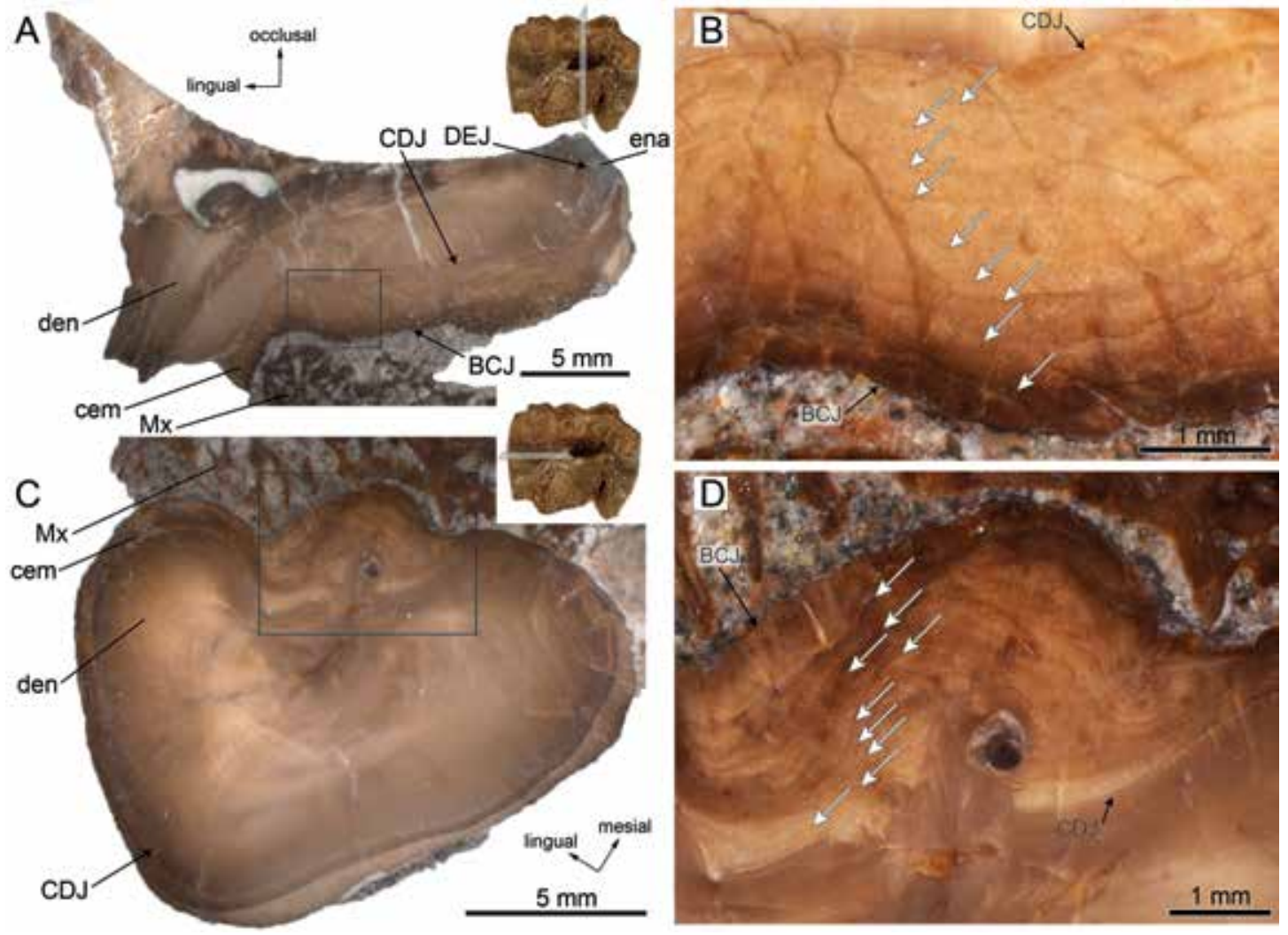

FIG 25. Dental histology of left M2 of Huayqueriana cf. H. cristata IANIGLA-PV 29. Coronal section: A, whole surface and B, detail of cementum layer (rectangle in A). Para-occlusal section: C, whole surface and $\mathbf{D}$, detail of cementum layer (rectangle in $\mathrm{C}$ ). Cementum rest lines indicated by white arrows. Abbreviations: BCJ, bone-cementum junction; CDJ, cementum-dentine junction; cem, cementum; DEJ, dentine-enamel junction; den, dentine; ena, enamel; Mx, maxilla.

premaxillary area in palatal view and small diastemata between I3-C and C-P1. None of these features is identifiable in the holotype.

By contrast, both IANIGLA-PV 29 and MLP 41-IV-29-4 lack the sagittal crest evident in the holotype. To explain this difference, Soria (1986) suggested that MLP 41-IV-29-4 represented an earlier ontogenetic stage than the holotype, arguing that the crest grew with positive allometry during ontogeny.

The sagittal crest provides extra attachment for the temporalis muscle and its production is a direct consequence of the development of this muscle (Holbrook, 2002). In many mammals the growing muscular mass modifies the surface of the vault such that the temporal lines migrate dorsally and medially to eventually coalesce as the sagittal crest (e.g., Tapirus pinchaque; Holbrook, 2002). However, as already noted, IANIGLA-PV 29 is in fact a senile specimen, in which the temporal lines converged but never met.

Sagittal crests are constantly present in some large- and medium-sized herbivores (e.g., Tapirus terrestris; Holbrook, 2002), while in others it is a matter of individual variation (e.g., Tayassu pecari, Tragulus javanicus; AMF personal obs.). The crest on the holotype of $H$. cristata is short and restricted to the posterior vault; IANIGLAPV 29 is actually very similar, in that the temporal lines are in a nearly identical topographic 
position, despite their failure to unite. This suggests that sagittal crest presence in Huayqueriana may have varied individually. Sagittal cresting has been best studied in primates (e.g., in New World monkeys, Hershkovitz, 1977). According to notes collected by Napier and Napier (1967) and Osman Hill (1966), cresting is possibly related to age or sex (or both) in chimpanzee, Pan troglodytes, and various species of the mona monkey, Cercopithecus mona, with older, larger individuals sometimes displaying short crests while in others crests are absent or negligible. Whether such variation occurred in any litoptern is unknown, but it should be considered as a possibility when assessing its value for making taxonomic distinctions.

In conclusion, it is evident that resolving the alpha taxonomy of macraucheniines will be a major task, due to the number of named forms and their rather uniform skull and dental morphology (e.g., Lydekker, 1894; Soria, 1981). Several macraucheniine species have been erected on isolated (and thus potentially noncomparable) postcranial elements (e.g., Ma. ensenadensis, Pr. kraglievichi, Pr. chapalmalense, Pr. (Pseudomacrauchenia) yepesi, S. rusconii; Kraglievich, 1930; Parodi, 1931). Size has often been the most important, if not the only, criterion for distinguishing species (e.g., Ameghino, 1883b; Scott, 1910; Parodi, 1931, Soria, 1981, 1986; Cartelle and Lessa, 1988), which further complicates the picture because the degree of within-group variability is essentially unknown or poorly investigated (see Schmidt, 2013).

However, the significant number of features shared by IANIGLA-PV 29 and the holotype of Huayqueriana MACN-PV 8463 and referred specimen MLP 41-IV-29-4 indicates that its referral to this genus is correct. At the same time, there are also some differences that may or may not be due to intraspecific variation. This point can be resolved only by the discovery of additional specimens and further taxonomic studies.

Phylogenetic AnAlysis: A parsimony analysis was performed based on 19 taxa scored for 34 morphological cranial and dental characters, using a modified version of the matrix of Schmidt and Ferrero (2014) and eight additional characters (appendix 2). Six characters on which a logical sequence could be imposed to their states were treated as additive (chars. 1, 4, 25-27, 29).

The taxon set includes seven outgroup members: two Adiantidae, including Proadiantus excavatus and Tricoelodus spp.; and five cramaucheniine macraucheniids, including Cramauchenia normalis, Coniopternium spp., Polymorphis lechei, Pternoconius spp., and Theosodon spp. The composition of the outgroup varied, depending on the analysis (see below). The ingroup includes 12 macraucheniine macraucheniids: Cullinia levis, Huayqueriana cristata, Oxyodontherium zeballosi, Paranauchenia hystata, Paranauchenia denticulata, Promacrauchenia antiquua, Promacrauchenia calchaquiorum, Scalabrinitherium bravardi, Xenorhinotherium bahiense, Macrauchenia patachonica, Macrauchenopsis ensenadensis, and Windhausenia delacroixi, plus IANIGLA-PV 29 here identified as Huayqueriana cf. H. cristata.

The data matrix (appendix 2) was analyzed using TNT 1.1 (Goloboff et al., 2008) under maximum parsimony. The analysis included a heuristic search of Wagner trees with 1000 random addition sequences, followed by TBR and retention of 10 trees per round.

The first analysis (all taxa included, Proadiantus excavatus used as "strict outgroup" to give plesiomorphic states of characters) yielded 27 most parsimonious topologies (length, 70; CI, 0.643; RI, 0.786; fig. 26A). Macraucheniinae is supported by 11 characters. The standard bootstrap GC values in our trees are low for all groups (macraucheniine GC value, 39; fig. 26A), and this analysis failed to satisfactory resolve the phylogenetic position of macraucheniines. The consensus tree displays a polytomy for macraucheniines, with only $\mathrm{Pa}$. denticulata and $\mathrm{Pa}$. hystata recovered as sister taxa and the Late Pliocene/Pleistocene species $W$. delacroixi, $X$. bahiense, Ma. ensenadensis, and M. patachonica forming a monophyletic group. 
A second analysis was performed using only the taxa for which $50 \%$ or more of the characters could be scored, and with Polymorphis lechei, Cramauchenia normalis, and Theosodon spp. as outgroup. Polymorphis lechei was used as the "strict outgroup" (fig. 26B). Outgroup taxa incompletely coded were pruned. The analysis provided three trees (length, 61; CI, 0.738; RI, 0.863). Even so, $H$. cristata and Huayqueriana cf. $H$. cristata failed to form a monophyletic group, as did the species of Promacrauchenia. Standard bootstrap GC values improved for all nodes (macraucheniine GC value, 84; fig. 26B). Forcing the monophyly of Huayqueriana and Promacrauchenia species required only one additional step.

A third analysis, limited to taxa with $75 \%$ or more characters scorable, with only Cramauchenia normalis and Theosodon spp. as the outgroup (the former used as "strict outgroup"), resulted in three trees (length, 55; CI, 0.818; RI, 0.915; fig. 26C). Oxyodontherium zeballosi and $S$. bravardi placed respectively as successive sister taxa to the remaining macraucheniines, but the standard bootstrap GC values are very low at their nodes (fig. 26C). This arrangement resembles somewhat the result obtained by Schmidt and Ferrero (2014), with Scalabrinitherium as the sister taxon of Oxyodontherium and remaining macraucheniines. In contrast, Soria (1986) interpreted skull features of Huayqueriana as representing the primitive morphology for Macraucheniinae. Our results are inconclusive (fig. 26A, B); however, in the third, most restricted, analysis (fig. 26C), Huayqueriana was found to be nested within macraucheniines, closest to Macrauchenia and related Plio-Pleistocene taxa. Overall, lack of resolution is probably due either to the choice of characters, or to inherent problems with the group's alpha taxonomy (e.g., Soria, 1981) that may in turn be largely driven by unappreciated intraspecific variation.

ChARACTER ANALYSIS AND TAXON DEFINITION: Macraucheniinae is a monophyletic group of medium- to large-sized macraucheniids (fig. 26), characterized by the following combination of features (diagnosis modified from Soria, 1981).

Skull: Long rostrum and maxilla posteriorly and dorsally projecting; reduced nasals (char. $1: 2$ ); nasal aperture on top of skull, level with orbit (char. 2:1); palate narrowing at level of P2 or P3 (char. 3:1); postorbital bar with small gap (char. 4:1) or complete; infraorbital foramen anterior to M3 (char. 26:2); contact of premaxilla and maxilla in dorsal view (char. 27:2), with these bones housing a diverticulum (meatus nasi ventralis) not on the direct passageway for air flowing through the nasopharynx; sagittal crest absent or variably present (char. 30:1).

Dentition: Mesodont and selenodont postcanine teeth with labially projecting parastyle on P3-P4 (char. 10:0); deep concavity between labial styles (parastyle, mesostyle, and metastyle) on M1-M3 (char. 11:1); precingulum on M1-M2, slightly lingual or at same level as posterolingual cingulum (char. 14:1); c-p2 obliquely implanted (char. 22:0) and imbricated.

Postcranium: Fused radius/ulna; partly fused tibia and fibula; and tridactyl autopodium.

Most of the character transformations identified on the cranium of macraucheniines are related in one way or another to the massive dorsocaudal retraction and enlargement of the nasal aperture. These transformations, which can be traced in successive taxa over time from Early through Late Miocene (Ameghino, 1893; Scott, 1910, 1937; Rusconi 1957; Soria, 1986), yielded the distinctive "telescoped" skull of later macraucheniines in which the facial bones became caudally displaced relative to the braincase. Among earlier taxa, the stem macraucheniine Theosodon (fig. 26) is especially noteworthy for the role it has played in efforts to interpret the highly derived architecture of later forms (Ameghino, 1893; Scott, 1910, 1937; Rusconi 1957; Soria, 1986).

Nasal aperture retraction has invited considerable comment over the years (e.g., Burmeister, 1864, Wall, 1980; Milewski and Dierenfeld, 2013), leading to the hypothesis that it was connected to a mobile proboscis like that of an elephant, a hydrostat like that of a tapir, or, perhaps most inventively, an oper- 
A

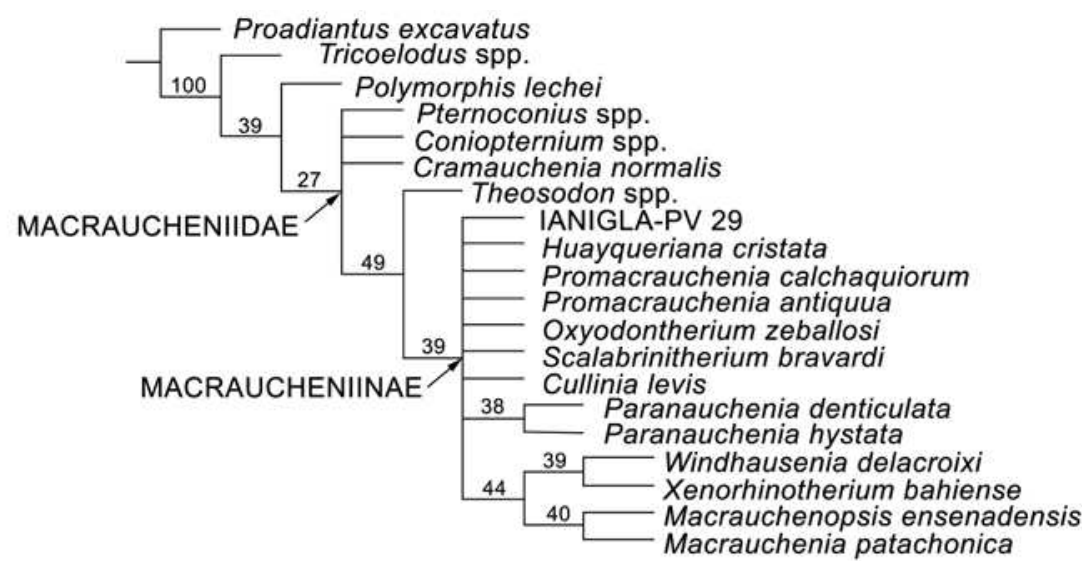

B

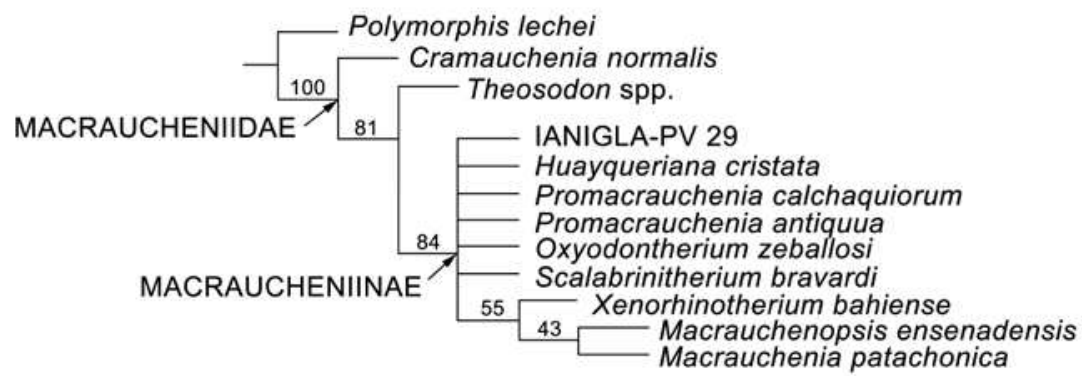

C

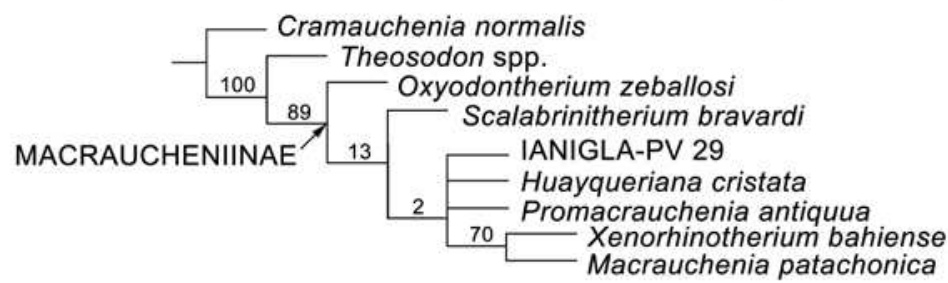

FIG. 26. A, Strict consensus of 27 most parsimonious trees (length, 70; CI, 0.643; RI, 0.786); B, strict consensus of 3 most parsimonious trees (length, 61; CI, 0.738; RI, 0.863), restricted to taxa with $50 \%$ or more of total characters scorable; $\mathbf{C}$, strict consensus of 3 most parsimonious trees (length, 55; CI, 0.818; RI, 0.915), restricted to taxa with $75 \%$ or more characters scorable. Bootstrap GC values are given at nodes.

culum (Sefve, 1925; Scott, 1937; Rusconi, 1957; Soria, 1981; Bond, 1999). Whatever the nature of associated soft tissues, the progressive reorientation of the air passage in macraucheniines from a position coplanar with the palate to roughly at a right angle to the latter is apparently unique among terrestrial mammals. No other taxa, including elephants (e.g., Todd, 2010), display a comparable level of modification. The only real approach in a morphological sense occurs in odontocetes (e.g., Tursiops; Racicot and Colbert, 2002), a morphofunctional convergence that defies any obvious explanation.

\section{Paleobiology of Huayqueriana}

Head Posture: Following De Beer (1947), the possible life position of the head of Huayqueriana IANIGLA-PV 29 was explored by digitally projecting the $3 \mathrm{D}$ model of the inner ear onto the skull, with the plane of the LSC parallel to the horizon (fig. 27). This orientation is biologically meaningful because the LSC is usually horizontal to the substrate when the animal's head is in the position of normal visual alertness (De Beer, 1947; Ekdale, 2013). At rest 


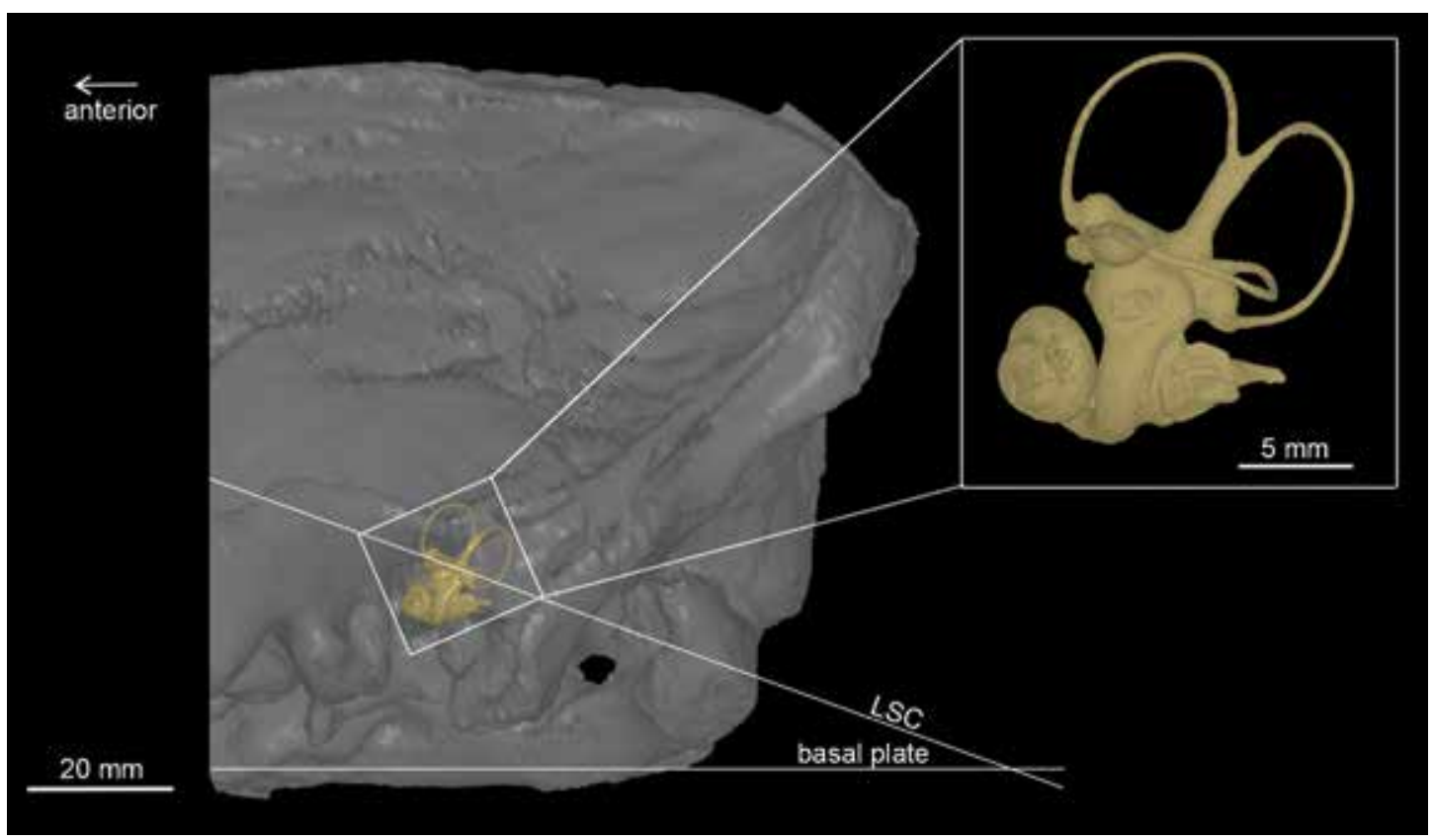

FIG. 27. 3D model of skull and inner ear of Huayqueriana cf. H. cristata IANIGLA-PV 29, showing angular relationship between plane of lateral semicircular canal (LSC) and that of skull floor (basal plane), following De Beer (1947).

or during dynamic activities (i.e., locomotion, grooming, feeding) the LSC is displaced relative to the horizon (Hullar, 2006). When the LSC is horizontal, the ASC and PSC are vertical and would experience the least stimulation when the head is rotated. This disposition allows the organ of balance to function at maximum efficiency (De Beer 1947).

In IANIGLA-PV 29, the angle subtended by the plane of the LSC and the plane of the base of the skull is about $26^{\circ}$, which is a value similar to that of the horse (De Beer, 1947) (fig. 28). Such a head posture in Huayqueriana might have enabled partial binocular vision, as occurs in horses and certain other ungulates (Miller, 1975; Marcus and Sarmiento, 1996). Additionally, among xenarthrans, a strongly inclined LSC was found in armadillos, and regarded as consistent with their "nose down" head position (G. Billet., personal commun., 2016).

BODY SIZE: Our efforts to predict the body mass of IANIGLA-PV 29 using several different approaches are summarized in table 5. Mean body mass predicted by the equations published by Janis (1990) imply that the mass of Huayqueriana cf. $H$. cristata approached $400 \mathrm{~kg}$. This is a significantly larger body mass than known empirical ranges for allometrically comparable panperissodactyls (Welker et al., 2015) such as extant Tapirus (T. indicus, 250-375 kg; T. terrestris, 77-300 kg) and wild Equus caballus (200$300 \mathrm{~kg}$ ) (Nowak and Paradiso, 1983; Silva and Downing, 1995; Clauss et al., 2003). It is also noteworthy that the range of Janis' estimators is considerable (154 to $721 \mathrm{~kg}$ ), with a percent prediction error above $25 \%$.

A second approach, utilizing algorithm 4.1 of Mendoza et al. (2006), produces a considerably lower estimate of $\sim 230 \mathrm{~kg}$ for IANIGLA-PV 29 (table 5). The percent prediction error was also lower, at $16 \%$. A third approach, using the equations published by Cassini et al. (2012b), yielded the lowest percent prediction error of all $(\sim 6 \%)$. Their CR4 statistic utilizes the centroid size of a 


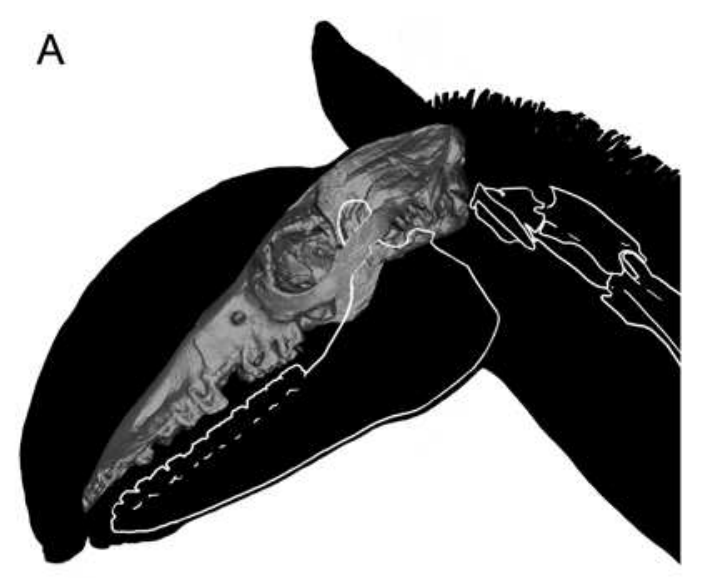

B

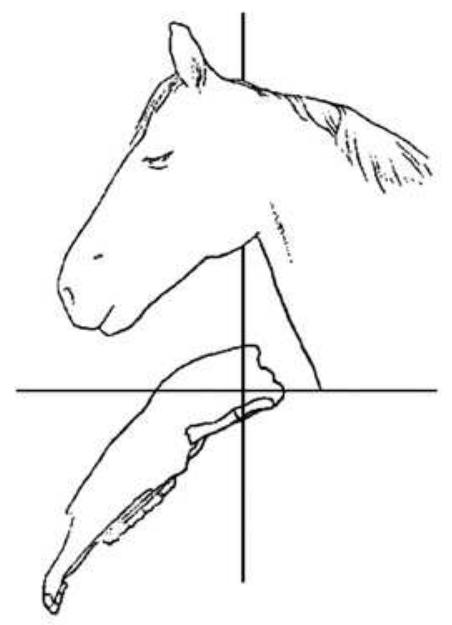

FIG. 28. Reconstruction of orientation of head of $\mathbf{A}$, Huayqueriana cf. H. cristata IANIGLA-PV 29 and B, horse (following De Beer, 1947), as they might appear in state of normal visual alertness.

configuration of 36 3D cranial landmarks to predict body mass, which in this case produced a value of $250 \mathrm{~kg}$.

Interpretation of body mass estimates based on different body parts is often difficult because they produce inherently incompatible results. Thus in the case of Janis' (1990) equations, considerable disparity exists between results based on dental vs. cranial material of IANIGLA-PV 29 (table 5), with dentally based estimators yielding substantially larger body sizes. As more comprehensive studies show (Fortelius, 1990; Millien and Bovy, 2010), body mass estimations based on cranial and postcranial measurements are preferable to ones based on dental measurements.

To assess apparent overestimation in a quantitative manner, Cassini et al. (2012b) developed a quantile regression statistic (Qsup) that provides a theoretical maximum body mass for a given centroid size (CS) based on (in this instance) extant ungulates. In the case of IANIGLA-PV 29, there is no extant ungulate with a CS similar to that of the fossil whose mean body mass surpasses $419 \mathrm{~kg}$ (CS maximum, for Bos taurus), and in light of this we reject results produced by all three of Janis' dental equations (SUMA, SUMW, SUML). Fariña et al. (1998) reached a similar conclusion when employing Janis' dental regression equations to predict the body size of Macrauchenia patachonica (e.g., SUML $=1500 \mathrm{~kg}$ vs. their mean estimate of 988 $\mathrm{kg}$ based on 66 cranial and postcranial equations). This suggests that a body mass of $400 \mathrm{~kg}$ for Promacrauchenia, as estimated by Vizcaíno et al. (2012), probably also requires reassessment.

By contrast, the mean for Janis' nondental equations is $\sim 265 \mathrm{~kg}$, a value more consistent with results obtained using algorithm 4.1 of Mendoza et al. (2006) and the CR4 equation of Cassini et al. (2012b). In particular, a value of $250 \mathrm{~kg}$ for the body mass of Huayqueriana IANIGLA-PV 29, using the CR4 statistic of Cassini et al. (2012b), seems more realistic than much larger estimates, and is more in accord with body sizes seen in distantly related taxa such as extant Tapirus and Equus. These results suggest that a rough doubling of body size occurred in macraucheniines between the time of Santacrucian Theosodon ( 130 kg; Cassini et al., 2012a, 2012b) and Huayquerian Huayqueriana. Further insights into macraucheniine body size will require discovery of associated elements of Huayqueriana, particularly long bones.

LONGEVITY: Given the extremely advanced dental wear of IANIGLA-PV 29, it can be argued that the specimen was approaching its maximum longevity at the time of death. Counting cementum rest lines, which in principle are deposited 
TABLE 5

Body mass estimation of Huayqueriana cf. H. cristata

\begin{tabular}{|c|c|c|}
\hline Expressions & Prediction error (\%) & Body mass $(\mathrm{BM})$ in $\mathrm{kg}$ \\
\hline \multicolumn{3}{|l|}{ Janis $(1990)^{1}$ : } \\
\hline TSL & 30.5 & 339.27 \\
\hline $\mathrm{OCH}$ & 28.1 & 154.39 \\
\hline PSL & 33.4 & 261.67 \\
\hline BCL & 51.8 & 306.11 \\
\hline SUML & 34.7 & 407.52 \\
\hline SUMW & 38.9 & 721.18 \\
\hline SUMA & 32.7 & 562.55 \\
\hline Average & & 393.24 \\
\hline \multicolumn{3}{|c|}{ Christiansen and Harris $(2005)^{2}$ : } \\
\hline Weighted mean & & $397.35^{3}$ \\
\hline \multicolumn{3}{|c|}{ Mendoza et al. $(2006)^{3}$ : } \\
\hline Algorithm 4.1 & $13.5-17.5$ & 228.83 \\
\hline \multicolumn{3}{|c|}{ Cassini et al. (2012b) ${ }^{4}$ : } \\
\hline CR4 & & 250.6593 \\
\hline Qsup & & 419.3906 \\
\hline
\end{tabular}

${ }^{1}$ Equations of Janis (1990) after Cassini et al. $(2012 \mathrm{a}): \log 10(\mathrm{BM})=2.975^{*} \log 10(\mathrm{TSL})-2.344 ; \log 10(\mathrm{BM})=2.873^{\star} \log 10$ $(\mathrm{OCH})-0.457 ; \log 10(\mathrm{BM})=2.758^{\star} \log 10(\mathrm{PSL})-0.973 ; \log 10(\mathrm{BM})=3.137^{\star} \log 10(\mathrm{BCL})-1.062 ; \log 10(\mathrm{BM})=$ $3.184^{*} \log 10(\mathrm{SUML})+1.091 ; \log 10(\mathrm{BM})=3.004^{*} \log 10(\mathrm{SUMW})+1.469 ; \log 10(\mathrm{BM})=1.568^{*} \log 10(\mathrm{SUMA})+1.277 ;$ in which BCL, basicranial length; BM, body mass in kg, OCH, occipital height; PSL, posterior skull length; SUMA, second upper molar area; SUML, second upper molar length; SUMW, second upper molar width; TSL, total skull length. Measurements in table 2 .

${ }^{2}$ Equation from Christiansen and Harris (2005) for multiple estimates ( $n$ ). The final body mass (M) average is:

$\mathrm{W}_{\mathrm{M}}=\sum_{\mathrm{M}_{\mathrm{i}}}^{1}\left(\left(\mathrm{M}_{\mathrm{i}} / \% \mathrm{PE} \mathrm{E}_{\mathrm{i}}\right)^{*} \sum_{\mathrm{M}_{\mathrm{i}}}^{1} \% \mathrm{PE}\right)^{*} n^{-2}$

where $\mathrm{M}$ is the body mass computed by the regression equations and $n$ is the sample size.

\footnotetext{
${ }^{3}$ Equation of Mendoza et al. (2006) after Cassini et al. (2012a) $:$ Ln Algorithm 4.1 $=0.736^{\star} \operatorname{Ln}(\mathrm{SUML})+0.606^{\star} \operatorname{Ln}(\mathrm{SUMW})+$ $0.530^{\star} \operatorname{Ln}(\mathrm{MZW})+0.621^{\star} \operatorname{Ln}(\mathrm{PAW})+0.741^{\star} \operatorname{Ln}(\mathrm{SC})-0.157^{\star} \operatorname{Ln}(\mathrm{SD})+0.603$; in which MZW, muzzle width; PAW, palatal width; $\mathrm{SC}=$ PSL, posterior skull length; SD, depth of the face under the orbit; SUML, second upper molar length; SUMW, second upper molar width. Measurements in table 2.

${ }^{4}$ Centroid size follows Cassini et al. (2012b) : CR4: $\log 10(\mathrm{BM})=3.165^{\star} \log 10(\mathrm{CS})-6.701 ;$ Qsup: $\log 10(\mathrm{BM})=3.321^{\star} \log 10$ (CS) -6.926 .
} 


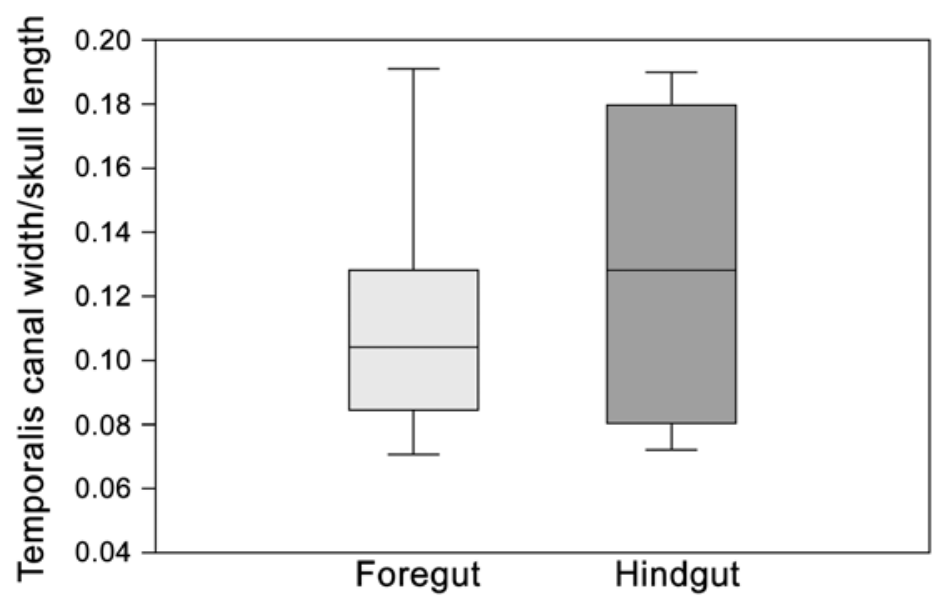

FIG. 29. Box plot depicting ratio of temporalis canal width to skull length in fore- and hindgut fermenters (pooled as such). Foregut and hindgut fermenters are not significantly different, whether data were analyzed all together as here or pooled by family (see fig. 30 and appendix 3 ).

annually, is often considered the most reliable method of calculating longevity, especially if the animal lives in a temperate climate (Klevezal, 1996) in which there is a distinct low-growth season, usually winter (e.g., Chritz et al., 2009). Age assessment is less precise for mammals living in tropical areas, which lack extreme seasonality. Lines may be indistinct, or two lines may be deposited during a single year (Klevezal, 1996). But given the fact that the Huayquerias fossil site is in a temperate region and that seasonality in the area was probably already established by the Late Miocene, we consider that these lines represent annual depositions. Nine cementum lines can be counted on the sectioned M2 of IANIGLA-PV 29. However, converting that to a plausible age requires correction. Because the last growth layer (external to the last rest line, where the periodontal ligament attached the tooth to the maxilla) is almost as thick as each preceding layer (fig. 25), it may be concluded that the animal died at the end of a year. Based on the data of Klevezal (1996) for the M1 and M2 of ungulates, a correction of 0 to 1 year must be added to the cementum count. Therefore, we suggest that IANIGLA-PV 29 died at an age of almost 10 or 11 years.
Longevity is known to be positively correlated with body size in mammals (Schmidt-Nielsen, 1984). We compared the estimated age of IANIGLA-PV 29 to the longevity of wild extant ungulates approximating a body mass of $250 \mathrm{~kg}$ (longevity data from AnAge database, Tacutu et al., 2013; body mass ranges from Nowak and Paradisio, 1983). Longevity is notably greater in the latter. Examples are: $~ 15$ years for the topi, Damaliscus lunatus; 24 years for the muskox, Ovibos moschatus; and 22 years, or possibly more, for the elk, Cervus canadensis, or moose, Alces alces. By contrast, ungulates with a longevity in the wild of roughly 10-12 years are conspicuously smaller, with a mean body mass below $100 \mathrm{~kg}$ (e.g., the east Caucasian tur, Capra cylindricornis, $50 \mathrm{~kg}$; the markhor, Capra falconeri, $41 \mathrm{~kg}$; the goitered gazelle, Gazella subgutturosa, $49 \mathrm{~kg}$; the Nile lechwe, Kobus megaceros, $90 \mathrm{~kg}$; the gerenuk, Litocranius walleri, $44 \mathrm{~kg}$; the common rhebok, Pelea capreolus, $25 \mathrm{~kg}$; the blue duiker, Philantomba monticola, $6 \mathrm{~kg}$; the mountain reedbuck, Redunca fulvorufula, $30 \mathrm{~kg}$; the brocket, Mazama, 17-33 $\mathrm{kg}$; and the pygmy hog, Sus salvanius, $8 \mathrm{~kg}$ ). The clear conclusion is that, compared to the longevity of modern wild ungulates of a size similar to Huayqueriana, the latter had a much shorter lifes- 
pan. Note that the magnitude of this conclusion would only increase if larger size estimates were used for Huayqueriana.

To provide additional context we also sectioned the M1 of an adult Theosodon garrettorum (PIMUZ A/V 4662). Its wear stage is very advanced (styles are completely worn on M1, but on M2-M3 the external outlines are still evident). The specimen exhibited 6 to 7 cementum lines and a thin last growth layer, yielding a likely age of 6-8 years, which is much lower than expected for its body size (ca. $140 \mathrm{~kg}$; Cassini et al., 2012a). Indeed, artiodactyls of similar size live up to $\sim 20$ years in the wild (e.g., fallow deer, Dama dama, 25 years; Pere David's deer, Elaphurus davidianus, 18 years). Our finding opens the question of the influence of environment and food items on longevity reduction in mesodont herbivores during the late Neogene. Unlike notoungulates and many other clades of South American placentals, litopterns failed to develop euhypsodont dentitions as an outcome of adaptation to ecosystem change (Madden, 2015).

Digestive Physiology: Herbivores utilize different strategies to efficiently digest celluloserich vegetation. The broadest partition is between taxa that ferment plant material in the foregut (stomach and/or specialized portions of the small intestine; e.g., ruminant artiodactyls, hippos, colobine monkeys, muroid rodents, sloths, kangaroos, koalas) as opposed to those that utilize the hindgut (caecum and/or colon; e.g., perissodactyls, proboscideans, hyraxes, ateline monkeys, caviomorph rodents, rabbits, wombats) (Clauss et al., 2003; Fletcher et al., 2010). In general, extant hindgut fermenters have a greater capacity for food intake than foregut fermenters of similar size and diet, and also chew their food more on initial ingestion (Clauss et al., 2003; Fletcher et al., 2010). The most specialized foregut fermenters, among which are ruminant artiodactyls, rely on regurgitation, rechewing, and remixing of digestive fluids to ensure maximum extraction of nutrient value from food. In contrast, after initial intake and chewing, hindgut fermenters rely exclusively on chemical reac- tions in the caecum or colon for nutrient extraction-an ultimately less efficient process.

Although there are marked differences between foregut and hindgut fermenters in digestive physiology, these differences are not reflected osteologically in any obvious way, which makes predictions difficult or impossible for extinct taxa. In principle, differentiation might be expected in the relative occlusal surface area of the cheek teeth For example, occlusal area seems to be larger in hindgut fermenters of similar size and diet, who also chew food more vigorously in the first stages of digestion than foregut fermenters do (Vizcaíno et al., 2006; Cassini et al., 2012a). Differences in jaw mechanics may also be indicative, at least in theory, as jaw size and musculature should be greater in hindgut fermenters of similar body size and diet than foregut fermenter (e.g., Fletcher et al., 2010).

Based on a study of the occlusal surface areas of cheek teeth, Cassini et al. (2012a) demonstrated that all Early Miocene litopterns may have had a gut physiology comparable to hindgut fermenters. In contrast, Madden (2015) concluded that macraucheniids appear to have possessed an inferred masticatory muscle mass more like that of foregut fermenting ruminants than hindgut digesters. He assessed masticatory muscle mass in 24 specimens (representing 11 taxa of various placental groups) on the basis of two osteological measurements, skull length (SL) and width of temporalis canal or temporal fossa (TS). On his analysis the two fermentation styles were found to form two distinct groups (Madden, 2015).

In order to test Madden's hypothesis statistically, we measured SL and TS in 43 foregut and hindgut fermenters (distributed across 11 taxa; appendix 3). In our analysis, foregut and hindgut fermenters did not form distinct groups (fig. 29). As the data do not follow a normal distribution as judged by the Shapiro-Wilk and AndersonDarling tests ( $p$-value $<0.01$ for the foregut fermenter group), either a nonparametric test or a data transformation is needed to compare the two groups. Using the nonparametric MannWhitney $U$ test, we found that there is no signifi- 


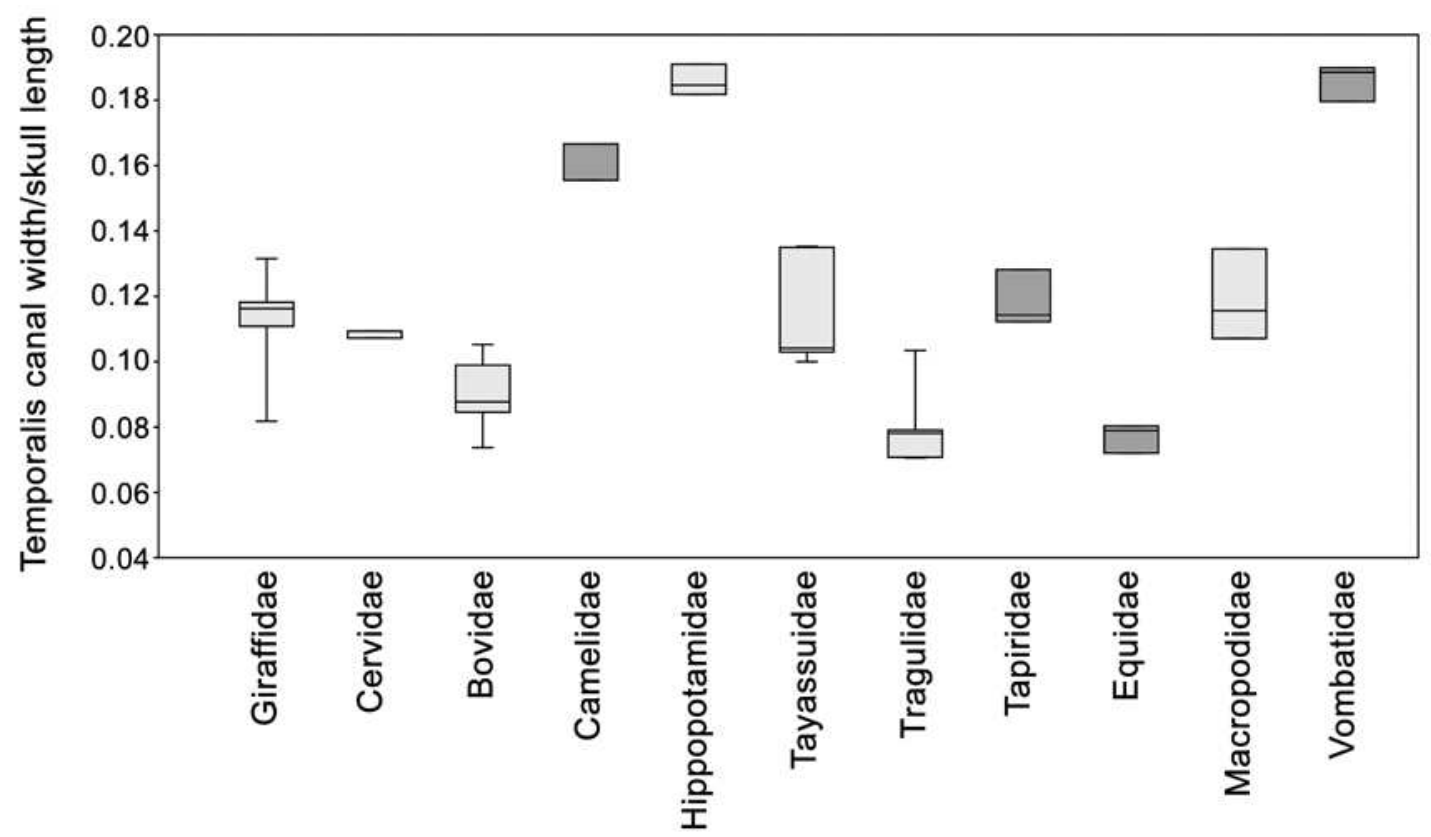

FIG. 30. Box plot depicting ratio of temporalis canal width to skull length, with data pooled by family (appendix 3).

cant difference between the two groups (p-value $>0.14$ ). Similarly, after log-transforming the data and checking for both normality of the distribution (Shapiro-Wilk and Anderson-Darling tests, p-value $>0.4$ ) and homoscedasticity (Levene's test, $\mathrm{p}$-value $>0.10$ ), we found once again that the two groups were not significantly different (Student's t-test, $\mathrm{p}$-value $>0.09$ ). We also pooled the data by family in order to compare our results to Madden's analysis (fig. 30), but with the same result. In sum, our results indicate that extant foregut and hindgut fermenters cannot be separated from one another only using skull length and width of the temporal fossa as proxies for masticatory muscle mass.

The hindgut fermentation strategy seems to be the plesiomorphic condition for ungulates (Prothero and Foss, 2007). In view of the fact that there are no foregut fermenters in crown Perissodactyla, the extant group to which litopterns, notoungulates, and possibly other SANUs are most closely related (Welker et al., 2015; Buckley, 2015), phylogenetic bracketing predicts that litopterns were not either. Further insights may be provided by other predictive models not assessed here (e.g., Cassini et al., 2012a).

\section{CONCLUSIONS}

The various families of South American native ungulates grouped as Litopterna thrived on that continent from at least the late Paleogene to the beginning of the Holocene. The terminal taxa of Litopterna included the Macraucheniinae, characterized inter alia by a highly derived cranial structure, in which the nasal aperture was rotated to a position between the orbits, near the summit of the skull. This contribution presents a detailed study of the morphology of a newly discovered and nearly complete macraucheniine skull (IANIGLA-PV 29) from the Huayquerías Formation (Late Miocene, Huayquerian SALMA) in west-central Argentina (Mendoza Province). Referral of IANIGLA-PV 29 to Huayqueriana cf. H. cristata (Rovereto, 1914) (Litopterna, Macrauche- 
niidae, Macraucheniinae) is based on nonexclusive, but overwhelmingly similar, features occurring in Huayqueriana cristata.

Phylogenetic analysis failed to satisfactorily resolve the position of IANIGLA-PV 29 within Macraucheniinae, a result possibly influenced by intraspecific variation. Macraucheniinae is a monophyletic group with good support. We have emended the diagnosis of the subfamily to include derived features detected by our phylogenetic analysis.

Thanks to the availability of micro-CT scanning, we have been able to report much new information on the construction of the macraucheniine skull. Chief morphological findings may be grouped under these headings:

1. Reorganization of the nasal cavity: The nasal cavity extends into the rostrum, as in mammals generally, but this rostral portion (meatus nasi ventralis) is now merely a diverticulum of the "true," vertically oriented air pathway used in life. What this implies for the external soft-tissue structure of the face of Huayqueriana and other macraucheniines remains uncertain.

2. Foramina: Huayqueriana and its allies lacked a separate foramen rotundum. CT scanning also revealed that the maxillary nerve $(\mathrm{CN}$ $\mathrm{V}_{2}$ ) leaves the skull through the sphenoorbital fissure, a point previously in contention.

3. Pneumatization: Paranasal airspaces inflate much of the cranial vault, nasal region, and basicranium. By contrast, paratympanic pneumatization is slight.

4. Head orientation: The geometry of the lateral semicircular canal relative to the enclosing skull indicates that the head was habitually held at an appreciable angle, probably much as in modern horses.

5. Internal anatomy: The $3 \mathrm{D}$ reconstruction of the endocast, petrosal, and inner ear revealed the presence of several derived features that will provide information for future phylogenetic analyses (e.g., orbitotemporal canal running below the rhinal fissure along the lateroventral aspect of the piriform lobe; stapedial ratio $\sim 1.8$; very shallow subarcuate fossa; coiled cochlea with 2.2 full turns).

6. Body mass: Body mass estimation for fossil taxa, especially those having no close living relatives, presents many difficulties. Although our efforts to establish a plausible size for Huayqueriana were inconclusive, we believe that an estimate in the vicinity of $250 \mathrm{~kg}$ is much more likely than higher values.

7. Longevity: The extremely advanced dental wear seen in IANIGLA-PV 29 suggests that the animal was at the end of its natural life span. Cementum line counting indicates that it died at 10 to 11 years of age, which is lower than the expected lifespan of extant wild ungulates of similar body mass. This "accelerated aging" may be an outcome of ecosystem change in the Miocene and later, in South America, affecting the longevity of mesodont herbivores.

8. Digestion: Although it has been suggested that some litopterns were probably foregut fermenters (i.e., reliant on regurgitation, rechewing, and remixing of digestive fluids to ensure maximum extraction of nutrient value from food), our evaluation of the method is that it is at best inconclusive. There is no meaningful evidence that any macraucheniines were foregut fermenters.

\section{ACKNOWLEDGMENTS}

We acknowledge José Ginart for permission to allow our fieldwork on his land, "Las Aguadas del Sur." Field trips were made possible by the joint effort of F.J. Prevosti, A.C. Garrido, R. Bonini, S. Echarri, G. Turazzini (who found the IANIGLA-PV 29), C. Suarez, M. de la Fuente, F. Pujos, G. Re, M. Bourguet, B. Vera, and S. Kay. We especially acknowledge one anonymous reviewer and J.R. Wible for their enriching comments and suggestions. Early versions of the manuscript were improved by fruitful exchanges with E. Cerdeño, M. Bond, A. Kramarz, M.R. Sánchez-Villagra, C. Kolb, F. Bibi, and A. Martinelli. We acknowledge A.C. Garrido for the stratigraphic column of figure 
1; A. Martinelli and N. Nuñez for line drawings of figures $12-14,16$, and 22 , and 4 respectively; C. Kolb for helping in the processing of the tooth preparation for histological analysis and enriching discussions; S. Mahmood for the $3 \mathrm{D}$ reconstruction of the inner ear (fig. 21); G. Cassini for advice on the body mass estimation, especially for his patience given our recurrent questions; L. Cheme Arriaga for access to photographs and measurements; S.M. Devincenzi (IANIGLA), M. Reguero (MLP), J. Chiesa (UNSL), A. Kramarz and S. Álvarez (MACN), and Loïc Costeur (MMB) for permitting access to the collections under their care. We kindly thank M. Bourguet for the fossil preparation, Sergio Mosconi for scanning at FUESMEN and advice on digital files, and R. Trevan for 3D printing of the inner ear. The reconstruction of Huayqueriana cf. $H$. cristata was prepared with great skill by the artist J.L. Blanco. We acknowledge having used the Willi Hennig Society edition of TNT. This work is a contribution to the project PICT 2011-309 (ANPCyT) and the Fulbright-CONICET Scholar Program 2015-2016. EA was supported by the Swiss National Fund grant SNF 31003A_149605 to M. R. Sánchez-Villagra.

Author Contribution: Description of the skull, petrosal, inner ear (A.M.F., R.D.E.M.), endocast (S.H.P., A.M.F., R.D.E.M.), dentition (G.I.S.), and tooth histology (E.A.); construction of 3D models (S.H.P., C.G.); taxonomy and phylogeny (A.M.F., G.I.S.); body mass (S.H.P., G.I.S.), longevity (E.A.), and digestive physiology (E.A., A.M.F., R.D.E.M.). All authors have read and contributed to the final version of the manuscript.

\section{REFERENCES}

Ameghino, F. 1883a. Sobre una nueva colección de mamíferos fósiles recogidos por el Profesor Pedro Scalabrini en las barrancas del Paraná. Boletín de la Academia Nacional de Ciencias (Córdoba) 5: 257-306.

Ameghino, F. 1883b. Sobre una colección de mamíferos fósiles del piso mesopotámico de la formación patagónica recogidos por el Prof. Pedro Scalabrini. Boletín de la Academia Nacional de Ciencias (Córdoba) 5: 101-116.

Ameghino, F. 1885. Nuevos restos de mamíferos fósiles oligocenos recogidos por el Profesor Pedro Scalabrini y pertenecientes al Museo Provincial de la ciudad de Paraná. Boletín de la Academia Nacional de Ciencias (Córdoba) 8: 5-207.

Ameghino, F. 1887a. Apuntes preliminares sobre algunos mamíferos extinguidos del yacimiento de Monte Hermoso existentes en el Museo de La Plata. Boletín del Museo de La Plata 1: 1-20.

Ameghino, F. 1887b. Enumeración sistemática de las especies de mamíferos fósiles coleccionados por Carlos Ameghino en los terrenos eocenos de Patagonia Austral y depositados en el Museo La Plata. Boletín del Museo de La Plata 1: 1-26.

Ameghino, F. 1888. Rápidas diagnosis de algunos mamíferos fósiles nuevos de la República Argentina. 1-17. Buenos Aires: P.E. Coni e Hijos.

Ameghino, F. 1889. Contribución al conocimiento de los mamíferos fósiles de la República Argentina. Actas de la Academia Nacional de Ciencias de Córdoba 6: 1-1027, Atlas: 1-98.

Ameghino, F. 1891a. Caracteres diagnósticos de cincuenta especies nuevas demamíferos fósiles argentinos. Revista Argentina de Historia Natural 1: 129-167.

Ameghino, F. 1891b. Nuevos restos de mamíferos fósiles descubiertos por Carlos Ameghino en el Eoceno inferior de la Patagonia austral. Especies nuevas, adiciones y correcciones. Revista Argentina de Historia Natural 1: 289-328.

Ameghino, F. 1893. Apuntes preliminares sobre el género Theosodon. Revista del Jardín Zoológico de Buenos Aires 1: 20-29.

Ameghino, F. 1894. Enumération synoptique des espèces de mammifères fossiles des formations éocènes de Patagonie. Boletín de la Academia Nacional de Ciencias de Córdoba 13: 259-455.

Ameghino, F. 1902. Première contribution à la connaissance de la faune mammalogique des couches à Colpodon. Boletín de la Academia Nacional de Ciencias de Córdoba 17: 71-138.

Ameghino, F. 1908. Las formaciones sedimentarias de la región litoral de Mar del Plata y Chapalmalán. Anales del Museo Nacional de Historia Natural de Buenos Aires. Serie 3, 10: 343-428.

Billet, G., and C. de Muizon. 2013. External and internal anatomy of a petrosal from the Late Paleocene of Itaborai, Brazil, referred to Notoungulata (Plac- 
entalia). Journal of Vertebrate Paleontology 33: 455-469.

Billet, G., C. de Muizon, R. Schellhorn, I. Ruf, S. Ladevèze, and L. Bergqvist. 2015. Petrosal and inner ear anatomy and allometry amongst specimens referred to Litopterna (Placentalia). Zoological Journal of the Linnean Society 173: 956-987.

Bond, M. 1986. Los ungulados fósiles de Argentina: evolución y paleoambientes. 4to Congreso Argentino de Paleontología y Bioestratigrafía, Actas 2: 173-185.

Bond, M. 1999. Quaternary native ungulates of Southern South America. A synthesis. In J. Rabassa, and M. Salemme (editors), Quaternary of South America and Antarctic Peninsula: 177-205. Ushuaia: Centro Austral de Investigaciones Científicas and Universidad Nacional de la Patagonia.

Bond, M., E.P. Cerdeño, and G. López. 1995. Los ungulados nativos de América del Sur. In M.T. Alberdi, G. Leone, and E.P. Tonni (editors), Evolución biológica y climática de la región pampeana durante los últimos cinco millones de años. Un ensayo de correlación con el Mediterráneo occidental. 12: 259-275. Madrid: Monografías del Museo Nacional de Ciencias Naturales, CSIC.

Bond, M., D. Perea, M. Ubilla, and A.A. Tauber. 2001. Neolicaphrium recens Frenguelli, 1921, the only surviving Proterotheriidae (Litopterna, Mammalia) into the South American Pleistocene. Palaeovertebrata 30: 37-50.

Buckley, M. 2015. Ancient collagen reveals evolutionary history of the endemic South American "ungulates." Proceedings of the Royal Society B 282: 20142671.

Burmeister, G. 1864. Beschreibung der Macrauchenia patachonica Owen (Opisthorhinus falkoneri Brav.) nach A. Bravard's Zeichnungen und den im Museo zu Buenos Aires vorhandenen Resten entworfen. Abhandlung der Naturforscher Gesellschaft zu Halle 1: 75-112.

Cabrera, A. 1939. Sobre vertebrados fósiles del Plioceno de Adolfo Alsina. Revista del Museo de La Plata, Paleont. 2: 1-35.

Cabrera, A., and L. Kraglievich. 1931. Diagnosis previas de los ungulados fósiles del Arroyo Chasicó. Notas del Museo de La Plata 1: 107-113.

Cartelle, C., and G. Lessa. 1988. Descrição de um novo genero e espécie de Macraucheniidae (Mammalia, Litopterna) do Pleistoceno do Brasil. Paulacoutiana 3: 3-26.

Cassini, G.H., E. Cerdeño, A.L. Villafañe, and N.A. Muñoz. 2012a. Paleobiology of Santacrucian native ungulates (Meridiungulata: Astrapotheria, Litopterna, and Notoungulata). In S.F. Vizcaíno, R.F. Kay, and M.S. Bargo (editors), Early Miocene paleobiology in Patagonia: high-latitude paleocommunities of the Santa Cruz Formation: 243-286. Cambridge: Cambridge University Press.

Cassini, G.H., S.F. Vizcaíno, and M.S. Bargo. 2012b. Body mass estimation in Early Miocene native South American ungulates: a predictive equation based on 3D landmarks. Journal of Zoology 287: 53-64.

Caputa, M. 2004. Selective brain cooling: a multiple regulatory mechanism. Journal of Thermal Biology 29: 691-702.

Cerdeño, E., J. Chiesa, and G. Ojeda. 2008. Presence of Oxyodontherium (Macraucheniidae, Litopterna) in the Río Quinto Formation, San Luis (Argentina). Journal of South American Earth Sciences 25: 217-226.

Cerling, T.E., et al. 1997. Global vegetation change through the Miocene/Pliocene boundary. Nature 389: 153-159.

Christiansen, P., and J.M. Harris. 2005. Body size of Smilodon (Mammalia: Felidae). Journal of Morphology 266: 369-384.

Chritz, K.L., et al. 2009. Palaeobiology of an extinct Ice Age mammal: stable isotope and cementum analysis of giant deer teeth. Palaeogeography, Palaeoclimatology, Palaeoecology 282: 133-144.

Cifelli, R.L. 1983. The origin and affinities of the South American Condylarthra and early Tertiary Litopterna (Mammalia). American Museum Novitates 2772: 1-49.

Cifelli, R.L. 1993. The phylogeny of the native South American ungulates. In F.S. Szalay, M.J. Novacek, and M.C. McKenna (editors), Mammal phylogeny 2: 195-216. New York: Springer-Verlag.

Cifelli, R.L., and J. Guerrero. 1997. Litopterns. In R. Kay, R.H. Madden, R.L. Cifelli, and J.J. Flynn (editors), Vertebrate paleontology in the Neotropics: the Miocene fauna of La Venta, Colombia: 289302. Washington and London: Smithsonian Institution Press.

Cifelli, R.L., and M.F. Soria. 1983. Notes on Deseadan Macraucheniidae. Ameghiniana 20: 141-153.

Clauss, M, R. Frey, B. Kiefer, M. Lechner-Doll, W. Loehlein, C. Polster, G. Rössner, and W.J. Streich. 2003. The maximum attainable body size of herbivorous mammals: morphophysiological constraints on foregut, and adaptations of hindgut fermenters. Oecologia 136: 14-27. 
Cozzuol, M.A. 2006. The Acre vertebrate fauna: age, diversity, and geography. Journal of South American Earth Sciences 21: 185-203.

Daniel, P.M., J.D.K. Dawes, and M.L. Prichard. 1953. Studies of the carotid rete and its associated arteries. Philosophical Transactions of the Royal Society of London B 237: 173-208.

De Beer, G.R. 1947. How animals hold their heads. Proceedings of the Linnean Society of London 159: 125-139.

De Carles, E. 1911. Ensayo geológico descriptivo de las Guayquerías del Sur de Mendoza (Dep. de San Carlos). Anales del Museo Nacional de Historia Natural de Buenos Aires 22: 77-95.

De La Torre, E.D., and M.G. Netsky. 1960. Study of persistent primitive maxillary artery in human fetus: some homologies of cranial arteries in man and dog. American Journal of Anatomy 106: 193194.

Dessanti, R.N. 1946. Hallazgo de depósitos glaciales en las Huayquerías de San Carlos (Mendoza). Revista de la Sociedad Geológica Argentina 1: 270-284.

Dozo, M.T., and B. Vera. 2010. First skull and associated postcranial bones of Macraucheniidae (Mammalia, Litopterna) from the Deseadan SALMA (Late Oligocene) of Cabeza Blanca (Chubut, Argentina). Journal of Vertebrate Paleontology 30: 1818-1826.

Du Boulay, G. H. 1991 A note on the cerebral arteries of Perissodactyla: the rete caroticum of Diceros bicornis [and] dubious nomenclature of the internal carotid artery of horses. Neuroradiology 33 [suppl.]: 462-463.

Ekdale, E.G. 2013. Comparative anatomy of the bony labyrinth (inner ear) of placental mammals. PLoS One 8: e66624.

Ekdale, E.G. 2016. Form and function of the mammalian inner ear. Journal of Anatomy 228: 324-337.

Eronen, J.T., A.R. Evans, J. Jernvall, and M. Fortelius. 2010. The impact of regional climate on the evolution of mammals: a case study using fossil horses. Evolution 64: 398-408.

Esteban, G., N. Nasif, and S.M. Georgieff. 2014. Cronobioestratigrafía del Mioceno Tardío-Plioceno Temprano, Puerta de Corral Quemado y Villavil, provincia de Catamarca, Argentina. Acta Geológica Lilloana 26: 165-192.

Evans, H.E. 1993. Miller's anatomy of the dog. Philadelphia: W.B. Saunders.

Fariña, R.A., S.F. Vizcaíno, and M.S. Bargo. 1998. Body mass estimations in Lujanian (Late Pleistocene -
Early Holocene of South America) mammal megafauna. Mastozoología Neotropical 5: 87-108.

Fedorov, A., et al. 2012. 3D Slicer as an image computing platform for the quantitative imaging network. Magnetic Resonance Imaging 30: 1323-1341. PMID: 22770690. Online resource (http://www. slicer.org).

Fernández de Álvarez, E.H.E. 1940. Descripción de la Macrauchenia patachonica Owen y comparación con otros géneros terciarios (Theosodon, Scalabrinitherium y Promacrauchenia). Publicaciones de la FCEFN, UBA, serie B (Científico-Técnica) 19: 1-144 + lam. XXV.

Fletcher, M., C.M. Janis, and E.J. Rayfield. 2010. Finite element analysis of ungulate jaws: can mode of digestive physiology be determined? Palaeontologia Electronica 13 (3, 21A): 1-15.

Forasiepi, A.M., et al. 2014. The badlands from Mendoza and the Huayquerian Age: insights into the Late Miocene. 4th International Palaeontologial Congress, Abstracts: 713.

Forasiepi, A.M., et al. 2015a. Avances en el conocimiento de la fauna de la Formación Huayquerías (Mioceno Tardío, Mendoza). III Simposio del Mioceno-Pleistoceno, Abstracts.

Forasiepi, A.M., et al. 2015b. New toxodontid (Notoungulata) from the Early Miocene of Argentina: the extra-Patagonian fossil record. Paläontologische Zeitschrift 89: 611-634.

Fortelius, M. 1990. The mammalian dentition: a "tangled" view. Netherlands Journal of Zoology 40: 312-328.

Frenguelli, J. 1930. Las Guayquerías de San Carlos en la provincia de Mendoza. Universidad Nacional del Litoral Departamento de Extensión Universitaria 9: $7-54$.

Gabbert, S.L. 2004. The basicranial and posterior cranial anatomy of the families of the Toxodontia. In Gina C. Gould and Susan K. Bell (editors), Tributes to Malcolm C. McKenna: his students, his legacy. Bulletin of the American Museum of Natural History 285: 177-190.

García-López, D.A, and J.E. Powell. 2011. Griphotherion peiranoi, gen. et sp. nov., a new Eocene Notoungulata (Mammalia, Meridiungulata) from northwestern Argentina. Journal of Vertebrate Paleontology 31: 1117-1130.

Gervais, P. 1855. Recherches sur les mammifères fossiles de l'Amérique du Sud. Expédition dans les parties centrales de l'Amérique du Sud, de Rio de Janeiro à Lima, et de Lima au Para; exécuté par 
ordre du Gouvernement français pendant les années 1843 à 1847 sous la direction du comte Francis de Castelnau. Zoologie 7: 1-63.

Goin, F.J., C.I. Montalvo, and G. Visconti. 2000. Los marsupiales (Mammalia) del Mioceno superior de la Formación Cerro Azul (Provincia de La Pampa, Argentina). Estudios Geológicos 56: 101-126.

Goloboff, P., J. Farris, and K. Nixon. 2008. TNT, a free program for phylogenetic analysis. Cladistics 24: 774-786.

Graf, W., and F. Klam. 2006. Le système vestibulaire: anatomie fonctionnelle et comparée, évolution et développement. Comptes Rendus Palévol 5: 637-655.

Hershkovitz, P. 1977. Living New World monkeys (Platyrrhini), with an introduction to Primates, vol. 1. Chicago: University of Chicago Press.

Hiatt, J.L., and Gartner L.P. 2001. Textbook of head and neck anatomy, 3rd ed. Philadelphia: Lippincott Williams and Wilkins.

Holbrook, L.T. 2002. The unusual development of the sagittal crest in the Brazilian tapir (Tapirus terrestris). Journal of Zoology 256: 215-219.

Hullar, T.E. 2006. Semicircular canal geometry, afferent sensitivity, and animal behavior. Anatomical Record 288A: 466-472.

Janis, C.M. 1988. An estimation of tooth volume and hypsodonty indices in ungulate mammals, and the correlation of these factors with dietary preferences. In D.E. Russell, J.-P. Santoro and D. Sigogneau-Russell (editors), Teeth revisited: Proceedings of the VIIth International Symposium on Dental Morphology, Paris, 1986: 367-387. Paris: Mémoires du Muséum National d'Histoire Naturelle, series C.

Janis, C.M. 1990. Correlation of cranial and dental variables with body size in ungulates and macropodoids. In J. Damuth, and B.J. MacFadden (editors), Body size in mammalian paleobiology: estimation and biological implications: 255-300. Cambridge: Cambridge University Press.

Jernvall, J., and M. Fortelius. 2002. Common mammals drive the evolutionary increase of hypsodonty in the Neogene. Nature 417: 538-540.

Kampen, P.N. van. 1905. Die Tympanalgegend des Säugetierschädels. Morphologisches Jahrbuch 34: 321-722, figs. 1-96.

Klevezal, G.A. 1996. Recording structures of mammals. Determination of age and reconstruction of life history. Rotterdam: Balkema Publishers.

Kraglievich, L. 1930. La formación friaseana del Río Frías, Río Fénix, Laguna Blanca, etc. y su fauna de mamíferos. Physis 10: 127-161.
Kraglievich, L. 1934. La antigüedad Plioceno de las faunas de Monte Hermoso y Chapadmalal, deducidas de su comparación con las que le precedieron y sucedieron. Montevideo: Imprenta El Siglo Ilustrado.

Kraglievich, J.L., and A.G. Olazábal. 1959. Los prociónidos extinguidos del género Chapalmalania Ameghino. Revista del Museo Argentino de Ciencias Naturales "Bernardino Rivadavia," ciencias zoológicas 6: 1-59.

Kramarz, A.G., and M. Bond. 2008. Revision of Parastrapotherium (Mammalia, Astrapotheria) and other Deseadan astrapotheres of Patagonia. Ameghiniana 45: 537-551.

Linares, O.J. 1981. Tres nuevos carnívoros prociónidos fósiles del Mioceno de Norte y Sudamérica. Ameghiniana 18: 113-121.

Linares, O.J. 2004. Bioestratigrafia de la fauna de mamíferos de las formaciones Socorro, Urumaco y Codore (Mioceno Medio-Plioceno Temprano) de la región de Urumaco, Falcón, Venezuela. Paleobiologia Neotropical 1: 1-26.

Line, S.R.P., and L.P. Bergqvist. 2005. Enamel structure of Paleocene mammals of the São José de Itaboraí basin, Brazil. 'Condylarthra', Litopterna, Notoungulata, Xenungulata, and Astrapotheria. Journal of Vertebrate Paleontology 25: 924-928.

Loe, L.E., A. Mysterud, R. Langvatn, and N.C. Stenseth. 2003. Decelerating and sex-dependent tooth wear in Norwegian red deer. Oecologia 135: 346-353.

Luo, Z.X., I. Ruf, J.A. Schultz, and T. Martin. 2010. Fossil evidence on evolution of inner ear cochlea in Jurassic mammals. Proceedings of the Royal Society B 278: 28-34.

Lydekker, R. 1894. Contributions to knowledge of the fossil vertebrates of Argentina. 3. A study of extinct Argentine ungulates. Anales del Museo de La Plata, Paleontología 2: 1-91.

MacIntyre, G.T. 1972. The trisulcate petrosal pattern of mammals. In T. Dobzhansky, M.K. Hecht, and W.C. Steere (editors), Evolutionary Biology 6: 275-303. New York: Appleton-Century-Crofts.

MacPhee, R.D.E. 1981. Auditory regions of primate and eutherian insectivores: morphology, ontogeny, and character analysis. Contribution to Primatology 18: 1-282.

MacPhee, R.D.E. 1994. Morphology, adaptations, and relationships of Plesiorycteropus, and a diagnosis of a new order of eutherian mammals. Bulletin of the American Museum of Natural History 220: 1-214.

MacPhee, R.D.E. 2014. The serrialis bone, interparietals, "X" elements, entotympanics, and the com- 
position of the notoungulate caudal cranium. Bulletin of the American Museum of Natural History 384: 1-69.

Macrini, T.E., T Rowe, and M. Archer. 2006. Description of a cranial endocast from a fossil platypus, Obdurodon dicksoni (Monotremata, Ornithorhynchidae), and the relevance of endocranial characters to monotreme monophyly. Journal of Morphology 267: 1000-1015.

Macrini, T.E., T. Rowe, and J.L. Vandeberg. 2007a. Cranial endocasts from growth series of Monodelphis domestica (Didelphidae, Marsupialia): a study of individual and ontogenic variation. Journal of Morphology 268: 844-865.

Macrini, T.E., G.W. Rougier, and T. Rowe. 2007b. Description of a cranial endocast from the fossil mammal Vincelestes neuquenianus (Theriiformes) and its relevance to the evolution of endocranial characters in therians. Anatomical Record 290: 875-892.

Macrini, T.E., J.J. Flynn, D.A. Croft, and A.R. Wyss. 2010. Inner ear of a notoungulate placental mammal: anatomical description and examination of potentially phylogenetically informative characters. Journal of Anatomy 216: 600-610.

Macrini, T.E., J.J. Flynn, X. Ni, D.A. Croft, and A.R. Wyss. 2013. Comparative study of notoungulate (Placentalia, Mammalia) bony labyrinths and new phylogenetically informative inner ear characters. Journal of Anatomy 223: 442-461.

Madden, R.H. 2015. Hypsodonty in mammals: evolution, geomorphology and the role of Earth surface processes. Cambridge: Cambridge University Press.

Maier, W. 2002. Zur functionellen Morphologie der rostralen Nasenknorpel bei Soriciden. Mammalian Biology 67: 1-17.

Maier, W., A. Tröscher, and I. Ruf. 2013. The entotympanic of Equus caballus (Perissodactyla, Mammalia). Mammalian Biology 78: 231- 234.

Marcus, L.F., and E. Sarmiento. 1996. Variation in Myotragus balearicus and functional morphology of the skull and jaws compared to other ruminants. Journal of Vertebrate Paleontology 16 (3, Suppl): 50A.

Marshall, L.G., R. Hoffstetter, and R. Pascual. 1983. Mammals and stratigraphy: geochronology of the continental mammal-bearing Tertiary of South America. In Mammals and stratigraphy (Palaeovertebrata Memoire Extraordinaire), vol. 2:1-93. Montpellier: Laboratoire de Paléontologie des Vertébrés de l'Ecole Pratique des Hautes Études.

Marshall, L.G., et al. 1984. Mammals and stratigraphy: geochronology of the continental mammal-bearing
Quaternary of South America. Palaeovertebrata, Mem. Extr. 1-76.

Marshall, L.G., R.E. Drake, and G.H. Curtis. 1986. ${ }^{40} \mathrm{~K}-{ }^{40} \mathrm{Ar}$ calibration of Late Miocene-Pliocene mammal-bearing Huayquerías and Tunuyán formations, Mendoza province, Argentina. Journal of Paleontology 60: 448-457.

Mendoza, M., C.M. Janis, and P. Palmqvist. 2006. Estimating the body mass of extinct ungulates: a study on the use of multiple regression. Journal of Zoology 270: 90-101.

Meng J., and R.C. Fox. 1995. Osseous inner ear structures and hearing in early marsupials and placentals. Zoological Journal of the Linnean Society 115: 47-71.

Milewski, A., and E. Dierenfeld. 2013. Structural and functional comparison of the proboscis between tapirs and other extant and extinct vertebrates. Integrative Zoology 8: 84-94.

Miller, R.W. 1975. Western horse behavior and training. New York: Doubleday.

Millien, V., and Bovy, H. 2010. When teeth and bones disagree: body mass estimation of a giant extinct rodent. Journal of Mammalogy 91: 11-18.

Montalvo, C.I., R.N. Melchor, G. Visconti, and E. Cerdeño. 2008. Vertebrate taphonomy in loesspaleosol deposits: a case study from the Late Miocene of central Argentina. Geobios 41: 133-143.

Murie, J. 1872. On the Malayan tapir, Rhinochoerus sumatranus (Gray). Journal of Anatomy and Physiology 6: 31-169.

Napier, J.R., and P.H. Napier. 1967. A handbook of living primates. New York: Academic Press.

Nowak, R.M., and J.L. Paradiso. 1983. Walker's mammals of the world, 4 th ed. Baltimore: Johns Hopkins University Press.

Orihuela, J. 2014. Endocranial morphology of the extinct Antillean shrew Nesophontes (Lipotyphla: Nesophontidae) from natural and digital endocasts of Cuban taxa. Palaeontologia Electronica 17 (2,22a): 1-12.

Orliac, M.J., C. Argot, and E. Gilissen. 2012. Digital cranial endocast of Hyopsodus (Mammalia, "Condylarthra"): a case of Paleogene terrestrial echolocation? PLoS One 7 (2): 1-10.

Osman Hill, W.C. 1966. Primates: comparative anatomy and taxonomy. VI, Catarrhini, Cercopithecoidea: Cercopithecinae. Edinburgh: Edinburgh University Press.

Owen, R. 1838. Fossil Mammalia. In C.R. Darwin (editor), Zoology of the voyage of H.M.S Beagle, under 
the command of Captain Fitzroy, during the years 1832 to 1836 vol 1: 1-40. London: Smith Elder \& Co.

Parodi, L.J. 1931. Huesos de los miembros de los macroquénidos neoterciarios. Physis 10: 294-304.

Pascual, R. 1966. Litopterna. In A.V. Borrello (editor), Paleontografía Bonaerense. IV Vertebrata: 161-168. La Plata: Comisión de Investigación Científica.

Pascual, R., and M.S. de la Fuente. 1993. Vertebrados fósiles cenozoicos. XII Congreso Geológico Argentino y II Congreso de Exploración de Hidrocarburos, Relatorio 2: 357-363.

Patterson, B. 1932. On the auditory region of the Toxodontia. Field Museum of Natural History, Geology 6: 1-27.

Patterson, B. 1934. The auditory region of an upper Pliocene typotherid. Field Museum of Natural History, Geology 6: 83-89.

Paula Couto, C. de 1945. Sobre un macrauquénido gigante, Macraucheniopsis gen. nov. del pampeano inferior de la Argentina. Notas del Museo de La Plata 10: 233-257.

Prothero, D.R, and S.E. Foss. 2007. The evolution of artiodactyls. Baltimore: Johns Hopkins University Press.

Racicot, R., and M. Colbert. 2002. Tursiops truncatus. Online resource (http://digimorph.org/specimens/ Tursiops_truncatus/).

Rager, L., L. Hautier, A.M. Forasiepi, A. Goswami, and M.R. Sánchez-Villagra. 2014. Timing in cranial suture closure in placental mammals: phylogenetic patterns, intraspecific variation, and comparison with marsupials. Journal of Morphology 275: 125-140.

Reguero, M.A., and A.M. Candela 2011. Late Cenozoic mammals from Northwest of Argentina. In J.A. Salfity, and R.A. Marquillas (editors), Cenozoic geology of Central Andes of Argentina: 411-426. Salta: Instituto del Cenozoico (INCE).

Reguero, M.A., A.M. Candela, and R.E. Alonso. 2007. Biochronology and biostratigraphy of the Uquía Formation (Pliocene-Early Pleistocene, NW of Argentina) and its significance in the Great American Biotic Interchange. Journal of South American Earth Sciences 23: 1-16.

Ribeiro, A.M., et al. 2013. Mamíferos fósiles y biocronología en el suroeste de la Amazonia, Brasil. In D. Brandoni, and J.I. Noriega (editors), El Neógeno de la Mesopotamia argentina: 207-221. Buenos Aires: Asociación Paleontológica Argentina.

Riggs, E.S., and B. Patterson. 1939. Stratigraphy of Late Miocene and Pliocene deposits of the Province of Catamarca (Argentina). With notes on the faunae. Physis 14: 143-162.
Roth, S. 1903. Los ungulados sudamericanos. Anales del Museo de La Plata. Sección Paleontología 5: 1-36.

Rougier, G.W., J.R. Wible, and J.A. Hopson. 1992. Reconstruction of the cranialvessels in the Early Cretaceous mammal Vincelestes neuquenianus: implications for the evolution of the mammalian cranial vascular system. Journal of Vertebrate Paleontology 12: 188-216.

Rovereto, C. 1914. Los estratos araucanos y sus fósiles. Anales del Museo Nacional de Historia Natural de Buenos Aires 25: 1-247.

Rowe, T.B. 1996. Coevolution of the mammalian middle ear and neocortex. Science 273: 651-654.

Rusconi, C. 1932. Nuevos restos de Scalabrinitherium del Terciario de Paraná y apuntes relativos a su anatomía craneana. Revista de Medicina y Veterinaria 15-19: 3-18.

Rusconi, C. 1939. Lista de los mamíferos miocénicos de las Huayquerías de Mendoza. Physis 14: 461-471.

Rusconi, C. 1957. Evolución de la trompa en las macrauquenias. Revista del Museo de Historia Natural de Mendoza 10: 111-118.

Schaller, O. 1992. Illustrated veterinary anatomical nomenclature. Stuttgart: Ferdinand Enke Verlag.

Scherer, C.S., V.G. Pitana, and A.M. Ribeiro. 2009. Proterotheriidae and Macraucheniidae (Litopterna, Mammalia) from the Pleistocene of Rio Grande do Sul State, Brazil. Revista Brasileira de Paleontologia 12: 231-246.

Schmelzle, T., M.R. Sánchez-Villagra, and W. Maier. 2007. Vestibular labyrinth evolution in diprotodontian marsupial mammals. Mammal Study 32: 83-97.

Schmidt, G.I. 2013. Litopterna y Notoungulata (Mammalia) de la Formación Ituzaingó (Mioceno TardíoPlioceno) de la Provincia de Entre Ríos: sistemática, bioestratigrafía y paleobiogeografía. Ph.D. thesis. La Plata: Universidad Nacional de La Plata.

Schmidt G.I., and E. Cerdeño. 2013. Los ungulados nativos (Litopterna y Notoungulata: Mammalia) del "Mesopotamiense" (Mioceno Tardío) de Entre Ríos, Argentina. In D. Brandoni, and J.I. Noriega (editors), El Neógeno de la Mesopotamia argentina: 145-152. Buenos Aires: Asociación Paleontológica Argentina.

Schmidt, G.I., and B.S. Ferrero. 2014. Taxonomic reinterpretation of Theosodon hystatus Cabrera and Kraglievich, 1931 (Litopterna, Macraucheniidae) and phylogenetic relationships of the family. Journal of Vertebrate Paleontology 34: 1231-1238.

Schmidt-Nielsen, K. 1984. Scaling: why is animal size so important? Cambridge: Cambridge University Press. 
Scott, W.B. 1910. Mammalia of the Santa Cruz beds. Part I. Litopterna. Reports of the Princeton University Expedition to Patagonia 7: 1-156.

Scott, W.B. 1937. A history of land mammals in the Western Hemisphere, revised ed. New York: MacMillan.

Sefve, I. 1925. Macrauchenia patagonica [sic]. Bulletin of the Geological Institution of the University of Upsala 19: 1-21

Silcox, M.T., et al. 2011. Endocranial morphology of Labidolemur kayi (Apatemyidae, Apotheria) and its relevance to the study of brain evolution in Euarchontoglires. Journal of Vertebrate Paleontology 31: 1314-1325.

Silva, M., and J.A. Downing. 1995. CRC handbook of mammalian body masses. Boca Raton: CRC Press.

Simpson, G.G. 1933. Braincasts of two typotheres and a litoptern. American Museum Novitates 629: 1-18.

Simpson, G.G. 1936. Structure of a primitive notoungulate cranium. American Museum Novitates 824: 1-31.

Simpson, G.G. 1940. Review of the mammal-bearing Tertiary of South America. Proceedings of the American Philosophical Society 83: 649-709.

Sisson, S., and J.D. Grossman. 1975. The anatomy of the domestic animals. R. Getty (editor), 5th ed. Philadelphia: Saunders.

Skogland, T. 1988. Tooth wear by food limitation and its life history consequences in wild reindeer. Oikos 51: 238-242.

Soria, M.F. 1981. Los Litopterna del Colhuehuapense (Oligoceno Tardío) de la Argentina. Revista del Museo Argentino de Ciencias Naturales "Bernardino Rivadavia," Serie Paleontología 3: 1-54.

Soria, M.F. 1986. Huayqueriana Kraglievich, 1934, género de Macraucheniidae (Litopterna) de edad Huayqueriense (Mioceno Tardío). Aspectos evolutivos vinculados. IV Congreso Argentino de Paleontología y Bioestratigrafía, Actas: 157-164.

Soria, M.F. 2001. Los Proterotheriidae (Mammalia, Litopterna): sistemática, origen y filogenia. Monografías del Museo Argentino de Ciencias Naturales "Bernardino Rivadavia" 1: 1-167.

Tacutu, R., et al. 2013. Human ageing genomic resources: integrated databases and tools for the biology and genetics of ageing. Nucleic Acids Research 41: D1027-D1033.

Todd, N.E. 2010. Qualitative comparison of the craniodental osteology of the extant elephants, Elephas maximus (Asian elephant) and Loxodonta africana (African elephant). Anatomical Record 293: 62-73.
Tonni E.P. 1990. Mamíferos del Holoceno en la Provincia de Buenos Aires. Paulacoutiana 4: 3-21.

Verzi, D.H., E.C. Vieytes, and C.I. Montalvo. 2011. Dental evolution in Neophanomys (Rodentia, Octodontidae) from the Late Miocene of central Argentina. Geobios 44: 621-633.

Villagra, P.E., et al. 2011. Ser planta en el desierto: estrategias de uso de agua y resistencia al estrés hídrico en el Monte Central de Argentina. Ecología Austral 21: 29-42.

Vizcaíno, S.F., M.S. Bargo, and G.H. Cassini. 2006. Dental occlusal surface area in relation to body mass, food habits and other biological features in fossil xenarthrans. Ameghiniana 43: 11-26.

Vizcaíno, S.F., G.H. Cassini, N. Toledo, and M.S. Bargo. 2012. On the evolution of large size mammalian herbivores of the Cenozoic faunas of southern South America. In B.D. Patterson, and E. Costa (editors), Bones, clones, and biomes: the history and geography of recent Neotropical mammals: 76-101. Chicago: University of Chicago Press.

Vogt, C. 2011. Lehrbuch der Zahnheilkunde beim Pferd. Stuttgart: Schattauer.

von Mering, F. 1994. Zur Morphogenese der Regio ethmoidalis von Equus (Perisssodactyla: Equidae). Diplomarbeit der Fakultät für Biologie der Eberhard-Karls, Universität Tübingen.

Wall, W.P. 1980. Cranial evidence for a proboscis in Cadurcodon and a review of snout structure in the family Amynodontidae (Perissodactyla, Rhinocerotoidea). Journal of Paleontology 54: 968-977.

Welker, F., et al. 2015. Ancient proteins resolve the evolutionary history of Darwin's South American ungulates. Nature 522: 81-4.

West, C.D. 1985. The relationship of the spiral turns of the cochlea and the length of the basilar membrane to the range of audible frequencies in ground dwelling mammals. Journal of the Acoustical Society of America 77: 1091-101.

Wible, J.R. 1987. The eutherian stapedial artery: character analysis and implications for superordinal relationships. Zoological Journal of the Linnean Society 91: 107-135.

Wible, J.R. 1993. Cranial circulation and relationships of the colugo Cynocephalus (Dermoptera, Mammalia). American Museum Novitates 3072: 1-27.

Wible, J.R. 2003. On the cranial osteology of the shorttailed opossum Monodelphis brevicaudata (Didelphidae, Marsupialia). Annals of Carnegie Museum 72: 137-202. 
Wible, J.R. 2008. On the cranial osteology of the Hispaniolan solenodon, Solenodon paradoxus Brandt, 1893 (Mammalia, Lipotyphla, Solenodontidae). Annals of the Carnegie Museum 73: 117-196.

Wible, J.R. 2010. Petrosal anatomy of the nine-banded armadillo, Dasypus novemcinctus Linneaus, 1758 (Mammalia, Xenarthra, Dasypodidae). Annals of Carnegie Museum 79: 1-28.

Wible, J.R. 2012. The ear region of the aardvark, Orycteropus afer (Pallas, 1766) (Mammalia, Placentalia, Tubulidentata). Annals of Carnegie Museum 80: 115-146.

Wible, J.R, and T.J. Gaudin. 2004. On the cranial osteology of the yellow armadillo Euphractus sexcinctus (Dasypodidae, Xenarthra, Placentalia). Annals of Carnegie Museum 73: 117-196.

Wible, J.R, and M. Spaulding. 2013. On the cranial osteology of the African palm civet, Nandinia Bino- tata (Gray, 1830) (Mammalia, Carnivora, Feliformia). Annals of Carnegie Museum 82: 1-114.

Witmer, L.M., S.D. Sampson, and N. Solounias. 1999. The proboscis of tapirs (Mammalia: Perissodactyla): a case study in novel narial anatomy. Journal of Zoology 249: 249-267.

Yrigoyen, M.R. 1993. Los depósitos sinorogénicos terciarios. Geología y recursos naturales de Mendoza. XII Congreso Geológico Argentino y II Congreso de Explotación de Hidrocarburos, Relatorio 1: 123148.

Yrigoyen, M.R. 1994. Revisión estratigráfica del Neógeno de las Huayquerías de Mendoza septentrional, Argentina. Ameghiniana 31: 125-138.

Zachos, J., M. Pagani, L. Sloan, E. Thomas, and K. Billups. 2001. Trends, rhythms, and aberrations in global climate 65 Ma to present. Science 292: 686-693. 
APPENDIX 1

Comparative Set: Litopterna

\begin{tabular}{|c|c|c|c|c|c|c|}
\hline Family & Species & Specimen & Locality & Stratigraphy & Age/SALMA & $\begin{array}{l}\text { Major } \\
\text { Reference }\end{array}$ \\
\hline \multirow[t]{2}{*}{ Proterotheriidae } & $\begin{array}{l}\text { Tetramerorhinus } \\
\text { lucarius Ameghino, } \\
1894\end{array}$ & $\begin{array}{l}\text { AMNH } \\
9245\end{array}$ & $\begin{array}{l}\text { Felton's Estan- } \\
\text { cia; Santa Cruz }\end{array}$ & $\begin{array}{l}\text { Santa Cruz } \\
\text { Formation }\end{array}$ & $\begin{array}{l}\text { E. Miocene/ } \\
\text { Santacrucian }\end{array}$ & $\begin{array}{l}\text { Simpson, } \\
1933^{1}\end{array}$ \\
\hline & $\begin{array}{l}\text { Tetramerorhinus } \\
\text { cingulatum } \\
\text { (Ameghino, 1891b) }\end{array}$ & $\begin{array}{l}\text { MACN-A } \\
5971\end{array}$ & $\begin{array}{l}\text { La Cueva; } \\
\text { Santa Cruz }\end{array}$ & $\begin{array}{l}\text { Santa Cruz } \\
\text { Formation }\end{array}$ & $\begin{array}{l}\text { E. Miocene/ } \\
\text { Santacrucian }\end{array}$ & Soria, 2001 \\
\hline \multirow[t]{4}{*}{$\begin{array}{l}\text { Macraucheniidae } \\
\text { Cramauche- } \\
\text { niinae }\end{array}$} & $\begin{array}{l}\text { Cramauchenia } \\
\text { normalis Ameghino, } \\
1902\end{array}$ & $\begin{array}{l}\text { MACN-A } \\
52-219\end{array}$ & $\begin{array}{l}\text { Gran Bar- } \\
\text { ranca; Chubut }\end{array}$ & $\begin{array}{l}\text { Sarmiento } \\
\text { Formation }\end{array}$ & $\begin{array}{l}\text { E. Miocene/ } \\
\text { Colhuehuapian }\end{array}$ & $\begin{array}{l}\text { Dozo and } \\
\text { Vera, } 2010\end{array}$ \\
\hline & $\begin{array}{l}\text { Cramauchenia } \\
\text { normalis Ameghino, } \\
1902\end{array}$ & $\begin{array}{l}\text { MPEF-PV } \\
2524\end{array}$ & $\begin{array}{l}\text { Cabeza Blanca; } \\
\text { Chubut }\end{array}$ & $\begin{array}{l}\text { Sarmiento } \\
\text { Formation }\end{array}$ & $\begin{array}{l}\text { L. Oligocene/ } \\
\text { Deseadan }\end{array}$ & $\begin{array}{l}\text { Dozo and } \\
\text { Vera, } 2010\end{array}$ \\
\hline & $\begin{array}{l}\text { Theosodon lydekkeri } \\
\text { Ameghino, } 1887 \mathrm{~b}\end{array}$ & $\begin{array}{l}\text { MACN-A } \\
9269\end{array}$ & $\begin{array}{l}\text { Corriguen } \\
\text { Aike; Santa } \\
\text { Cruz }\end{array}$ & $\begin{array}{l}\text { Santa Cruz } \\
\text { Formation }\end{array}$ & $\begin{array}{l}\text { E. Miocene/ } \\
\text { Santacrucian }\end{array}$ & $\begin{array}{l}\text { Cassini et al., } \\
2012 \mathrm{a}\end{array}$ \\
\hline & $\begin{array}{l}\text { Theosodon garret- } \\
\text { torum Scott, } 1910\end{array}$ & $\begin{array}{l}\text { PIMUZ } \\
\text { A/V } 4662\end{array}$ & $\begin{array}{l}\text { Locality not } \\
\text { indicated, } \\
\text { Santa Cruz }\end{array}$ & $\begin{array}{l}\text { Santa Cruz } \\
\text { Formation }\end{array}$ & $\begin{array}{l}\text { E. Miocene/ } \\
\text { Santacrucian }\end{array}$ & $\begin{array}{l}\text { Cassini et al., } \\
\text { 2012a }\end{array}$ \\
\hline \multirow[t]{9}{*}{$\begin{array}{l}\text { Macraucheniidae } \\
\text { Macraucheniinae }\end{array}$} & $\begin{array}{l}\text { Huayqueriana } \\
\text { cristata (Rovereto, } \\
1914 \text { ) }\end{array}$ & $\begin{array}{l}\text { MACN-PV } \\
8463^{2}\end{array}$ & $\begin{array}{l}\text { Huayquerías } \\
\text { de San Carlos; } \\
\text { Mendoza }\end{array}$ & $\begin{array}{l}\text { Huayquerías } \\
\text { Formation }\end{array}$ & $\begin{array}{l}\text { L. Miocene/ } \\
\text { Huayquerian }\end{array}$ & Soria, 1986 \\
\hline & $\begin{array}{l}\text { Huayqueriana } \\
\text { cristata (Rovereto, } \\
1914 \text { ) }\end{array}$ & $\begin{array}{l}\text { MLP 41-IV- } \\
29-4\end{array}$ & $\begin{array}{l}\text { Huayquerías } \\
\text { de San Carlos; } \\
\text { Mendoza }\end{array}$ & $\begin{array}{l}\text { Huayquerías } \\
\text { Formation }\end{array}$ & $\begin{array}{l}\text { L. Miocene/ } \\
\text { Huayquerian }\end{array}$ & Soria, 1986 \\
\hline & $\begin{array}{l}\text { Huayqueriana } \\
\text { cristata (Rovereto, } \\
1914 \text { ) }\end{array}$ & $\begin{array}{l}\text { MLP } \\
\text { 37-III-7-2 }\end{array}$ & $\begin{array}{l}\text { Adolfo Alsina; } \\
\text { Buenos Aires }\end{array}$ & $\begin{array}{l}\text { Epecuén For- } \\
\text { mation }\end{array}$ & $\begin{array}{l}\text { L. Miocene/ } \\
\text { Huayquerian }\end{array}$ & Soria, 1986 \\
\hline & $\begin{array}{l}\text { Macrauchenia } \\
\text { patachonica Owen, } \\
1838\end{array}$ & $\begin{array}{l}\text { MACN-PV } \\
2\end{array}$ & $\begin{array}{l}\text { Near Salto, } \\
\text { Buenos Aires }\end{array}$ & $\begin{array}{l}\text { Pampeano } \\
\text { Formation }\end{array}$ & $\begin{array}{l}\text { Pleistocene- } \\
\text { Holocene }\end{array}$ & $\begin{array}{l}\text { Burmeister, } \\
\text { 1864; Fernán- } \\
\text { dez de Álva- } \\
\text { rez, } 1940\end{array}$ \\
\hline & $\begin{array}{l}\text { Macrauchenia } \\
\text { patachonica Owen, } \\
1838\end{array}$ & $\begin{array}{l}\text { MLP } \\
12-1424\end{array}$ & $\begin{array}{l}\text { Arrecifes, Bue- } \\
\text { nos Aires }\end{array}$ & $\begin{array}{l}\text { Pampeano } \\
\text { Formation }\end{array}$ & $\begin{array}{l}\text { Pleistocene- } \\
\text { Holocene }\end{array}$ & Sefve, 1925 \\
\hline & $\begin{array}{l}\text { Macraucheniopsis } \\
\text { ensenadensis } \\
\text { (Ameghino, 1888) }\end{array}$ & $\begin{array}{l}\text { MLP } \\
12-1426\end{array}$ & $\begin{array}{l}\text { Locality not } \\
\text { indicated, } \\
\text { Buenos Aires }\end{array}$ & $\begin{array}{l}\text { Pampeano } \\
\text { Formation }\end{array}$ & $\begin{array}{l}\text { E Pleistocene/ } \\
\text { Ensenadan }\end{array}$ & $\begin{array}{l}\text { Paula Couto, } \\
1945\end{array}$ \\
\hline & $\begin{array}{l}\text { Oxyodontherium } \\
\text { zeballosi Ameghino, } \\
\text { 1883a }\end{array}$ & $\begin{array}{l}\text { MACN-PV } \\
13671\end{array}$ & $\begin{array}{l}\text { Conglomerado } \\
\text { Osífero; Entre } \\
\text { Ríos }\end{array}$ & $\begin{array}{l}\text { Ituzaingó } \\
\text { Formation }\end{array}$ & $\begin{array}{l}\text { L. Miocene/ } \\
\text { "Mesopota- } \\
\text { mian" }\end{array}$ & $\begin{array}{l}\text { Schmidt, } \\
2013\end{array}$ \\
\hline & $\begin{array}{l}\text { Oxyodontherium } \\
\text { zeballosi Ameghino, } \\
\text { 1883a }\end{array}$ & $\begin{array}{l}\text { MACN-PV } \\
17745^{3}\end{array}$ & $\begin{array}{l}\text { Conglomerado } \\
\text { Osífero; Entre } \\
\text { Ríos }\end{array}$ & $\begin{array}{l}\text { Ituzaingó } \\
\text { Formation }\end{array}$ & $\begin{array}{l}\text { L. Miocene/ } \\
\text { "Mesopota- } \\
\text { mian" }\end{array}$ & $\begin{array}{l}\text { Schmidt, } \\
2013\end{array}$ \\
\hline & $\begin{array}{l}\text { Oxyodontherium } \\
\text { zeballosi Ameghino, } \\
\text { 1883a }\end{array}$ & $\begin{array}{l}\text { MHIN- } \\
\text { UNSL-GEO- } \\
\text { V 465a }\end{array}$ & $\begin{array}{l}\text { Arroyo La } \\
\text { Petra; San Luis }\end{array}$ & $\begin{array}{l}\text { Río Quinto } \\
\text { Formation }\end{array}$ & $\begin{array}{l}\text { L Miocene/ } \\
\text { Huayquerian }\end{array}$ & $\begin{array}{l}\text { Cerdeño et } \\
\text { al. } 2008\end{array}$ \\
\hline
\end{tabular}




\begin{tabular}{|c|c|c|c|c|c|c|}
\hline Family & Species & Specimen & Locality & Stratigraphy & Age/SALMA & $\begin{array}{l}\text { Major } \\
\text { Reference }\end{array}$ \\
\hline & $\begin{array}{l}\text { Paranauchenia } \\
\text { hystata (Cabrera } \\
\text { and Kraglievich, } \\
\text { 1931) }\end{array}$ & $\begin{array}{l}\text { MLP 29-IX- } \\
1-75\end{array}$ & $\begin{array}{l}\text { Arroyo Cha- } \\
\text { sicó, } \\
\text { Buenos Aires }\end{array}$ & $\begin{array}{l}\text { Chasicó } \\
\text { Formation }\end{array}$ & $\begin{array}{l}\text { L Miocene/ } \\
\text { Chasicoan }\end{array}$ & $\begin{array}{l}\text { Schmidt and } \\
\text { Ferrero, } 2014\end{array}$ \\
\hline & $\begin{array}{l}\text { Paranauchenia den- } \\
\text { ticulata (Ameghino, } \\
\text { 1891a) }\end{array}$ & $\begin{array}{l}\text { MACN-PV } \\
4444\end{array}$ & $\begin{array}{l}\text { Conglomerado } \\
\text { Osífero; Entre } \\
\text { Ríos }\end{array}$ & $\begin{array}{l}\text { Ituzaingó } \\
\text { Formation }\end{array}$ & $\begin{array}{l}\text { L Miocene/ } \\
\text { "Mesopota- } \\
\text { mian" }\end{array}$ & $\begin{array}{l}\text { Schmidt, } \\
2013\end{array}$ \\
\hline & $\begin{array}{l}\text { Promacrauchenia } \\
\text { antiquua } \\
\text { (Ameghino, 1887a) }\end{array}$ & $\begin{array}{l}\text { MACN-PV } \\
7986\end{array}$ & $\begin{array}{l}\text { Monte Her- } \\
\text { moso, Buenos } \\
\text { Aires }\end{array}$ & $\begin{array}{l}\text { Monte Her- } \\
\text { moso Forma- } \\
\text { tion }\end{array}$ & $\begin{array}{l}\text { E Pliocene/ } \\
\text { Montehermo- } \\
\text { san }\end{array}$ & $\begin{array}{l}\text { Fernández de } \\
\text { Álvarez, } 1940\end{array}$ \\
\hline & $\begin{array}{l}\text { Promacrauchenia } \\
\text { calchaquiorum } \\
\text { Rovereto, } 1914\end{array}$ & $\begin{array}{l}\text { MACN-PV } \\
5528^{2}\end{array}$ & $\begin{array}{l}\text { Valle de Santa } \\
\text { María, Cata- } \\
\text { marca }\end{array}$ & $\begin{array}{l}\text { "Estratos } \\
\text { Araucanos"5 }\end{array}$ & $\begin{array}{l}\text { L Miocene- } \\
\text { Pliocene/Cha- } \\
\text { sicoan to } \\
\text { Montehermosan }\end{array}$ & $\begin{array}{l}\text { Rovereto, } \\
1914\end{array}$ \\
\hline & $\begin{array}{l}\text { Scalabrinitherium } \\
\text { bravardi Ameghino, } \\
1883 \mathrm{~b}\end{array}$ & $\begin{array}{l}\text { MACN-PV } \\
4414^{6}\end{array}$ & $\begin{array}{l}\text { Conglomerado } \\
\text { Osífero; Entre } \\
\text { Ríos }\end{array}$ & $\begin{array}{l}\text { Ituzaingó } \\
\text { Formation }\end{array}$ & $\begin{array}{l}\text { L Miocene/ } \\
\text { "Mesopota- } \\
\text { mian" }\end{array}$ & $\begin{array}{l}\text { Schmidt, } \\
2013\end{array}$ \\
\hline & $\begin{array}{l}\text { Scalabrinitherium } \\
\text { bravardi Ameghino, } \\
1883 \mathrm{~b}\end{array}$ & $\begin{array}{l}\text { MACN } \\
\text { A-1270 }\end{array}$ & $\begin{array}{l}\text { Conglomerado } \\
\text { Osífero; Entre } \\
\text { Ríos }\end{array}$ & $\begin{array}{l}\text { Ituzaingó } \\
\text { Formation }\end{array}$ & $\begin{array}{l}\text { L Miocene/ } \\
\text { "Mesopota- } \\
\text { mian" }\end{array}$ & $\begin{array}{l}\text { Schmidt, } \\
2013\end{array}$ \\
\hline & $\begin{array}{l}\text { Scalabrinitherium } \\
\text { bravardi Ameghino, } \\
1883 \mathrm{~b}\end{array}$ & $\begin{array}{l}\text { MACN-PV } \\
8903\end{array}$ & $\begin{array}{l}\text { Conglomerado } \\
\text { Osífero; Entre } \\
\text { Ríos }\end{array}$ & $\begin{array}{l}\text { Ituzaingó } \\
\text { Formation }\end{array}$ & $\begin{array}{l}\text { L Miocene/ } \\
\text { "Mesopota- } \\
\text { mian" }\end{array}$ & $\begin{array}{l}\text { Schmidt, } \\
2013\end{array}$ \\
\hline & $\begin{array}{l}\text { Scalabrinitherium } \\
\text { bravardi Ameghino, } \\
\text { 1883b }\end{array}$ & $\begin{array}{l}\text { MACN-PV } \\
13082\end{array}$ & $\begin{array}{l}\text { Conglomerado } \\
\text { Osífero; Entre } \\
\text { Ríos }\end{array}$ & $\begin{array}{l}\text { Ituzaingó } \\
\text { Formation }\end{array}$ & $\begin{array}{l}\text { L Miocene/ } \\
\text { "Mesopota- } \\
\text { mian" }\end{array}$ & $\begin{array}{l}\text { Rusconi, } \\
1932^{7}\end{array}$ \\
\hline & $\begin{array}{l}\text { Xenorhinotherium } \\
\text { bahiense } \\
\text { Cartelle and Lessa, } \\
1988\end{array}$ & MCL-2644 & $\begin{array}{l}\text { Gruta dos } \\
\text { Ossos } \\
\text { Estado da } \\
\text { Bahia }\end{array}$ & N/A & Holocene & $\begin{array}{l}\text { Cartelle and } \\
\text { Lessa, } 1988\end{array}$ \\
\hline & $\begin{array}{l}\text { Windhausenia dela- } \\
\text { croixi Kraglievich, } \\
1930\end{array}$ & $\begin{array}{l}\text { MACN PV } \\
5301\end{array}$ & Uquía, Jujuy & $\begin{array}{l}\text { Uquía Forma- } \\
\text { tion }\end{array}$ & $\begin{array}{l}\text { L. Plioc / } \\
\text { Vorohuean- } \\
\text { Sanandresian }\end{array}$ & $\begin{array}{l}\text { Kraglievich, } \\
1930 \text {; } \\
\text { Reguero et } \\
\text { al., } 2007\end{array}$ \\
\hline
\end{tabular}

${ }^{1}$ Specimen originally assigned to "Proterotherium cavum" Ameghino 1887b, but taxonomy here follows Soria (2001:42).

${ }^{2}$ Holotype.

${ }^{3}$ Young adult, unworn M3.

${ }^{4}$ Juvenile.

${ }^{5}$ According to MACN catalog, the stratigraphic location of Pr. calchaquiorum is the "Araucana Fm" (an informal unit formed by the Chiquimil, Andalhuala and Corral Quemado formations, ranging from $\sim 12$ to $\sim 3 \mathrm{Ma}$ ). No precise data is available to determine the age of the specimen (Bonini, com. per. 2015).

${ }^{6}$ Cast of the holotype.

${ }^{7}$ We follow Rusconi's assignment of this partial skull to S. bravardi. 


\section{APPENDIX 2}

\section{Phylogenetic Analysis}

Data matrix based on Schmidt and Ferrero (2014), with modifications in wording for certain characters and characters states (characters 1-5, $8,10-12,15,18,19,21,23)$, plus eight additional characters (characters 26-34).

\section{List OF CHARACTERS}

AbBreviations: *, additive character

1. Development of nasals *

0 developed, overhanging the nasal aperture

1 reduced

2 vestigial or absent

2. Nasal aperture, caudal border

0 anterior to orbit

1 level with orbit

3. Anterior palatal shape

0 lateral borders almost parallel

1 narrowing at P2 or P3 level

4. Orbit, postorbital bar *

0 open (large gap)

1 open (small gap)

2 closed

5. Outline of premaxillary area in palatal view

0 acute

1 rounded

6. Premaxillary area in lateral view

0 slightly ventrally curved

1 straight

7. Frontal fossae on caudal margin of nasal aperture

0 absent

1 present

8. Height of tooth crown (HI: crown height/ labio-lingual width; Janis, 1988) based on m3 when possible

0 brachyodont $(\mathrm{HI}<1.45)$

1 mesodont $(\mathrm{HI}=$ or $>1.45)$
9. Diastema between I3-C

0 present

1 absent

10. Parastyle on P3-P4

0 labially projected

1 level with mesostyle and metastyle

11. Concavities between lingual styles (parastylemesostyle-metastyle) on M1-M3

0 shallow

1 deep

12. Position of hypocone on M1-M2

0 hypocone level with metacone

1 hypocone near protocone, mesial to metacone

13. Position of hypocone vs protocone on M2 0 hypocone labial to protocone 1 hypocone lingual to protocone

14. Anterolingual cingulum (precingulum) on M1-M2

0 noticeably more lingual than posterolingual cingulum

1 slightly lingual or at same level as posterolingual cingulum

15. Hypolophulid on $\mathrm{p} 4$

0 shorter than paralophid

1 similar in length to paralophid

16. Entolophid on $\mathrm{m} 1-\mathrm{m} 2$

0 present

1 absent

17. Hypoconulid on $\mathrm{m} 3$

0 expanded, forming a third lobe

1 not expanded

18. Entoconid on $\mathrm{m} 1-\mathrm{m} 2$

0 weak (does not reach lingual level of the metaconid)

1 developed (reaches lingual level of metaconid)

2 absent

19. Paralophid on $\mathrm{m} 1-\mathrm{m} 2$

0 level with or lingual to lingual border of metaconid 
1 labial to lingual border of metaconid

20. Entoconid on $\mathrm{m} 3$

0 developed and joined to hypolophid

1 incipient on the hypolophid

2 joined to hypolophulid

3 absent

21. Metaconid on $\mathrm{m} 2$

0 labial or level with paraconid and entoconid/hypoconulid

1 projects lingual to level of paraconid and entoconid/hypoconulid

22. Implantation of $\mathrm{c}-\mathrm{p} 2$

0 oblique

1 parallel to mandibular border

23. Trigonid valley on $\mathrm{p} 4$

0 larger than talonid valley

1 similar in size to talonid valley

24. Entoconid on $\mathrm{p} 4$

0 present

1 absent

25. Length of $\mathrm{m} 2$ *

0 small $(5-20 \mathrm{~mm})$

1 medium $(21-35 \mathrm{~mm})$

2 large (36-45 $\mathrm{mm})$

3 very large (more than $45 \mathrm{~mm}$ )

26. Position of coronal plane passing through infraorbital foramen *

0 anterior to M1

1 anterior to M2

2 anterior to M3

3 over M3

27. Snout in dorsal view *

0 premaxillae and maxillae separated sagittally

1 premaxillae sutured sagitally

2 premaxillae and maxillae sutured sagittally

28. Choana, rostral border (= posterior border of palate)

0 level with or anterior to posterior border

of M2

1 posterior to $\mathrm{M} 2$
29. Orbit, coronal plane passing through rostral border *

0 anterior to posterior border of M3

1 level with posterior border of M3

2 considerably posterior to M3 (equivalent to one tooth-length gap)

30. Sagittal crest

0 present

1 absent

31. Basioccipital, median crest

0 absent or vestigial

1 present

32. Skull shape

0 short and wide

1 long and narrow

33. Occipital condyles

0 protruding at level of nuchal crest in lateral view

1 not protruding at level of nuchal crest in lateral view

34. Odontoid notch

0 U-shaped

$1 \mathrm{~V}$-shaped 


\section{DAta Matrix}

Abbreviations: ? missing data; a polymorphic taxa (0 and 1$)$; b polymorphic taxa (2 and 3 ).

TAXA: The following outgroup taxa includes the scoring of different species of the same genus: Tricoelodus spp. (Tr. bicuspidatus and Tr. boliviensis); Coniopternium spp. (C. andinum and ?C. primitivum); Pternoconius spp. (Pt. polymorphoides and Pt. tournoueri) and Theosodon spp. (Th. lydekkeri, Th. lallemanti, Th. garrettorum, Th. fontanae, Th. gracilis, Th. patagonicum, and Th. karaikensis).

Changes In sCoring: Character 18, Xenorhinotherium bahiense, changed from 1 to 0 (entoconid does not reach the lingual level of the metaconid); character 4, Huayqueriana cristata, changed from 2 to ? (uncertain whether postorbital bar was complete; see text); character 9, Huayqueriana cristata, changed from 1 to 0 (small diastema in MLP 41-IV-29-4 between I3 and C).

Proadiantus excavatus
Tricoelodus spp.
Polymorphis lechei
Cramauchenia normalis
Coniopternium spp.
Pternoconius spp.
Theosodon spp.
Cullinia levis
Scalabrinitherium bravardi
Oxyodontherium zeballosi
Paranauchenia hystata
Paranauchenia denticulata
Promacrauchenia antiquua
Promacrauchenia calchaquiorum
Xenorhinotherium bahiense
Macrauchenia patachonica
Macrauchenopsis ensenadensis
Windhausenia delacroixi
Huayqueriana cristata
Huayqueriana cf. H. cristata

\begin{tabular}{|c|c|c|c|}
\hline ? ? ? ? ? ? ? 0 ? ? & ???? 100112 & 0 ?0a 0 ????? & ? ? ? ? \\
\hline ? ? ? ? ? ? 0 ? 1 & 0011100112 & $0 ? 010 ? ? ? ? ? ?$ & ? ? ? ? \\
\hline ? ? ? ? ? ? ? ? 1 & 0011000112 & 01110 ????? & ? ? ? ? \\
\hline 0000100001 & 0010101113 & $0 ? 11000 ? 00$ & 1000 \\
\hline ? ? ? ? ? ? ? 0 ? ? & $0 ? 10001110$ & $0 ? 010 ? ? ? ? ? ?$ & ? ? ? ? \\
\hline ? ? ? ? ? ? 0 ? ? & ????001112 & $01110 ? ? ? ? ?$ & ? ? ? ? \\
\hline 1000110001 & 0100001100 & a111111000 & 1111 \\
\hline ? ? ? ? ? ? ? 0 ? 0 & $0 ? 11001101$ & $0011 \mathrm{a} ? ? ? ? ?$ & ? ? ? ? \\
\hline $211 ? 110000$ & 1110001100 & $0 ? 11122101$ & $1 ? 01$ \\
\hline $211100 ? 010$ & 1110001103 & $0 ? 11 \mathrm{a} 2200 ?$ & $0 ? ? 0$ \\
\hline ? ? ? ? ? ? ? ? ? ? & $1 ? 1 ? 00 ? 00 ?$ & $11111 ? ? ? ? ?$ & ? ? ? ? \\
\hline ? ? ? ? ? ? ? 0 ? 0 & $1011 ? 01000$ & $1 ? ? 112 ? ? 0 ?$ & ? ? ? ? \\
\hline ?? 11000110 & 1101101001 & $001112 ? 101$ & 1101 \\
\hline $211 ? 000 ? 10$ & 1101 ? ? ? ?? ? & ?????22111 & $11 ?$ ? \\
\hline 2112011111 & 1101101103 & $001022 ? ? 21$ & ? 101 \\
\hline 2112111101 & 1011111203 & $00112 b 2121$ & $\begin{array}{llll}0 & 1 & 0 & 1\end{array}$ \\
\hline ? $11 ? 11 ? 100$ & 1101111203 & $00113 ? ? ? ? ?$ & ? ? ? ? \\
\hline ? 1 ? ? ? ? 1 ? ? ? & ? ? ? ? 10 ? 00 ? & ?0102????1 & ? ? 01 \\
\hline $211 ? 100 ? 0 ?$ & 1111 ? ? 1 ?? ? & $0 ? ? ? 1221 \mathrm{aa}$ & ? 1 ? ? \\
\hline $2111100 ? 0 ?$ & 11 ? ? ? ? ? ? ? & ?????22111 & 0110 \\
\hline
\end{tabular}




\section{APPENDIX 3}

Skull Length and Width of Temporalis Canal in Hindgut and Foregut Fermenters Measurements in $\mathrm{mm}$. Abbreviations: SL, length of skull (=condylobasal length); TS, width of temporalis canal (maximum distance between zygomatic arch and adjacent part of the braincase in horizontal plane); ${ }^{*}$, approximate measurement.

\begin{tabular}{|c|c|c|c|c|c|c|}
\hline Order & Family & Species & Collection number & $\begin{array}{l}\text { Digestive } \\
\text { physiology }\end{array}$ & SL & TS \\
\hline Artiodactyla & Giraffidae & Giraffa camelopardalis & MMB 12076 & Foregut & 550 & 45 \\
\hline Artiodactyla & Giraffidae & Okapia johnstoni & NMB 11009 & Foregut & 490 & 50 \\
\hline Artiodactyla & Giraffidae & Okapia johnstoni & NMB 11027 & Foregut & 480 & 48 \\
\hline Artiodactyla & Giraffidae & Okapia johnstoni & NMB 10778 & Foregut & 460 & 53 \\
\hline Artiodactyla & Giraffidae & Okapia johnstoni & NMB 10917 & Foregut & 470 & 50 \\
\hline Artiodactyla & Cervidae & Cervus elephus & ZMUZH 19206 & Foregut & 373 & 40 \\
\hline Artiodactyla & Cervidae & Cervus elephus & ZMUZH & Foregut & 320 & 35 \\
\hline Artiodactyla & Bovidae & Saiga tatarica & NMB 10132 & Foregut & 218 & 20 \\
\hline Artiodactyla & Bovidae & Saiga tatarica & NMB 10307 & Foregut & 217 & 16 \\
\hline Artiodactyla & Bovidae & Saiga tatarica & NMB 10065 & Foregut & 201 & 17 \\
\hline Artiodactyla & Bovidae & Saiga tatarica & NMB 1908 & Foregut & 235 & 20 \\
\hline Artiodactyla & Bovidae & Bubalus depressicornis & NMB 3268 & Foregut & 285 & 25 \\
\hline Artiodactyla & Bovidae & Bubalus depressicornis & NMB 2142 & Foregut & 293 & 29 \\
\hline Artiodactyla & Bovidae & Bubalus depressicornis & NMB 3001 & Foregut & 285 & 30 \\
\hline Artiodactyla & Camelidae & Camelus bactrianus & NMB 5918 & Hindgut & 450 & 70 \\
\hline Artiodactyla & Camelidae & Camelus bactrianus & NMB 5270 & Hindgut & 480 & 80 \\
\hline Artiodactyla & Hippopotamidae & Hexaprotodon liberiensis & NMB 10941 & Foregut & 330 & 60 \\
\hline Artiodactyla & Hippopotamidae & Hexaprotodon liberiensis & NMB 5297 & Foregut & 335 & 64 \\
\hline Artiodactyla & Hippopotamidae & Hippopotamus amphibius & NMB 2767 & Foregut & 650 & 120 \\
\hline Artiodactyla & Tayassuidae & Tayassu pecari & NMB 8074 & Foregut & 250 & 25 \\
\hline Artiodactyla & Tayassuidae & Tayassu pecari & NMB 8228 & Foregut & 240 & 25 \\
\hline Artiodactyla & Tayassuidae & Tayassu pecari & NMB 8418 & Foregut & 233 & 24 \\
\hline Artiodactyla & Tayassuidae & Tayassu pecari & NMB 3531 & Foregut & 207 & 28 \\
\hline Artiodactyla & Tayassuidae & Tayassu pecari & NMB 3894 & Foregut & 200 & 27 \\
\hline Artiodactyla & Tragulidae & Tragulus javanicus & NMB 3809 & Foregut & $89^{*}$ & 6.3 \\
\hline Artiodactyla & Tragulidae & Tragulus javanicus & NMB 3808 & Foregut & $85^{*}$ & 6 \\
\hline Artiodactyla & Tragulidae & Tragulus javanicus & NMB 6103 & Foregut & $89^{*}$ & 6.3 \\
\hline Artiodactyla & Tragulidae & Tragulus javanicus & NMB 3804 & Foregut & $87^{\star}$ & 6.8 \\
\hline Artiodactyla & Tragulidae & Tragulus javanicus & NMB 3795 & Foregut & $88.5^{*}$ & 7 \\
\hline Artiodactyla & Tragulidae & Tragulus javanicus & NMB 3803 & Foregut & $87^{*}$ & 9 \\
\hline Perissodactyla & Tapiridae & Tapirus terrestris & NMB 2689 & Hindgut & 350 & 40 \\
\hline Perissodactyla & Tapiridae & Tapirus terrestris & NMB 10437 & Hindgut & 383 & 43 \\
\hline Perissodactyla & Tapiridae & Tapirus terrestris & NMB 5691 & Hindgut & 390 & 50 \\
\hline Perissodactyla & Equidae & Equus grevyi & NMB 5463 & Hindgut & 560 & 45 \\
\hline Perissodactyla & Equidae & Equus grevyi & NMB 10873 & Hindgut & 555 & 40 \\
\hline Perissodactyla & Equidae & Equus grevyi & NMB 10876 & Hindgut & 570 & 45 \\
\hline Marsupialia & Macropodidae & Macropus giganteus & NMB 9437 & Foregut & 173 & 20 \\
\hline Marsupialia & Macropodidae & Macropus giganteus & NMB 3609 & Foregut & 168 & 18 \\
\hline Marsupialia & Macropodidae & Macropus giganteus & NMB 5453 & Foregut & 195 & 25 \\
\hline Marsupialia & Macropodidae & Macropus giganteus & NMB 7993 & Foregut & 171 & 23 \\
\hline Marsupialia & Vombatidae & Lasiorhinus latifrons & NMB 10851 & Hindgut & 167 & 30 \\
\hline Marsupialia & Vombatidae & Vombatus ursinus & NMB 4148 & Hindgut & 175 & 33 \\
\hline Marsupialia & Vombatidae & Vombatus ursinus & NMB 1929 & Hindgut & 179 & 34 \\
\hline
\end{tabular}




\title{
Scientific Publications of the American Museum of Natural History
}

AMERICAN MUSEUM NOVITATES

Bulletin of the American Museum of Natural History

Anthropological Papers of the American Museum of Natural History

\author{
Publications Committee \\ ROBERT S. VOSS, CHAIR \\ BOARD OF EDITORS \\ Jin Meng, Paleontology \\ LORENZO PRENDINI, INVERTEBRATE ZOOLOGY \\ Robert S. Voss, Vertebrate ZoOlogy \\ Peter M. Whiteley, Anthropology \\ MANAGING EDITOR \\ MARY KNIGHT
}

Submission procedures can be found at http://research.amnh.org/scipubs

All issues of Novitates and Bulletin are available on the web (http://digitallibrary.amnh. org/dspace). Order printed copies on the web from:

http://shop.amnh.org/a701/shop-by-category/books/scientific-publications.html

or via standard mail from:

American Museum of Natural History-Scientific Publications

Central Park West at 79th Street

New York, NY 10024

(0) This paper meets the requirements of ANSI/NISO Z39.48-1992 (permanence of paper).

On the cover: Artistic reconstruction of Huayqueriana, A Late Miocene macrauchenild litoptern from Argentina (PAINTING BY JORGE L. BLANCO, 2015). 